Illinois State University

ISU ReD: Research and eData

Theses and Dissertations

$10-5-2016$

\title{
Provenance Analysis Of Granite Cobbles In The Tiskilwa Till Using $\mathrm{U}-\mathrm{Pb}$ Geochronology
}

Paul Antone Meister

Illinois State University, pameist@ilstu.edu

Follow this and additional works at: https://ir.library.illinoisstate.edu/etd

Part of the Hydrology Commons

\section{Recommended Citation}

Meister, Paul Antone, "Provenance Analysis Of Granite Cobbles In The Tiskilwa Till Using U-Pb Geochronology" (2016). Theses and Dissertations. 624.

https://ir.library.illinoisstate.edu/etd/624

This Thesis is brought to you for free and open access by ISU ReD: Research and eData. It has been accepted for inclusion in Theses and Dissertations by an authorized administrator of ISU ReD: Research and eData. For more information, please contact ISUReD@ilstu.edu. 


\title{
PROVENANCE ANALYSIS OF GRANITE COBBLES IN THE TISKILWA TILL USING U-PB GEOCHRONOLOGY
}

\author{
Paul A Meister
}

\section{Pages}

$\mathrm{U}-\mathrm{Pb}$ isotopic ages were determined for zircons extracted from granitic and related rocks in the Tiskilwa till to determine their origin. Crystalline cobbles $(n=750)$ were collected at localities from each of the four of the sub-lobes of the terminal Wisconsin moraines. Two sites were chosen from the Decatur, Peoria, and Princeton sub-lobes with one sample taken from the Harvard sub-lobe. Each sample was then individually processed, the zircons handpicked $(\mathrm{n}=301)$, and geochronology conducted using LA-MC-ICPMS at the University of Arizona Laserchron Center. A KolmogorovSmirnov (K-S) statistical analysis show that all samples have identical zircon age spectra with the populations being dominated by Archean age (>2.5 Ga) grains and peak age being $2.7 \mathrm{Ga}$. The dominance of Archean grains indicate a source located in the Superior Province, with the Hudson Bay Terrane $(3.36-2.69 \mathrm{Ga})$ being the most likely source area for the granite clasts. In successfully utilizing granite clasts to determine provenance, this study could provide further insight into glacial transport systems.

KEYWORDS: Geochronology, Glacial Till, U-Pb, Zircon 
PROVENANCE ANALYSIS OF GRANITE COBBLES IN THE TISKILWA TILL USING U-PB GEOCHRONOLOGY

PAUL A. MEISTER

A Thesis Submitted in Partial Fulfillment of the Requirements for the Degree of

MASTER OF SCIENCE

Department of Geography-Geology

ILLINOIS STATE UNIVERSITY

2016 
Copyright 2016 Paul A Meister 
PROVENANCE ANALYSIS OF GRANITE COBBLES IN THE TISKILWA TILL USING U-PB GEOCHRONOLOGY

PAUL A. MEISTER

COMMITTEE MEMBERS:

David H. Malone, Chair

Eric W. Peterson

Lisa Tranel 


\section{ACKNOWLEDGMENTS}

The writer wishes to thank Dr. David Malone for his endless support during the research process as well as the assistance collecting samples and processing them. Dr. Eric Peterson, Dr. Lisa Tranel, and Dr. Tenley Banik for their invaluable input and support. Jason Thomason and Andy Stumpf for their input during the proposal process. Ellyn Rickels for the ideas and support during the research phase. Kasey Garber and Gwen Gates for their assistance processing the zircons. University of Arizona Laserchron center for being such gracious hosts during the data collecting process. Dr. John Craddock for his impromptu assistance in thesis defense and the field camp crew of 2016 for being such a willing and gracious audience. Lastly, his wife Heather for the tireless support and motivation to complete such an endeavor. I could not have done this without the support of each of you and for that I thank you!

P. A. M. 


\section{CONTENTS}

ACKNOWLEDGMENTS $\quad$ i

CONTENTS

TABLES $\quad$ iv

FIGURES

\section{CHAPTER}

I. THE PROBLEM AND ITS BACKGROUND 1

Introduction $\quad 1$

Location and Geologic Setting $\quad 6$

$\begin{array}{ll}\text { Research Objectives } & 7\end{array}$

$\begin{array}{ll}\text { Significance } & 7\end{array}$

$\begin{array}{ll}\text { Hypotheses } & 8\end{array}$

II. REVIEW OF RELATED LITERATURE 9

$\begin{array}{ll}\text { Glacial Till } & 9\end{array}$

$\begin{array}{ll}\text { Till Geochronology } & 10\end{array}$

$\begin{array}{ll}\text { Superior Province } & 11\end{array}$

III. RESEARCH DESIGN 13

$\begin{array}{ll}\text { Methods } & 13\end{array}$

IV. ANALYSIS OF THE DATA 22

Results $\quad 22$

Discussion 25 
V. SUMMARY, CONCLUSIONS, AND

RECOMMENDATIONS 28

$\begin{array}{lr}\text { Conclusion } & 28\end{array}$

$\begin{array}{ll}\text { REFERENCES } & 30\end{array}$

APPENDIX A: Frequency Plots for All Sampling Locations 35

APPENDIX B: Concordia Plots for All Sampling Locations 40

APPENDIX C: Complete Data For All Sampling Locations 44 


\section{TABLES}

Table $\quad$ Page

1. General rock type of all sample locations 15

2. K-S values with error 23 


\section{FIGURES}

$\begin{array}{ll}\text { Figure } & \text { Page }\end{array}$

1.1. Lithostratigraphy of Wisconsin and Hudson Episodes in Illinois (modified from Hansel and Johnson, 1996).

1.2. Map of Wisconsinan age moraines in Illinois with shading indicating Tiskilwa formation exposed at the surface (from Hansel and Johnson, 1996). 3

1.3. Diagram of the Laurentide ice sheet with line work showing positions of the ice sheet and arrow indicating ide flow direction (from Leverett and Taylor, 1915).

1.4. Diagram showing ice flow directions during Wisconsin Episode (Johnson et. al., 1986).

2.1. Major tectonic terrains of North America (Percival et al. 2012) with inset showing subprovince types of the Superior Province showing general locations of major terranes and rock types (modified from Card, 1990; Card and Paulsen,1998).

3.1. Map showing sampling locations. Red shading indicates Tiskilwa Till exposed at the surface (from Hansel and Johnson, 1996).

3.2a. Total Clasts from one sample site

3.2b. Cobble-size clast

3.3a. Chipmunk Crusher

3.3b. Disk Mill

3.4a. Panned Concentrate

3.4b. Zircon in microscope view

3.5. Mounted samples showing sample grains and the three standards used. The darker grains are impurities which were not analyzed. 
4.1. Cumulative probability plot for all sample locations with outline showing age range of Hudson Bay Terrane $(3.36-2.69 \mathrm{Ga})$.

4.2. Frequency plots of all sample locations

4.3. Laurentide ice sheet reconstruction showing ice domes from Dyke and Prest, (1987). Inset showing Superior Province from Card and Paulsen (1998). 


\section{CHAPTER I}

\section{THE PROBLEM AND ITS BACKGROUND}

\section{INTRODUCTION}

Glacial deposits in Illinois have been recognized since the late 1800's as forming landforms that are important for agriculture and natural resources such as sand and gravel deposits. The multiple glaciation events forming these landforms have been noted as far back as 1878 when T.C. Chamberlin mapped them, and described deposits of different ages (Chamberlin, 1878). With the recognition of multiple glacial events, it was determined that during the Wisconsin Episode a till, classified as the Tiskilwa Formation (Hansel and Johnson, 1996) (Figure 1.1), is one of the thickest tills in Illinois (Wickham et. al., 1988). Of the four Wedron Formations, the Tiskilwa is the thickest and most areal extensive (Hansel and Johnson, 1996). The Tiskilwa Formation deposition began as the Laurentide ice sheet entered Illinois 29,000 YB (Curry et al., 2011). During the subsequent advancement and retreat of the ice sheet, the Tiskilwa Formation was

deposited in outcrops located in the outermost moraines of the Harvard, Princeton, Peoria, and Decatur sublobes (Figure 1.2). In these areas, the till can reach thicknesses of more than $60 \mathrm{~m}(200 \mathrm{ft})$ (Wickham et al., 1988). 


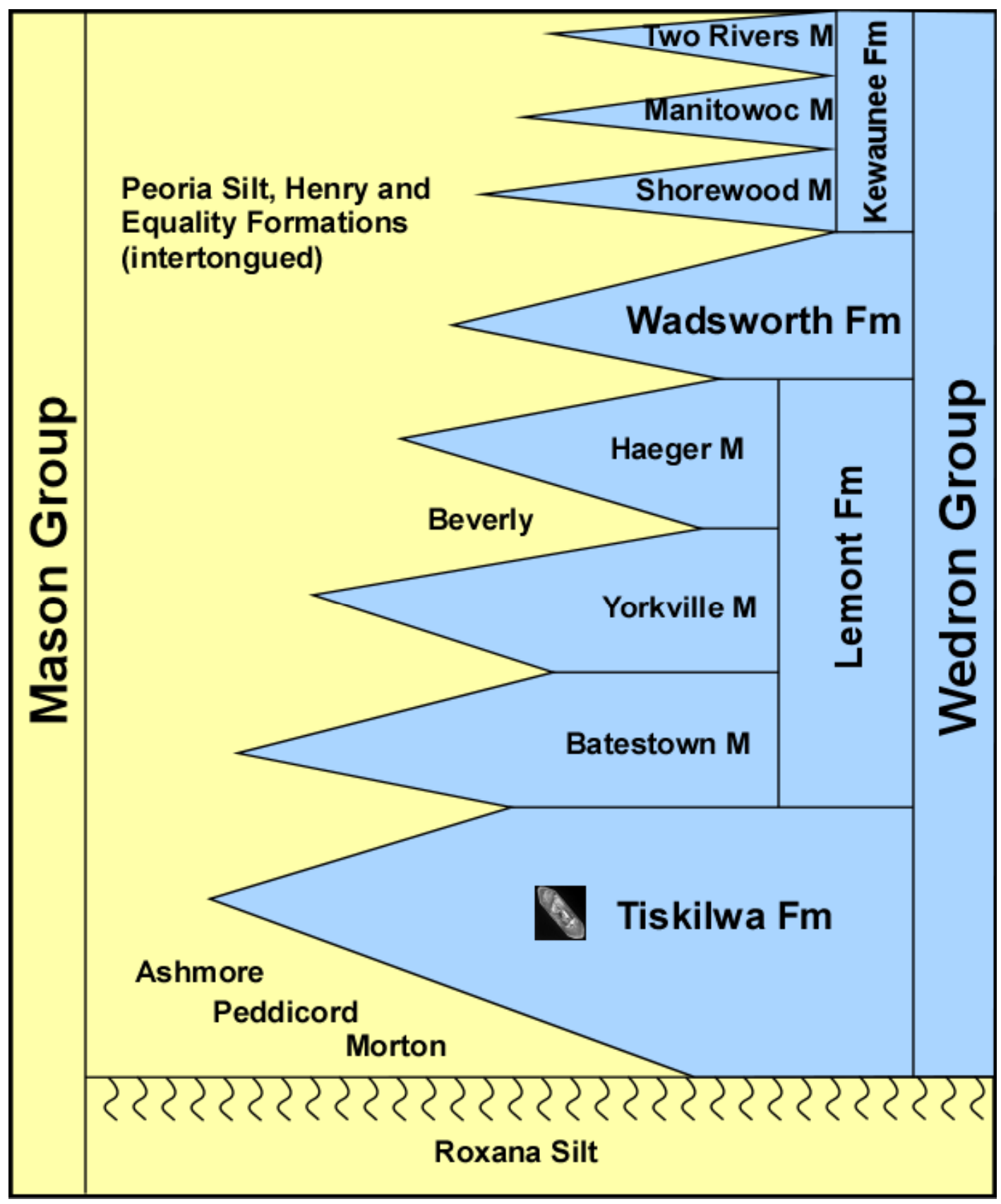

Figure 1.1: Lithostratigraphy of Wisconsin and Hudson Episodes in Illinois (modified from Hansel and Johnson, 1996) 


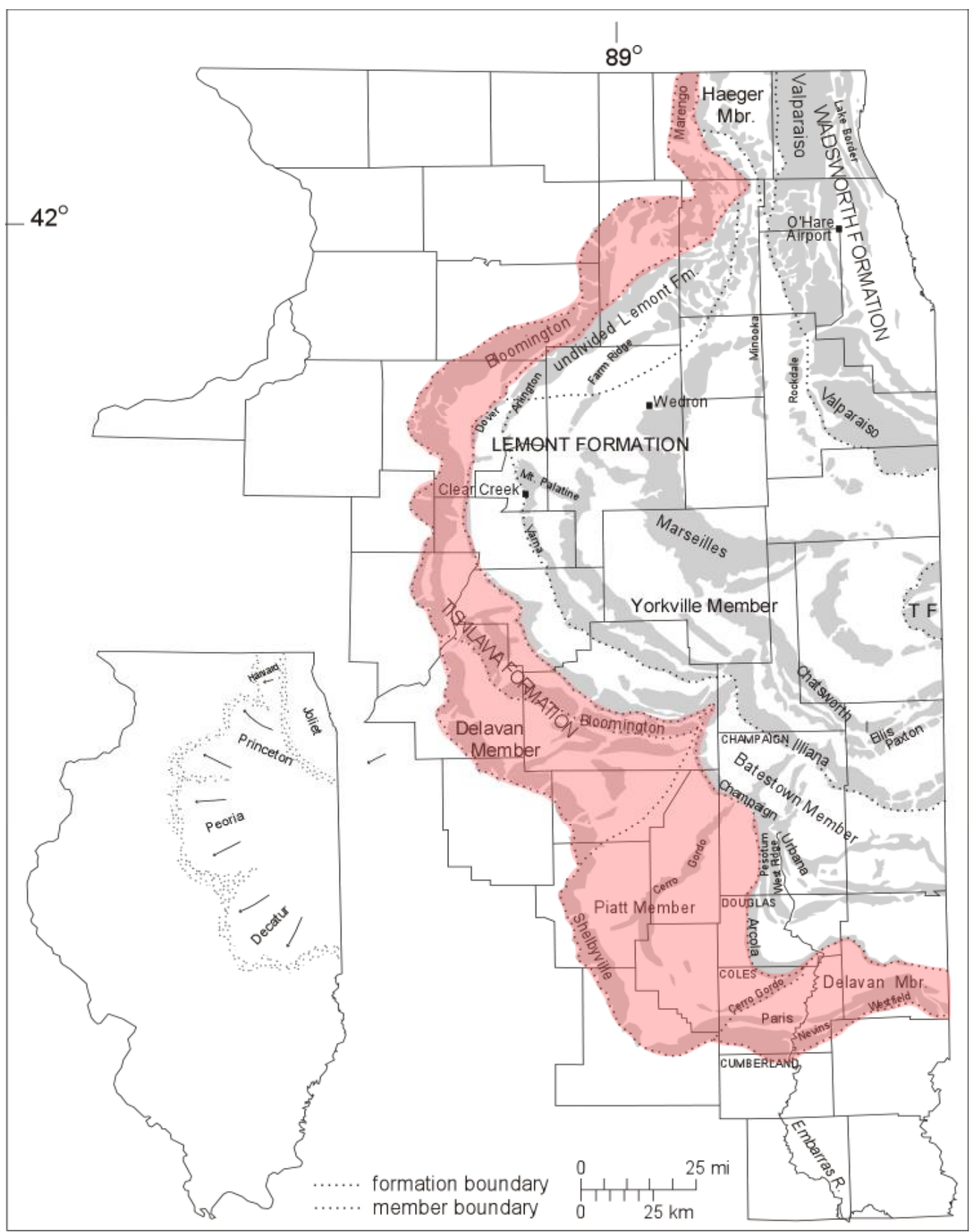

Figure 1.2: Map of Wisconsinan age moraines in Illinois with shading indicating Tiskilwa formation exposed at the surface (from Hansel and Johnson, 1996). 
Leverett and Tayor (1915) were the first to recognize that the Tiskilwa and other Tills deposited during the Wisconsin Episode by an ice lobe that flowed through Lake Michigan. Their interpretation was based on the lobate shape of glacial moraines that parallel the current lake shore to the south and west. Hansel and Johnson (1992) determined that the Tiskilwa was deposited between 29,000-23,000 YBP during the Michigan Subepisode.

Later work by Willman and Frye (1970) divided the Lake Michigan into the Peoria and Decatur sublobes as "interlobate" in nature with the ice sheet that deposited the Peoria sub-lobe having a northerly source and the ice sheet that deposited the Decatur sub-lobe as having a more easterly source. Bleuer and McKay (1975) and Moore (1981) support the hypothesis of Leverett and Taylor of a more northerly source (Johnson et. al., 1996). Johnson et al. (1986) used garnet-epidote ratios to determine that the Decatur and Peoria sub-lobes contained ratios that corresponded to the Southern and Superior Provinces (Figure 1.4). 


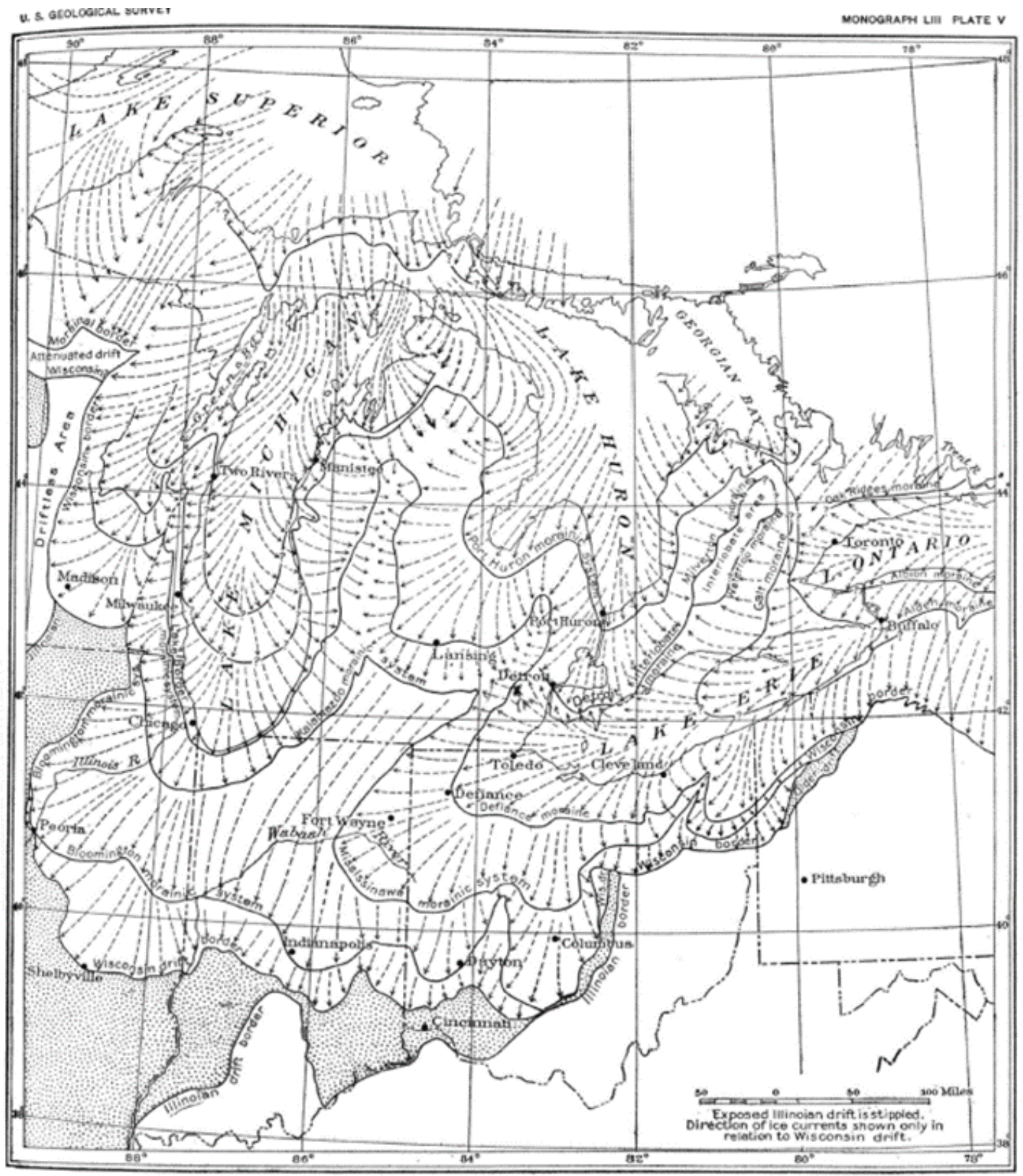

Figure 1.3: Diagram of the Laurentide ice sheet with line work showing positions of the ice sheet and arrow indicating ide flow direction (from Leverett and Taylor, 1915). 


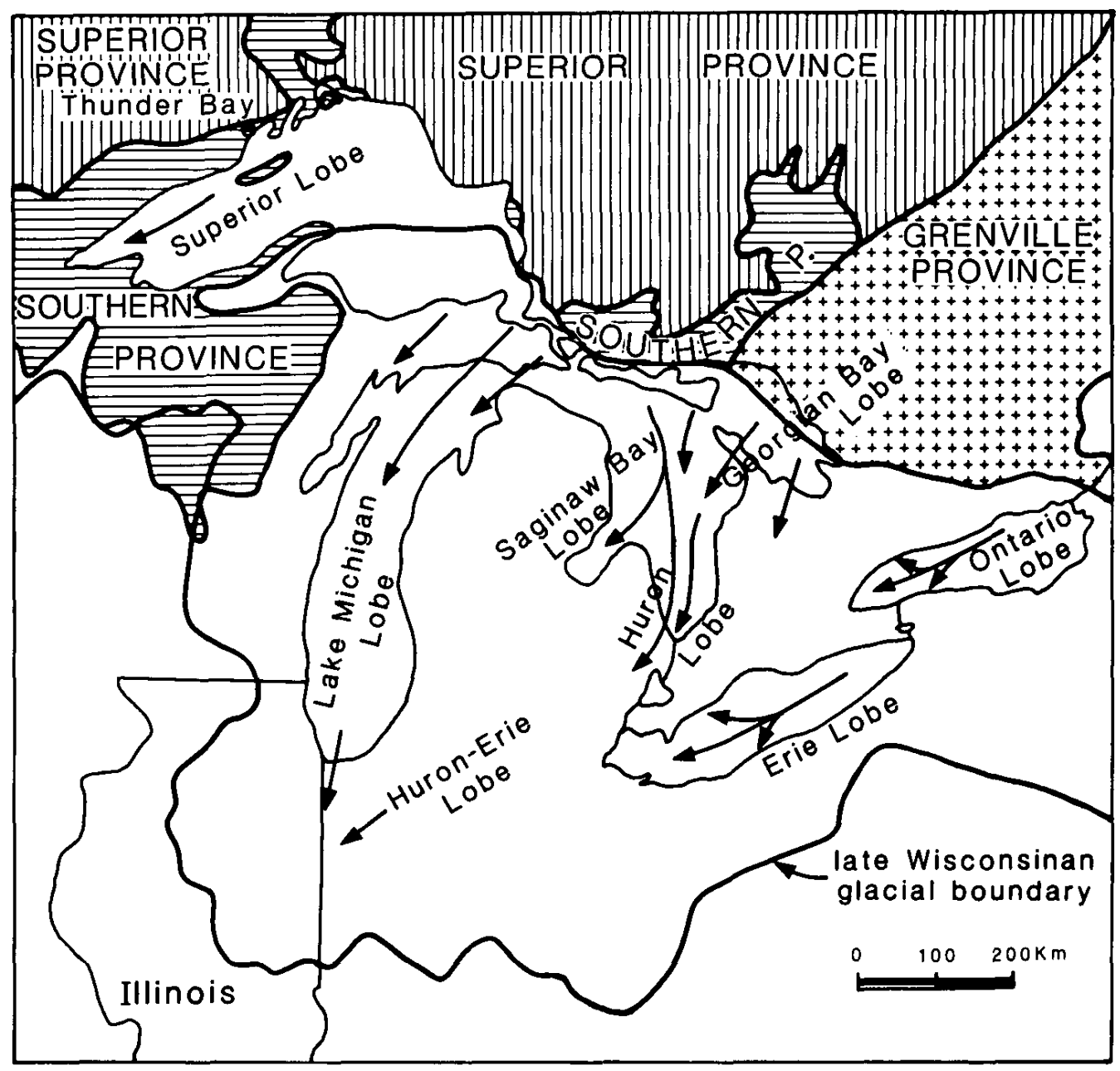

Figure 1.4: Diagram showing ice flow directions during Wisconsin Episode (Johnson et. al., 1986).

\section{LOCATION AND GEOLOGIC SETTING}

This study was conducted over a large area of Illinois, at sites located on terminal moraines of four of the five major Wisconsin Episode sublobes of the Laurentide Ice Sheet (Figure 1.2). The sites are located in the Decatur sublobe to the south, the Peoria sublobe to the west, the Princeton sub-lobe to the northwest, and the Harvard sublobe to the north. To the east, the Huron-Erie sublobe was not sampled because glaciers flowing through the Huron and Erie lakes basins had a different source area and did not deposit 
the Tiskilwa Formation till. The Joliet subloabe was not sampled due to the lack of till outcrop at the surface. The Laurentide ice sheet transported eroded bedrock that could originate from sources in the Superior, Southern, or Grenville structural provinces. At all the sites, the Tiskilwa Formation till was exposed at the land surface.

\section{RESEARCH OBJECTIVES}

The objective of this project is to determine if geochronology of glacial erratics from an end moraine on a regional scale can be successful in determining provenance. A second objective of the project is to compare ages obtained regionally with ages obtained from granite cobbles in a recessional moraine of the Peoria sublobe (Rickels, 2016).

\section{SIGNIFICANCE}

The significance of this study is two-fold. First and foremost, a regional isotopic provenance study on glacial till using granite cobbles has not been performed in Illinois. In fact, a regional study on granite clasts in glacial till at this scope has never been performed in the world. In many studies on glaciated terrain, only zircons from a few clasts have been dated to determine till provenance (e.g., Plouffe et al., 2011; Doornbos et al., 2009). By analyzing the age of several hundred clasts, the reliability of the dating will be drastically improved by reducing sampling bias. The increased sample size will reduce potential sampling error as well as increasing the data set acquired. Secondly, obtaining precise ages on zircons will lead to a refinement of sedimentary provenance for the Tiskilwa till. 


\section{HYPOTHESES}

This project is designed to test the application of $\mathrm{U} / \mathrm{Pb}$ geochronology on granite

clasts for determining the provenance of a glacial till. The following hypotheses will be examined through the research.

1. $\mathrm{U} / \mathrm{Pb}$ isotopes dating can provide ages of granite clasts in the Tiskilwa Formation till and thus lead to a refinement in source area determination.

2. $\mathrm{U} / \mathrm{Pb}$ isotope dates may be used to distinguish between specific glacial lobes of the Wisconsin Episode and therefore could lead to revision of ice flow pathways. 


\section{CHAPTER II}

\section{REVIEW OF RELATED LITERATURE}

\section{GLACIAL TILL}

Glacial till provenance has long been studied to further refine and constrain the geologic history and to determine the source areas for "exotic" or mineralized material. Various techniques have been used to determine the abundance of indicator minerals (McClenaghan et al. 2000; Averill 2001) and garnet and epidote grains (Gwyn and Dreimanis, 1979) in till for provenance studies. Others have used pebble lithologies to identify the source area of the till (e.g., Prest et al., 2000). Still others have used variance in matrix textures and composition (e.g., Lusardi et al., 2011) and shape of mineral grains (Dreimanis and Vagners, 1971). These techniques can be used to identify a provenance region, however, they do not provide an emplacement or crystallization age of the source rock. More recently, $\mathrm{U} / \mathrm{Pb}$ isotopes from zircons and ${ }^{40} \mathrm{Ar} /{ }^{39} \mathrm{Ar}$ isotopes from feldspars have been used to determine ages of crystalline glacial erratics (e.g., Doornbos et al. 2009; Roy et al. 2007). Using detrital zircons to determine provenance builds on the extensive use of the isotopes to date bedrock from both detrital sources (Malone et al., 2014a) and in-situ sources (Malone et al., 2014b) to successfully determine provenance. Doornbos et al. (2009) were successful in determining precise ages of glacial erratics transported across the western Arctic Archipelago of Canada using only eight erratics with an in situ method. 
A combination of methodologies, including $\mathrm{U} / \mathrm{Pb}$ isotopes with geophysical studies have also been used to trace mineralized erratics to the source bedrock (Plouffe et.al., 2011).

\section{Till Geochronology}

Methods for till geochronology have included sampling sand size particles with mixed results. One such study performed recently by Licht et al. (2013) was successful in gathering $\mathrm{U} / \mathrm{Pb}$ ages on till in Antarctica; however, they acknowledge that by collecting sand size particles there may have been recycling from previously exposed unsuccessful in using sand size particles to distinguish provenance.

Utilizing granite cobbles will lead to a more precise provenance on till. Sand sized particles likely contain detrital zircons from many sources while crystalline rocks would contain zircons that would have formed at the time of the rock formation. In fact, Zimmerman et al. (2015) show that sedimentary processes coupled with different transport mechanisms can produce large differences in provenance signals within a single sedimentary succession. Using only granite clasts will eliminate the difference in provenance signals. 


\section{SUPERIOR PROVINCE}

Within the heart of the North American continent lies the Superior Province. Comprising a total area of $1.4 \times 10^{6} \mathrm{~km}^{2}$, the Superior Province is the largest craton on Earth (Percival et al., 2012). The Superior Province consists largely of Archean rocks >2500 Ma (Card and Ciesielski, 1986) which can be subdivided into four regions (Figure

2.1). The four regions are the western, central, moyen-nord. and northeastern Superior regions (Percival et al., 2012). Located within the western region, the Hudson Bay Terrane is comprised of plutonic rocks with ages ranging from 3.36 to $2.69 \mathrm{Ga}$ (Percival, 2007). Further subdivision of the Hudson Bay Terrane yields the Minto Block. The Minto Block underwent a major episode of igneous activity and crustal reworking from approximately $2.74-2.70 \mathrm{Ga}$ (Milidragovic et al., 2014). At this time, the proto-cratonic crust, largely composed of tonalite, trondhjemite, granodiorite (TTG) plutonic suites, underwent largescale melting giving rise to voluminous granite, granodiorite, monzogranite (GGM) and pyroxene-bearing intermediate to felsic plutonic rocks (Milidragovic et al., 2014). 


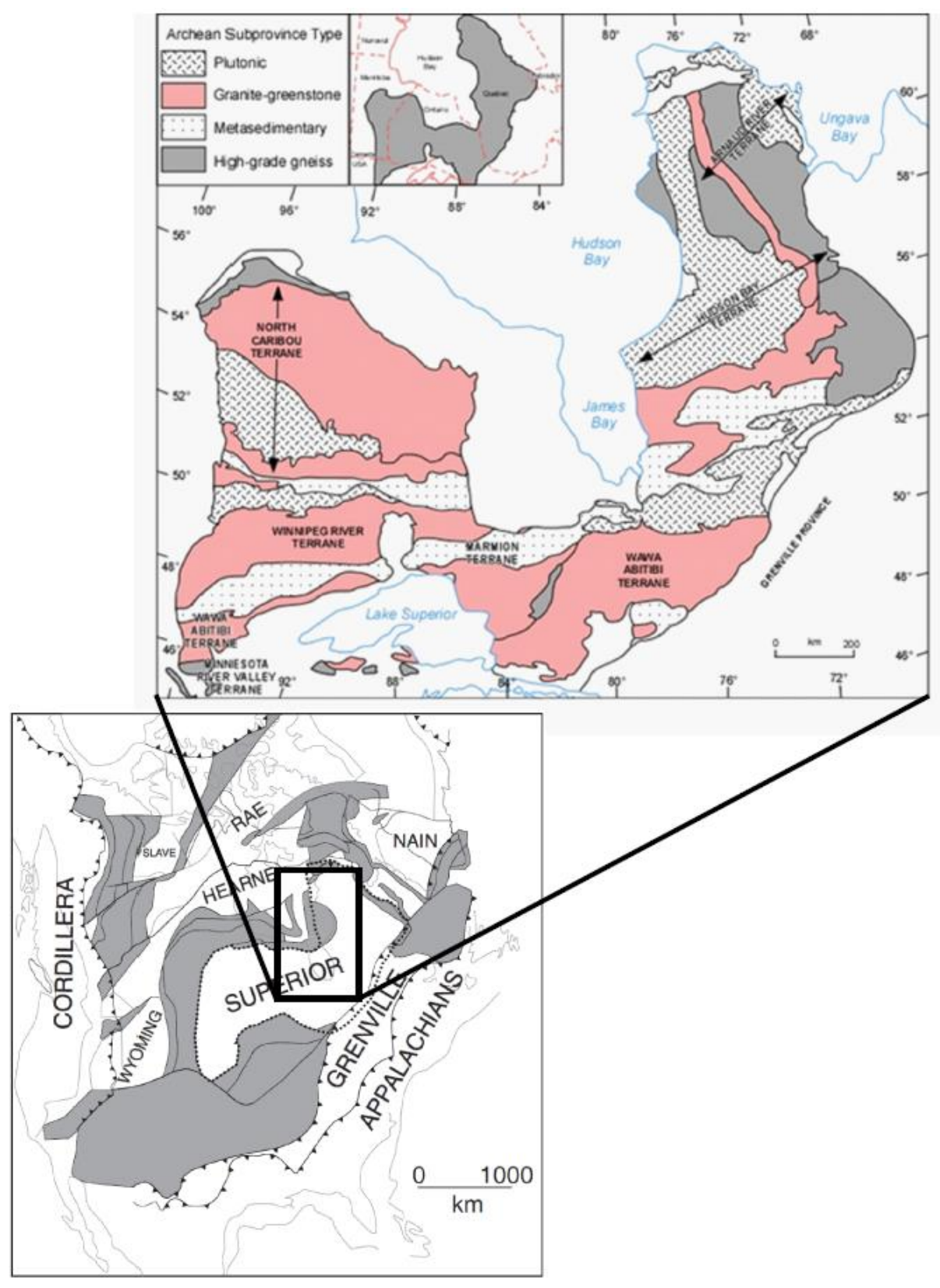

Figure 2.1: Major tectonic terrains of North America (Percival et al. 2012) with inset showing subprovince types of the Superior Province showing general locations of major terranes and rock types (modified from Card, 1990; Card and Paulsen, 1998). 


\section{CHAPTER III \\ RESEARCH DESIGN}

\section{METHODS}

In total 70-120 cobble size clasts were collected from two sites each in the

Decatur, Peoria, and Princeton sub-lobes, and one site in the Harvard sub lobe (Figure

\section{1).}

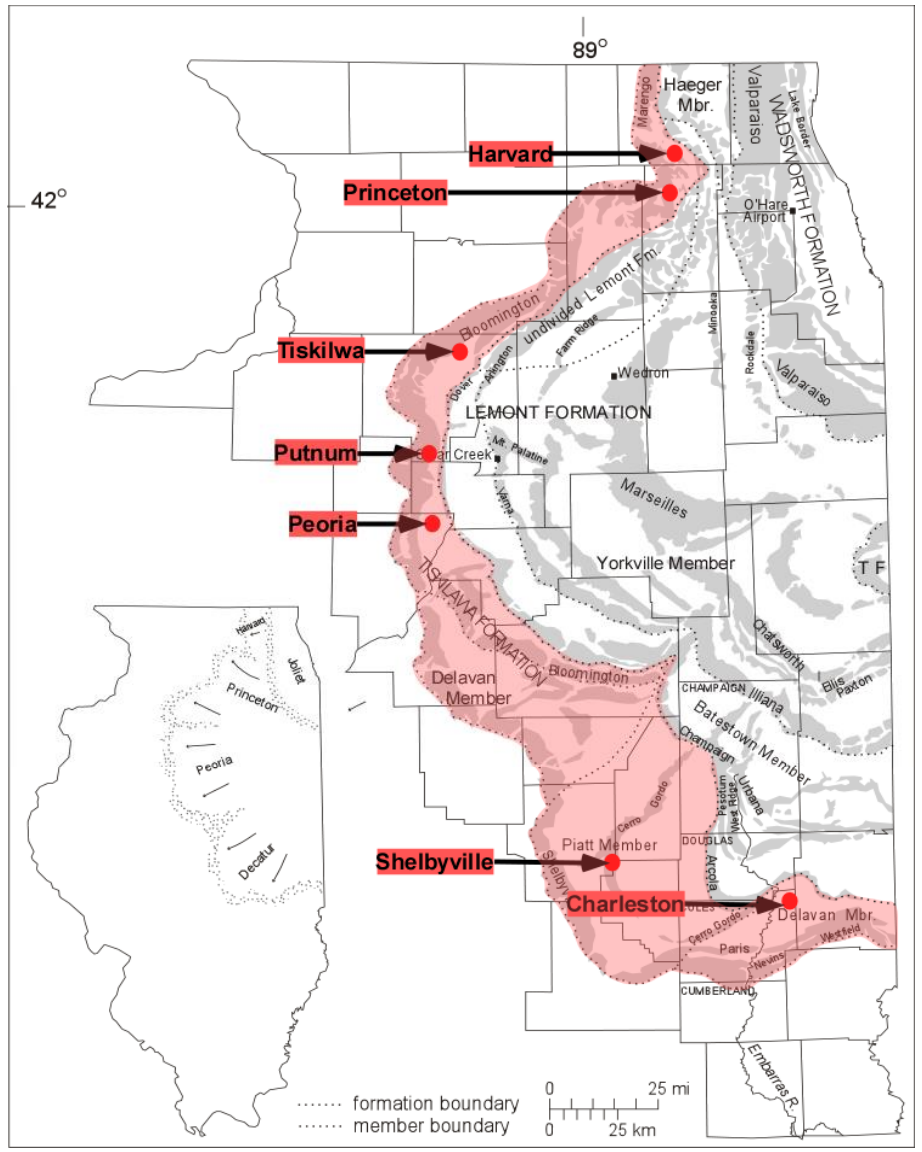

Figure 3.1: Map showing sampling locations. Red shading indicates Tiskilwa Till exposed at the surface (from Hansel and Johnson, 1996). 
In total, 750 clasts were collected for sampling zircons. Only one sample was collected from the Harvard sub-lobe due to the smaller area in comparison to the other lobes. No samples were collected from the Joliet and Huron-Erie sublobes due to lack of outcrop and size of the lobe, respectively. The distribution of sites was determined on the accessibility of outcrops. Individual samples were photographed and the maximum diameter of each clast measured (Figures 3.2a, b).

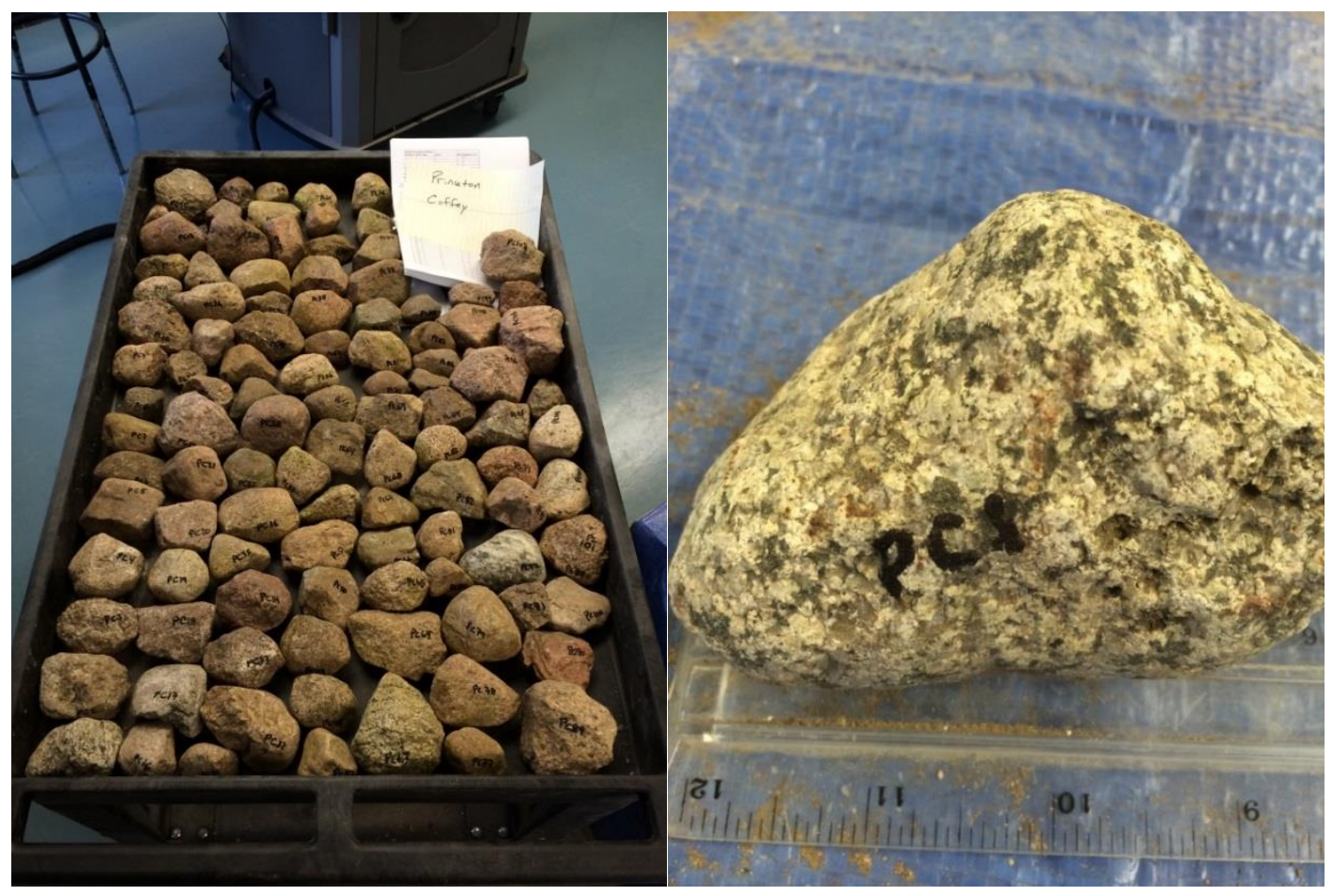

Figure 3.2a: Total Clasts from one sample site

Figure 3.2b: Cobble-size clast

The general rock type of each clast was recorded and any non-crystalline rock clasts rejected (Table 1). The non-crystalline rocks were rejected to eliminate possible detrital zircons that were recycled from other sources. Each sample was crushed individually with a chipmunk crusher (Figure 3.3a) and then ground with a disc mill (Figure 3.3b). 
TABLE 1: GENERAL ROCK TYPE FOR ALL SAMPLE LOCATIONS. (NOTE ONLEY CRYSALLINE ROCKS WERE USED FOR ANALYSIS).

\begin{tabular}{|c|c|c|c|c|c|}
\hline Peoria & & Princeton & & Putnum & \\
\hline Total Clasts & 123 & Total Clasts & 107 & Total Clasts & 110 \\
\hline Tota Clasts Used & 120 & Tota Clasts Used & 105 & Tota Clasts Used & 108 \\
\hline Granite & 91 & Granite & 85 & Granite & 79 \\
\hline Granodiorite & 21 & Granodiorite & 3 & Granodiorite & 13 \\
\hline Diorite & 5 & Diorite & 17 & Diorite & 13 \\
\hline Rhyolite Porphry & 3 & Quartzite & 2 & Rhyolite Porphry & 2 \\
\hline Carbonate & 3 & & & Quartzite & 3 \\
\hline Shelbyville & & Harvard & & Charleston & \\
\hline Total Clasts & 95 & Total Clasts & 110 & Total Clasts & 108 \\
\hline Tota Clasts Used & 93 & Tota Clasts Used & 105 & Tota Clasts Used & 108 \\
\hline Granite & 62 & Granite & 93 & Granite & 71 \\
\hline Granodiorite & 12 & Granodiorite & 8 & Granodiorite & 24 \\
\hline Diorite & 17 & Diorite & 3 & Diorite & 11 \\
\hline Rhyolite & 1 & Quartize & 5 & Syenite & 1 \\
\hline Carbonate & 1 & MonzoDiorite & 1 & Amphibolite Schist & 1 \\
\hline Quartzite & 1 & & & & \\
\hline Amphibolite & 1 & & & & \\
\hline Tiskilwa & & All Sites & & & \\
\hline Total Clasts & 97 & Total & 750 & & \\
\hline Tota Clasts Used & 95 & Total Used & 626 & & \\
\hline Granite & 52 & Granite & 533 & & \\
\hline Granodiorite & 16 & Granodiorite & 97 & & \\
\hline Diorite & 26 & Diorite & 92 & & \\
\hline Rhyolite Porphry & 1 & Rhyolite Porpyry & 6 & & \\
\hline \multirow[t]{7}{*}{ Carbonate } & 2 & Rhyolite & 1 & & \\
\hline & & Carbonate & 6 & & \\
\hline & & Syenite & 1 & & \\
\hline & & Amphibolite Schist & 1 & & \\
\hline & & Amphibolite & 1 & & \\
\hline & & MonzoDiorite & 1 & & \\
\hline & & Quartzite & 11 & & \\
\hline
\end{tabular}




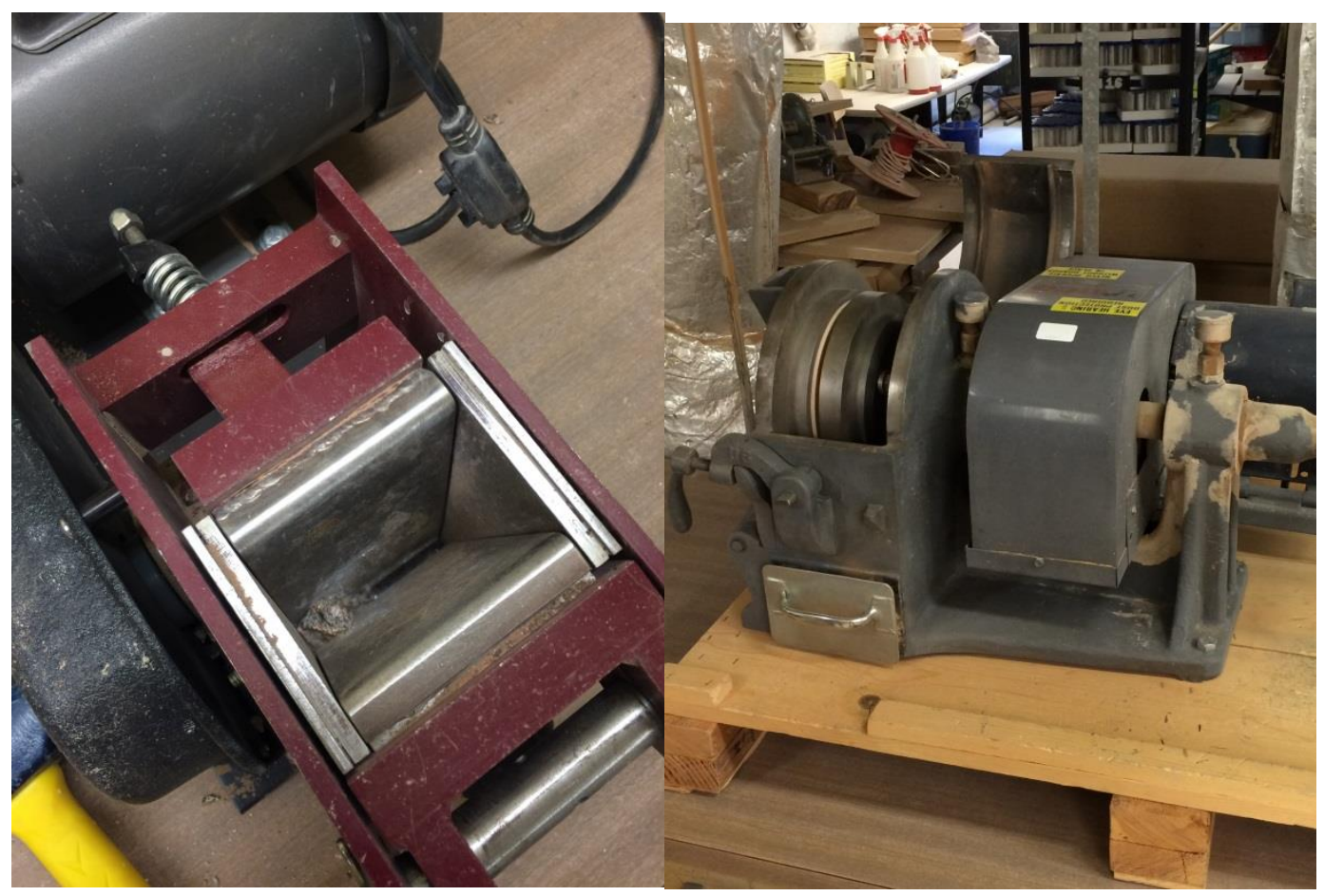

Figure 3.3a: Chipmunk Crusher

Figure 3.3b: Disk Mill

In order to avoid sampling bias, each sample was panned to a concentrate of heavy

minerals (Figure 3.4a), dried, and one zircon selected from each concentrate using a binocular microscope (Figure 3.4b). When possible the first zircon viewed in the microscope aperture was selected for analysis. 


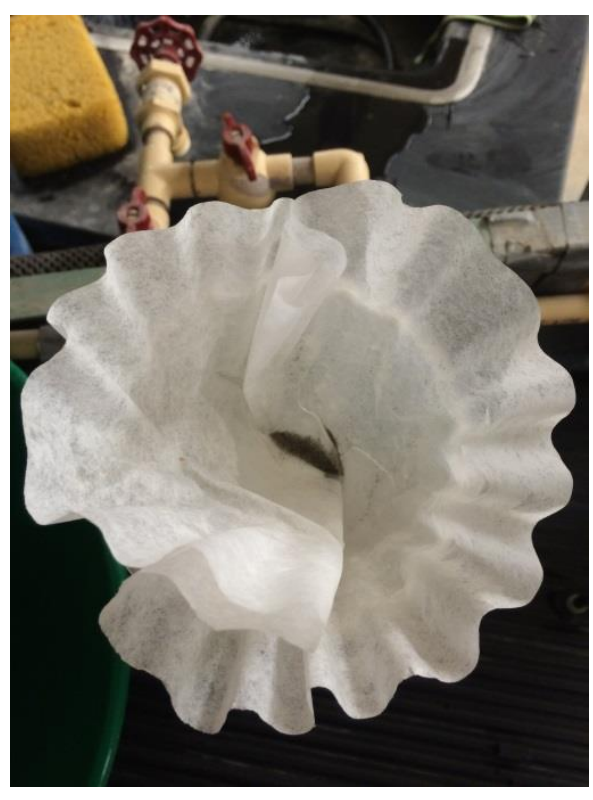

Figure 3.4a: Panned Concentrate

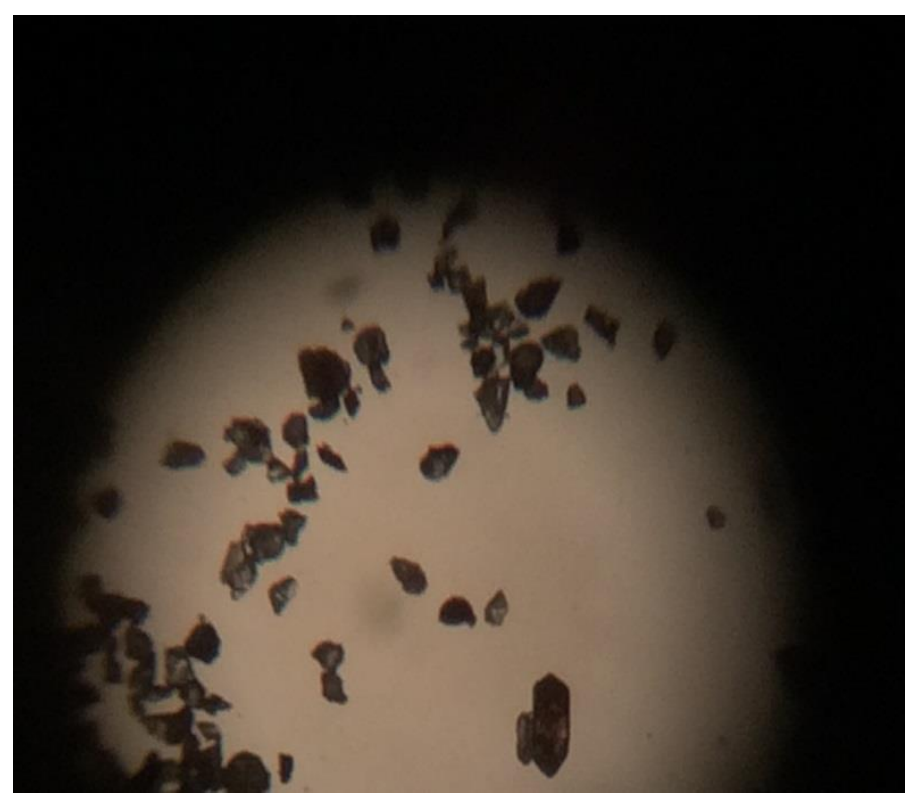

Figure 3.4b: Zircon in microscope view

Not only did this procedure counter bias, especially for samples that are more abundant in zircons, it also was more cost effective since heavy liquids and magnetic separation were not needed. Once the zircons were sampled, each sample site suite was placed into a vial and shipped to the University of Arizona Laserchron Center where they were mounted onto 1-inch diameter epoxy pucks along with fragments of three standards The standards used are 1) Sri Lanka zircon, calibrated in-house by isotope dilutionthermal ionization (ID-TIMS) (Gehrels et al., 2008); 2) FC1 zircons from the Duluth Gabbro complex dated at $1099 \pm 2 \mathrm{Ma}$ (Paces and Miller, 1993; Schmitz et al., 2003); and 3) R33 zircon crystals yielding an age of $419.3 \pm 0.4 \mathrm{Ma}$ (Black et al., 2004). 
These pucks were then polished to half thickness to expose the interior of the grains and cleaned. Cathodoluminescence (CL) images were taken for each mount to help in determining the location of laser pits and to identify zircon from other mineral grains (Figure 3.5).

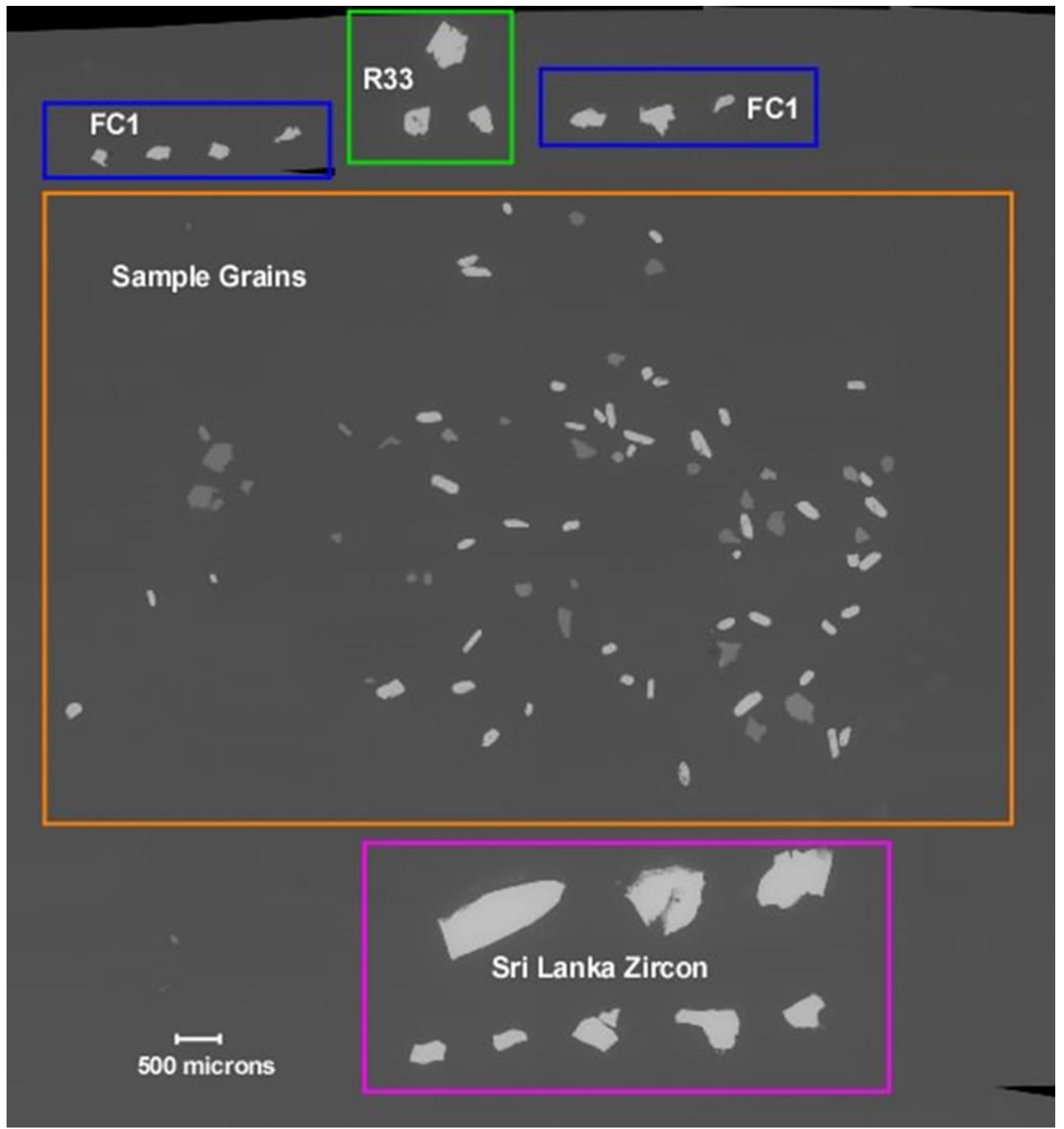

Figure 3.5: Mounted samples showing sample grains and the three standards used. The darker grains are impurities which were not analyzed. 
$\mathrm{U}-\mathrm{Pb}$ geochronology of zircons was conducted by laser ablation multicollector inductively coupled plasma mass spectrometry (LA-MC-ICPMS) at the Arizona LaserChron Center (Gehrels et al., 2008). The analyses involve ablation of zircon with a Photon Machines Analyte G2 Excimer laser using a spot diameter of 30 microns. The ablated material is carried in helium into the plasma source of a Nu HR ICPMS, which is equipped with a flight tube of sufficient width that $\mathrm{U}$, Th, and $\mathrm{Pb}$ isotopes are measured simultaneously. All measurements are made in static mode, using Faraday detectors with $3 \times 10^{\prime \prime}$ ohm resistors for $\approx \mathrm{U}, \cdots \mathrm{Th}, \cdots \mathrm{Pb}-m \mathrm{~Pb}$, and discrete dynode ion counters for $\cdots \mathrm{Pb}$ and ${ }^{20} \mathrm{Hg}$. Ion yields are $\sim 0.8 \mathrm{mv}$ per ppm. Each analysis consists of one 15 -second integration on peaks with the laser off (for backgrounds), 15 one-second integrations with the laser firing, and a 30 second delay to purge the previous sample and prepare for the next analysis. The ablation pit is $\sim 15$ microns in depth.

For each analysis, the errors in determining $\cdots \mathrm{Pb} / \cdots \mathrm{U}$ and $\cdots \mathrm{Pb} / \cdots \mathrm{Pb}$ result in a measurement error of $\sim 1-2 \%$ (at 2-sigma level) in the $\mathrm{mb} / \approx \mathrm{U}$ age. The errors in measurement of $m \mathrm{~Pb} / m \mathrm{~Pb}$ and $m \mathrm{~Pb} / \cdots \mathrm{Pb}$ also result in $\sim 1-2 \%$ (at 2-sigma level) uncertainty in age for grains that are $>1.0 \mathrm{Ga}$, but are substantially larger for younger grains due to low intensity of the $\mathrm{Pb}$ signal. For most analyses, the cross-over in precision of $m \mathrm{~Pb} /=\mathrm{U}$ and $\mathrm{Pb} / \mathrm{Pb}$ ages occurs at $\sim 1.0 \mathrm{Ga}$.

${ }^{20} \mathrm{Hg}$ interference with ${ }^{204} \mathrm{~Pb}$ is accounted for measurement of ${ }^{20} \mathrm{Hg}$ during laser ablation and subtraction of ${ }^{20} \mathrm{Hg}$ according to the natural ${ }^{200} \mathrm{Hg} /{ }^{204} \mathrm{Hg}$ of 4.35 . This $\mathrm{Hg}$ is correction is not significant for most analyses because our $\mathrm{Hg}$ backgrounds are low (generally $\sim 150 \mathrm{cps}$ at mass 204 ). 
Common $\mathrm{Pb}$ correction is accomplished by using the $\mathrm{Hg}$-corrected $\mathrm{Pb}$ and assuming an initial $\mathrm{Pb}$ composition from Stacey and Kramers (1975). Uncertainties of 1.5 for $\cdots \mathrm{Pb} / \mathrm{mb}$ and 0.3 for ${ }^{m} \mathrm{~Pb} / \mathrm{Pb}$ are applied to these compositional values based on the variation in $\mathrm{Pb}$ isotopic composition in modern crystal rocks.

Inter-element fractionation of $\mathrm{Pb} / \mathrm{U}$ is generally $\sim 5 \%$, whereas apparent fractionation of $\mathrm{Pb}$ isotopes is generally $<0.2 \%$. In-run analysis of fragments of a large zircon crystal (generally every fifth measurement) with known age of 563.5 $\pm 3.2 \mathrm{Ma}(2-$ sigma error) is used to correct for this fractionation. The uncertainty resulting from the calibration correction is generally 1-2\% (2-sigma) for both $2 \mathrm{~Pb} / \mathrm{Pb}$ and $\cdots \mathrm{Pb} / \mathrm{U}$ ages. Concentrations of $\mathrm{U}$ and Th are calibrated relative to our Sri Lanka zircon, which contains $\sim 518 \mathrm{ppm}$ of $\mathrm{U}$ and $68 \mathrm{ppm}$ Th.

The analytical data are reported in Appendix C. Uncertainties shown in these tables are at the 1-sigma level, and include only measurement errors. Analyses that are $>20 \%$ discordant (by comparison of $\cdots \mathrm{Pb} / \cdots \mathrm{U}$ and $\cdots \mathrm{Pb} / \mathrm{Pb}$ ages) or $>5 \%$ reverse discordant are not considered further.

The resulting interpreted ages are shown on $\mathrm{Pb} / \mathrm{U}$ concordia diagrams and weighted mean diagrams using the routines in Isoplot (Ludwig, 2008). The weighted mean diagrams show the weighted mean (weighting according to the square of the internal uncertainties), the uncertainty of the weighted mean, the external (systematic) uncertainty that corresponds to the ages used, the final uncertainty of the age (determined by quadratic addition of the weighted mean and external uncertainties), and the MSWD of the data set. 
The data reduction was completed using a fully automated Excel spreadsheet and data imported from Isoprobe files (Gehrels et al, 2008). All corrections and calculations were performed in the database, including ages, uncertainties, and error correlations. Analyses that were $>10 \%$ discordant or $>5 \%$ reversely discordant were excluded. The "best ages" (those with the smallest error of the three ages generated) were used to determine crystallization ages of the zircons, and relative probability density plots were constructed with these ages using Isoplot (Ludwig, 2008). The ages acquired by the LAMC-ICPMS data was compared to up-ice bedrock crystallization ages determined by Card (1990), Percival and Easton (2007), Lasalle et. al. (2014) and Raharimahefa et. al. (2014). 


\section{CHAPTER IV \\ ANALYSIS OF THE DATA}

\section{RESULTS}

In total 301 zircons were analyzed for the study. Zircons that were $>10 \%$ discordant and $>5 \%$ reverse discordant were not used in the data analysis. The sample population is dominated by Archean $(2.5-3 \mathrm{Ga})$ age zircons with the peak age being $2703 \mathrm{Ma}$. Concordia diagrams were also constructed for the samples, all showing similar Concordia ages. All detailed zircon geochronology data are found in Appendix C. A Kolmogorov-Smirnov (K-S) test was also applied to the data comparing the groups to one another. The K-S compares two or more distributions of data to determine if there is any significant difference between populations. The probability $(\mathrm{P})$ value generated by the K-S test indicates the likelihood of the samples coming from different populations. The higher the $\mathrm{P}$ value the less likely the populations came from different sources. The level of confidence is set at $95 \%$. While the K-S test cannot distinguish if the populations are the same, it can show if the samples are from the same parent location (Gehrels, 2012). The K-S test showed no significant difference between samples indicating that it is statistically likely that the till was generated from the same source area (Table 1). 
TABLE 2: K-S VALUES WITH ERROR

\begin{tabular}{lrrrrrrr} 
& Peoria & Harvard & Tiskilwa & Putnam & Genoa & Shelbyville & Charleston \\
Peoria & & 1.000 & 0.634 & 0.763 & 1.000 & 0.997 & 0.326 \\
Harvard & 1.000 & & 0.955 & 0.966 & 1.000 & 1.000 & 0.352 \\
Tiskilwa & 0.634 & 0.955 & & 1.000 & 0.887 & 0.454 & 0.982 \\
Putnam & 0.763 & 0.966 & 1.000 & & 0.909 & 0.593 & 0.997 \\
Genoa & 1.000 & 1.000 & 0.887 & 0.909 & & 0.999 & 0.374 \\
Shelbyville & 0.997 & 1.000 & 0.454 & 0.593 & 0.999 & & 0.220 \\
Charleston & 0.326 & 0.352 & 0.982 & 0.997 & 0.374 & 0.220 & \\
\hline
\end{tabular}

Cumulative probability (Figure 4.1) and frequency plots (Figure 4.2) were also prepared with the data, both showing the remarkable lack of variability within the data set with both having peak ages at $2703 \mathrm{Ma}$.

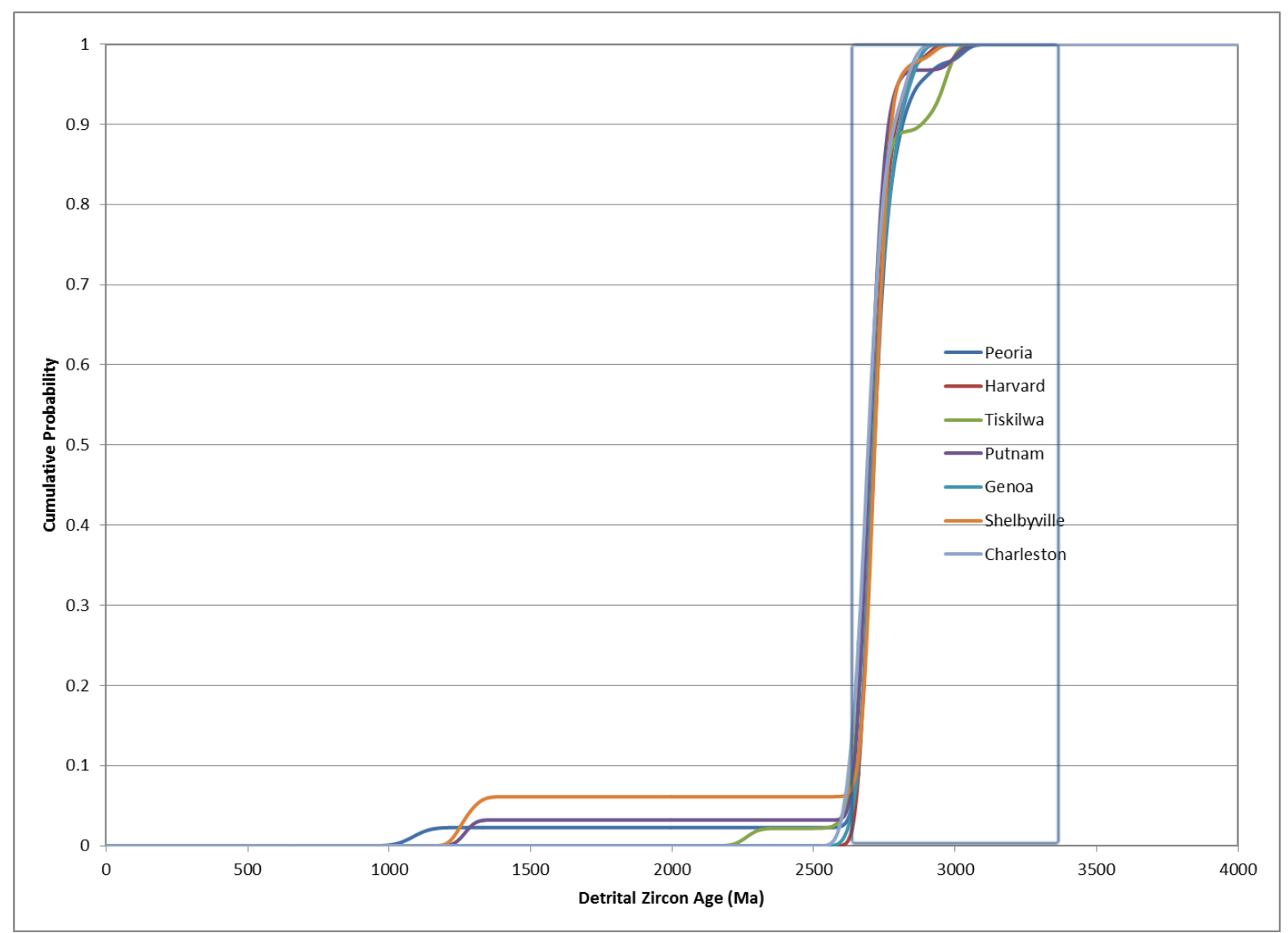

Figure 4.1: Cumulative probability plot for all sample locations with outline showing age range of Hudson Bay Terrane $(3.36-2.69 \mathrm{Ga})$. 


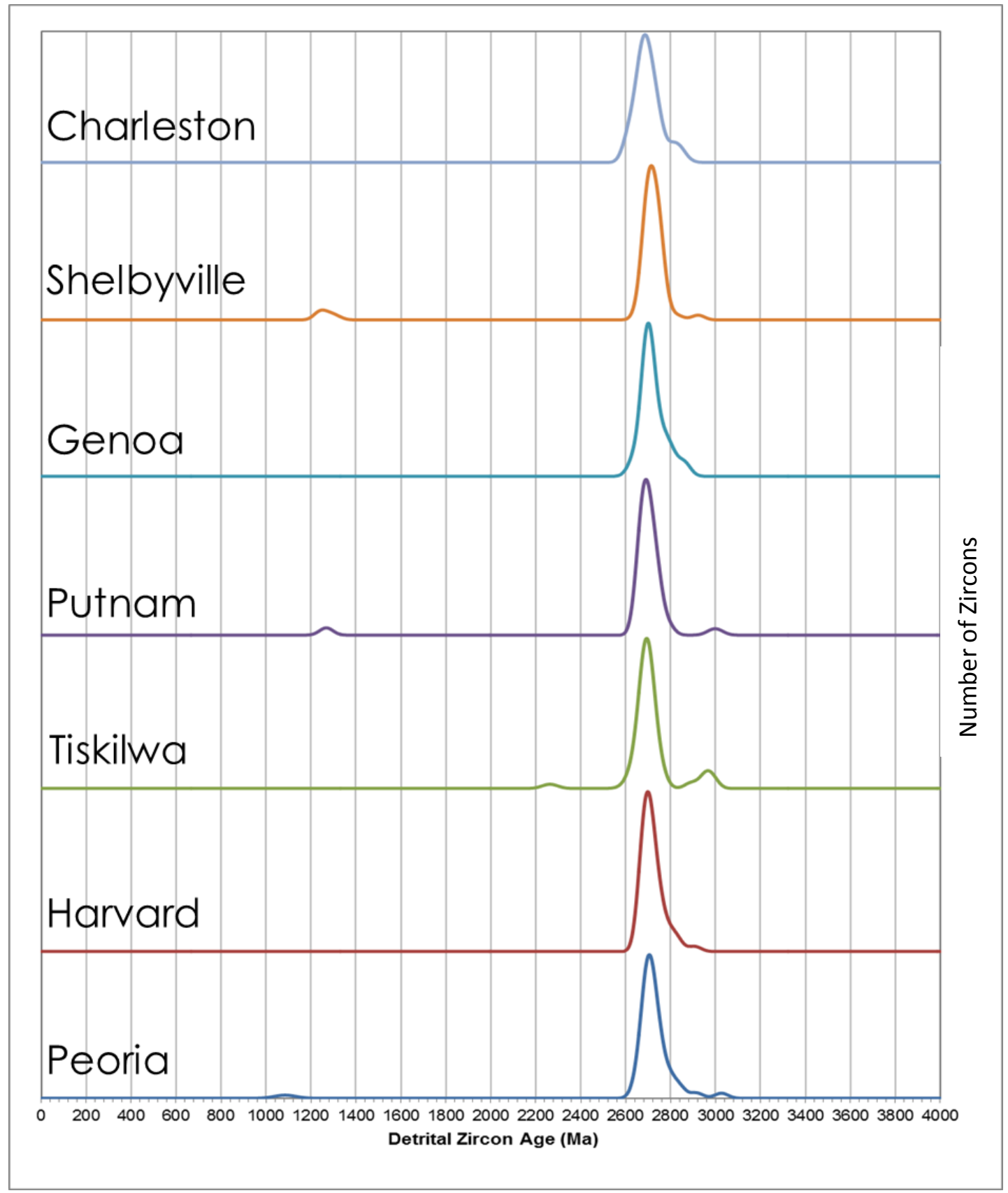

Figure 4.2: Frequency plots of all sample locations. 


\section{DISCUSSION}

The dominance of Archean age grains in all of the samples is noteworthy. With all the samples combined showing a peak age of $2703 \mathrm{Ma}$, the source area for the Tiskilwa till is most certainly derived from the Superior Province and specifically from the Minto Block (Figure 2.1).

Perhaps as important is the similarity of results between this study and a more localized study on the Bloomington and Normal Moraines performed by Rickels (2016). Rickels performed the same geochronology methods and collected clasts locally from the Tiskilwa till and the Batestown member of the Lemont formation (Figure 1.1) (Rickels, 2016). Both locations sampled by Rickels were on a recessional moraine as opposed to the terminal moraines sampled in this study. Rickels' data show peak ages of $2.774 \mathrm{Ga}$ and $2.747 \mathrm{Ga}$ indicating that the provenance of both studies are similar (2016).

This study reaffirms earlier work stating that the ice flow had a Lake Michigan lobe source. If more than one source area was incorporated within the ice, the clast data would have shown more diversity in age. With the data showing such a distinct peak in age, the data supports earlier work that established the ice flow in Illinois as having a Lake Michigan lobe source.

The data and techniques used in this study could potentially be used to support ice flow dynamics. For example, work done by Dyke and Prest (1987) shows the Laurentide ice sheet having several main domes (Figure 4.3). With the lack in variability of clasts, the data collected in this study could support the location of the Hudson Bay dome as the majority of the clasts were likely derived from the Hudson Bay region. 
Further studies would be needed along the ice margins to potentially confirm the existence, or lack thereof, of other domes.

While the data does not lead to revisions of ice flow in Illinois, it does give rise to some questions. One such question is that can the data be used to show system consistencies? The lack of variability in the data collected could show consistencies of the Laurentide sheet. Another question that could potentially be solved using this method is, why is the Tiskilwa Formation till so thick when we do not see modern glaciers depositing such thick tills? Perhaps till geochronology on cobbles could be utilized to determine rates of deposition. Lastly, perhaps the method of only sampling cobbles could grant insights into how ice stream dynamics work in current glaciers. 


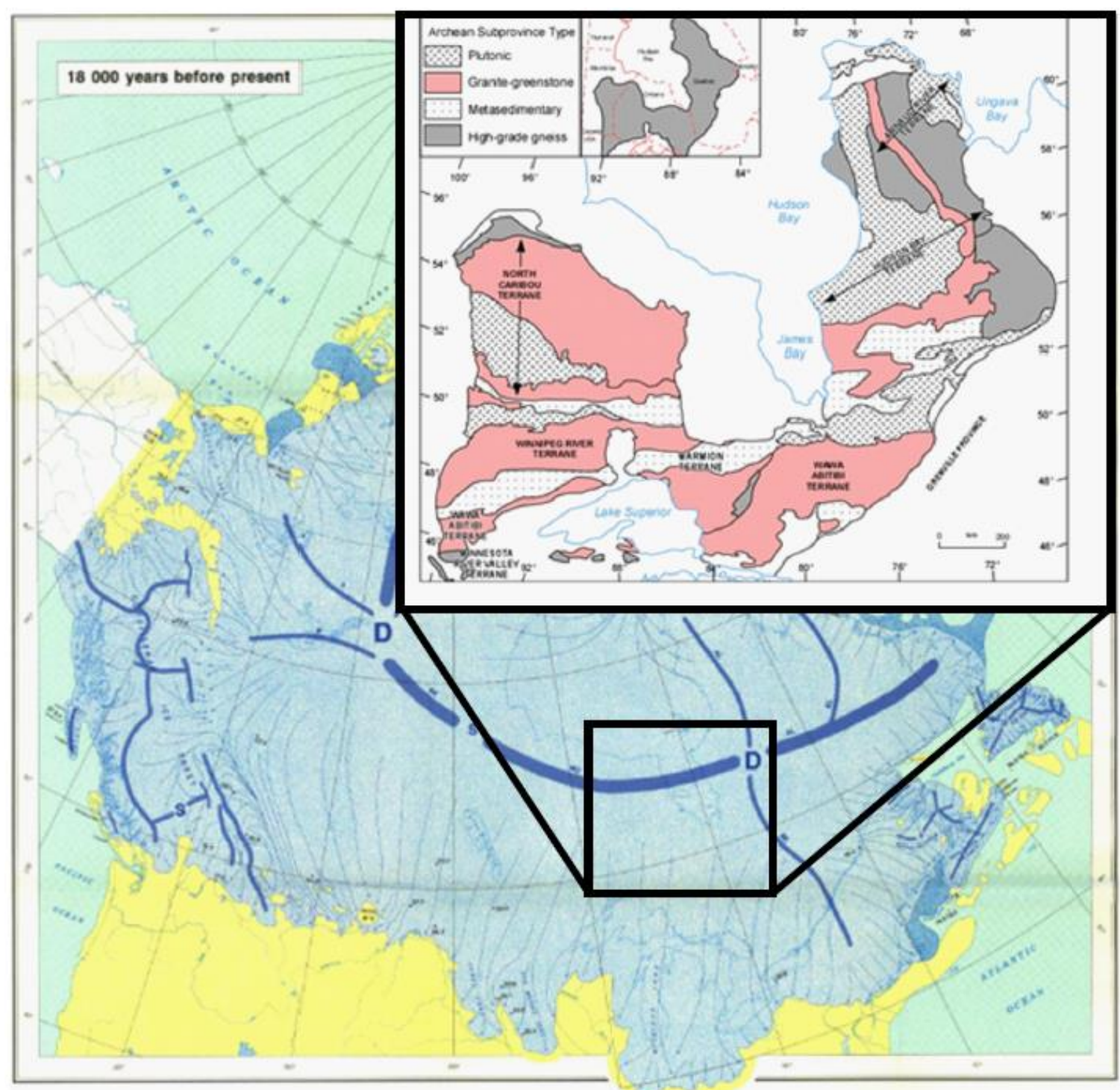

Figure 4.3: Laurentide ice sheet reconstruction showing ice domes from Dyke and Prest, (1987). Inset showing Superior Province from Card and Paulsen (1998). 


\section{CHAPTER V}

\section{SUMMARY, CONCLUSIONS, AND RECOMMENDATIONS}

\section{CONCLUSION}

The initial hypothesis that $\mathrm{U} / \mathrm{Pb}$ dating on glacial erratics in the Tiskilwa Formation till could lead to a revision in glacial lobes of the Wisconsinan episode was not supported. While the data collected during this study did not support the initial hypothesis; however, the data did lead to some important insights on the geochronology of cobbles in glacial till. Geochronology on the Tiskilwa till confirms work performed by Johnson et al. (2006) indicating the source area for the till being derived from one Lake Michigan Lobe. The hypothesis that $\mathrm{U}-\mathrm{Pb}$ ages collected from clasts could lead to a refinement in source area was supported. Zircon analyses further refined the source area to the Hudson Bay Terrain of the Superior Province.

In comparing this studies results, the data collected correlated with data collected by Rickels (2016) on more localized tills. This could prove to be useful as it demonstrated that both regionally and locally, the Tiskilwa till likely has the same provenance. This also demonstrates that the terminal and recessional moraines maintained the same source area. 
While the hypothesis that U-Pb geochronology could lead to a revision of the Wisconsinan age sub-lobes was not supported, the study was successful in using U-Pb geochronology of crystalline cobbles to determine provenance. Further studies are needed to determine if geochronology of cobbles could lead to glacial lobe revision or perhaps further insights on ice flow dynamics. Further studies are also needed to determine it the methodology of selecting only one zircon from each clast could prove to be useful in other till provenance. 


\section{REFERENCES}

Averill S.A. 2001. The application of heavy indicator minerals in mineral exploration. In: McClenaghan M.B., Bobrowsky P.T., Hall G.E.M., Cook S. (eds) Drift Exploration in Glaciated Terrain. Geological Society of London, Special Volume, $185,69-82$.

Black, L., Kamo, S., Allen, C., Davis, D., Aleinikoff, J., Valley, J., Mundil, R., Campbell, I., Korsch, R., Williams, I., and Foudoulis, C., 2004, Improved 206Pb/238U microprobe geochronology by the monitoring of a trace-element-related matrix effect; SHRIMP, ID-TIMS, ELA-ICP-MS and oxygen isotope documentation for a series of zircon standards: Chemical Geology, v. 205, p. 115-140.

Card, K. D., \& Ciesielski, A., 1986, DNAG\# 1. Subdivisions of the Superior Province of the Canadian shield. Geoscience Canada, v. 13, n. 1

Card, K.D. and Paulsen, K.H., 1998, Geology and mineral deposits of the Superior Province of the Canadian Shield, Chapter 2, in Geology of the Precambrian Superior and Grenville Provinces and Precambrian Fossils in North America: Geological Survey of Canada, Geology of Canada Series no. 7, p.13-204.

Card, K.D., 1990, A Review of the Superior Province of the Canadian Shield, a product of Archean accretion. Precambrian Res., 48: 99-156.

Chamberlin, T.C., 1878, On the extent and significance of the Wisconsin kettle moraine: Wisconsin Academy of Science Transactions, v. 4, p. 201-234.

Curry, B.B., D.A. Grimley, and E.D. McKay III, 2011, Quaternary glaciations in Illinois (Chapter 37), in J. Ehlers, P.L. Gibbard and P.D. Hughes, eds., Developments in Quaternary Science, v. 15, Amsterdam, The Netherlands, Elsevier, p. 467-487.

Dreimanis A., Vagners U., 1971. Till: A Symposium Bimodal distribution of rock and mineral fragments in basal tills, ed Goldthwait R. P. (Ohio State University Press), p 237-250. 
Doornbos, C., Heaman, L M., Doupe, J. P., England, J., Simonetti, A., Lajeunesse, P., 2009, The first integrated use of in situ U-Pb geochronology and geochemical analyses to determine long-distance transport of glacial erratics from mainland Canada into the western Arctic Archipelago: Canadian Journal of Earth Science, v. 46 , p. 101-122.

Dyke, A. S., \& Prest, V. K., 1987. Late Wisconsinan and Holocene history of the Laurentide ice sheet. Géographie physique et Quaternaire, v. 41, n. 2, 237-263.

Gehrels, G., 2012. Detrital zircon UePb geochronology: current methods and new opportunities. In: Busby, C., Azor, A. (Eds.), Tectonics of Sedimentary Basins: Recent Advances. Blackwell Publishing, pp. 47e62.

Gehrels, G.E., Valencia, V., Ruiz, J., 2008, Enhanced precision, accuracy, efficiency, and spatial resolution of $\mathrm{U}-\mathrm{Pb}$ ages by laser ablation-multicollector-inductively coupled plasma-mass spectrometry: Geochemistry, Geophysics, Geosystems, v. 9, p. 19-37.

Gwyn. Q.H.J., and A. Dreimanis, 1979, Heavy mineral assemblages in tills and their use in distinguishing glacial lobes in the Great Lakes region: Canadian Journal of Earth Sciences, v. 16, p. 2219-2235.

Hansel, A.K., and Johnson, W.H., 1996, Wedron and Mason Groups: Lithostratigraphic Reclassification of Deposits of the Wisconsin Episode, Lake Michigan Lobe Area: Illinois State Geological Survey, Bulletin 104

Hansel, A.K., and Johnson, W.H., 1992, Fluctuations of the Lake Michigan Lobe during the late Wisconsin Subepisode: Sveriges Geologiska Undersökning, Series Ca 81, p. 133-144.

Johnson, W. H., Hansel, A. K., 1990, Multiple Wisconsinan Glacigenic Sequences At Wedron, Illinois: Journal of Sedimentary Petrology, v. 60, n 1, p. 26-41.

Johnson, W. H., Moore, D.W., and McKay, E.D., 1986, Provenance of late Wisconsinan (Woodfordian) till and origin of the Decatur sublobe, east-central Illinois: Geological Society of America Bulletin, v. 97, p. 109 8-11.

Lasalle, S., Dunning, G., Indares, A., 2014, In situ LA-ICP-MS dating of monazite from aluminous gneisses: insights on the tectono-metamorphic history of a granulitefacies domain in the central Grenville Province: Canadian Journal of Earth Science, v. 51, p. 558-572. 
Leverett, F and Taylor, F.B., 1915, The Pleistocene of Indiana and Michigan and the History of the Great Lakes: U.S. Geological Survey Monograph 53, 529 p.

Licht, K. J., and E. F. Palmer (2013), Erosion and transport by Byrd Glacier, Antarctica during the Last Glacial Maximum, Quat. Sci. Rev., 62, 32-48, doi:10.1016/j.quascirev.2012.11.017.

Lusardi, B. A., Jennings, C. E., and Harris, K. L., 2011, Provenance of Des Moines lobe till records ice stream catchment evolution during Laurentide deglaciation: Boreas, v. 40, p. $585-597$.

Ludwig, R.K., 2008, Isoplot 3.6: Berkeley Geochronology Center, Special Publication 4, $77 \mathrm{p}$.

Malone, D.H., Craddock, J.P., and Mathesin, M.K., 2014, Age and Provenance of Allochthonous Volcanic Rocks at Squaw Peaks, WY: Implications for the Heart Mountain Slide: The Mountain Geologist, v. 51, n. 4, p. 229-344.

Malone, D.H., Craddock, J.P., and Schroeder, K.A., 2014, Detrital Zircon Age and Provenance of Wapiti Formation (Eocene) Tuffaceous Sandstones, South Fork Shoshone River Valley, Wyoming: The Mountain Geologist, v. 51, n. 4, p. 271286.

Milidragovic, D., Francis, D., Weis, D., \& Constantin, M., 2014, Neoarchean (c. 2. 7 Ga) Plutons of the Ungava Craton, Québec, Canada: Parental Magma Compositions and Implications for Fe-rich Mantle Source Regions.Journal of Petrology, v. 55, n. 12 , p. 2481-2512.

McClenaghan, M. B., Thorleifson, L. H., and DiLabio, R. N. W., 2000, Till geochemical and indicator mineral methods in mineral exploration. Ore Geology Reviews, 16(3), 145-166.

Paces, J.B., and Miller, J.D., 1993, Precise U-Pb ages of Duluth Complex and related mafic intrusions, northeastern Minnesota: Geochronological insights to physical, petrogenetic, paleomagnetic, and tectonomagmatic processes associated with the 1.1 Ga midcontinent rift system: Journal of Geophysical Research, v. 98, p. 13997-14013.

Percival, J.A. and Easton, R.M. 2007. Geology of the Canadian Shield in Ontario: an update; Ontario Geological Survey, Open File Report 6196, Geological Survey of Canada, Open File 5511, Ontario Power Generation, Report 06819-REP01200-10158-R00, 65p. 
Percival, J.A., Skulski, T., Sanborn-Barrie, M., Stott, G.M., Leclair, A.D., Corkery, M.T., and Boily, M. 2012, Geology and tectonic evolution of the Superior Province, Canada. Chapter 6 In Tectonic Styles in Canada: The LITHOPROBE Perspective. Edited by J.A. Percival, F.A. Cook, and R.M. Clowes. Geological Association of Canada, Special Paper 49, pp. 321-378.

Prest, V. K., Donaldson, A., Mooers, H. D., 2000, The Omar Story: The Role of Omars in Assessing Glacial History of West-Central North America: Geographie physique et Quaternaire, v. 54, n.3, p. 257-270.

Plouffe, A, Bednarski, J.M., Huscroft, C.A., Anderson, R.G., and McCuaig, S.J., 2011, Late Wisconsinan glacial history in the Bonaparte Lake map area, south-central British Columbia: implications for glacial transport and mineral exploration: Canadian Journal of Earth Sciences, v. 48, p. 1091-1111.

Raharimahefa, T., Lafrance, B., Tinkham, D. K., 2014, New structural, metamorphic, and $\mathrm{U}-\mathrm{Pb}$ geochronological constraints on the Blezardian Orogeny and Yavapai Orogeny in the Southern Province, Sudbury, Canada: Canadian Journal of Earth Science, v. 51, p. 750-774.

Rickels, E.S., 2016, Surficial Geology and Provenance of Glacial Deposits of the Saybrook 7.5 Minute Quadrangle, McLean County, Illinois. [M.S. Thesis] Illinois State University, 53p

Roy, M., Clark, P.U., Duncan, R.A. and Hemming, S.R. 2007, Insights into the late Cenozoic configuration of the Laurentide Ice Sheet from 40Ar/39Ar dating of glacially transported minerals in midcontinent tills, Geochemistry Geophysics Geosystems, 8: 1-12.

Schmitz, M.D., Bowring, S.A., and Ireland, T., 2003, Evaluation of Duluth Complex anorthositic series (AS3) zircon as a U-Pb geochronological standard: New highprecision isotope dilution thermal ionization mass spectrometry results:

Geochimica et Cosmochimica Acta, v. 67, n. 19, p. 3665-3672.

Stacey, J.S., and Kramers, J.D., 1975, Approximation of terrestrial lead isotope evolution by a two-stage model: Earth and Planetary Science Letters, v. 26, p. 207-221.

Wickham, S. S., Johnson, W. H., Glass, H. D., 1988. Regional Geology of T he Tiskilwa Till Member, Wedron Formation, Northeastern Illinois: Illinois State Geological Survey. Circular, 543.

Welke, B., Licht, K., Hennessy, A., Hemming, S., Pierce Davis, E., \& Kassab, C., 2016. Applications of detrital geochronology and thermochronology from glacial deposits to the Paleozoic and Mesozoic thermal history of the Ross Embayment, Antarctica. Geochemistry, Geophysics, Geosystems, v. 17, n. 7, p. 2762-2780. 
Willman, H.B., and J.C. Frye, 1970, Pleistocene stratigraphy of Illinois: Illinois State Geological Survey, Bulletin 94, 204 p.

Zimmermann, U., Andersen, T., Madland, M. V., \& Larsen, I. S., 2015, The role of U-Pb ages of detrital zircons in sedimentology — An alarming case study for the impact of sampling for provenance interpretation. Sedimentary Geology, v. 320, p. 3850 . 
APPENDIX A

\section{FREQUENCY PLOTS FOR ALL SAMPLING LOCATIONS}

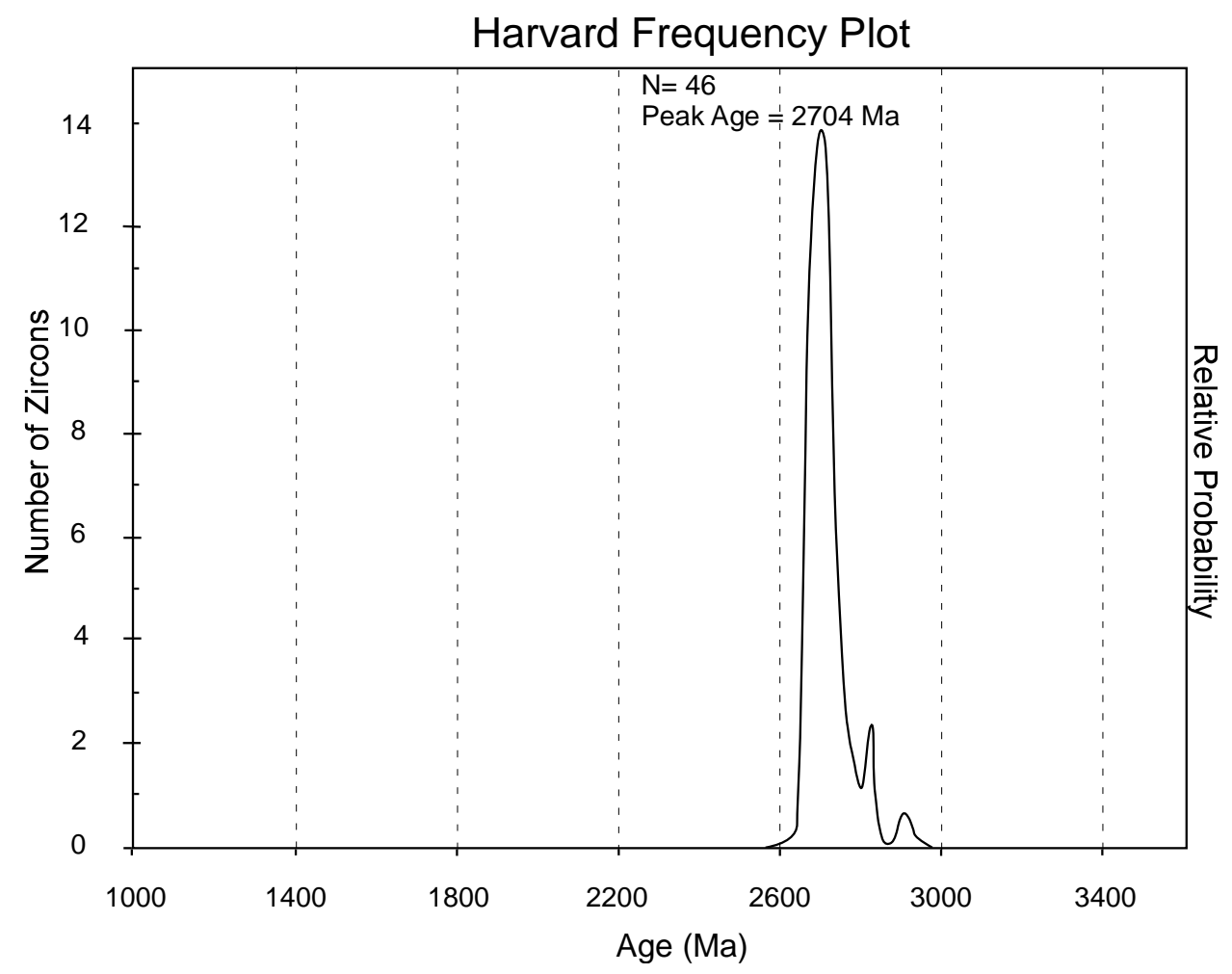



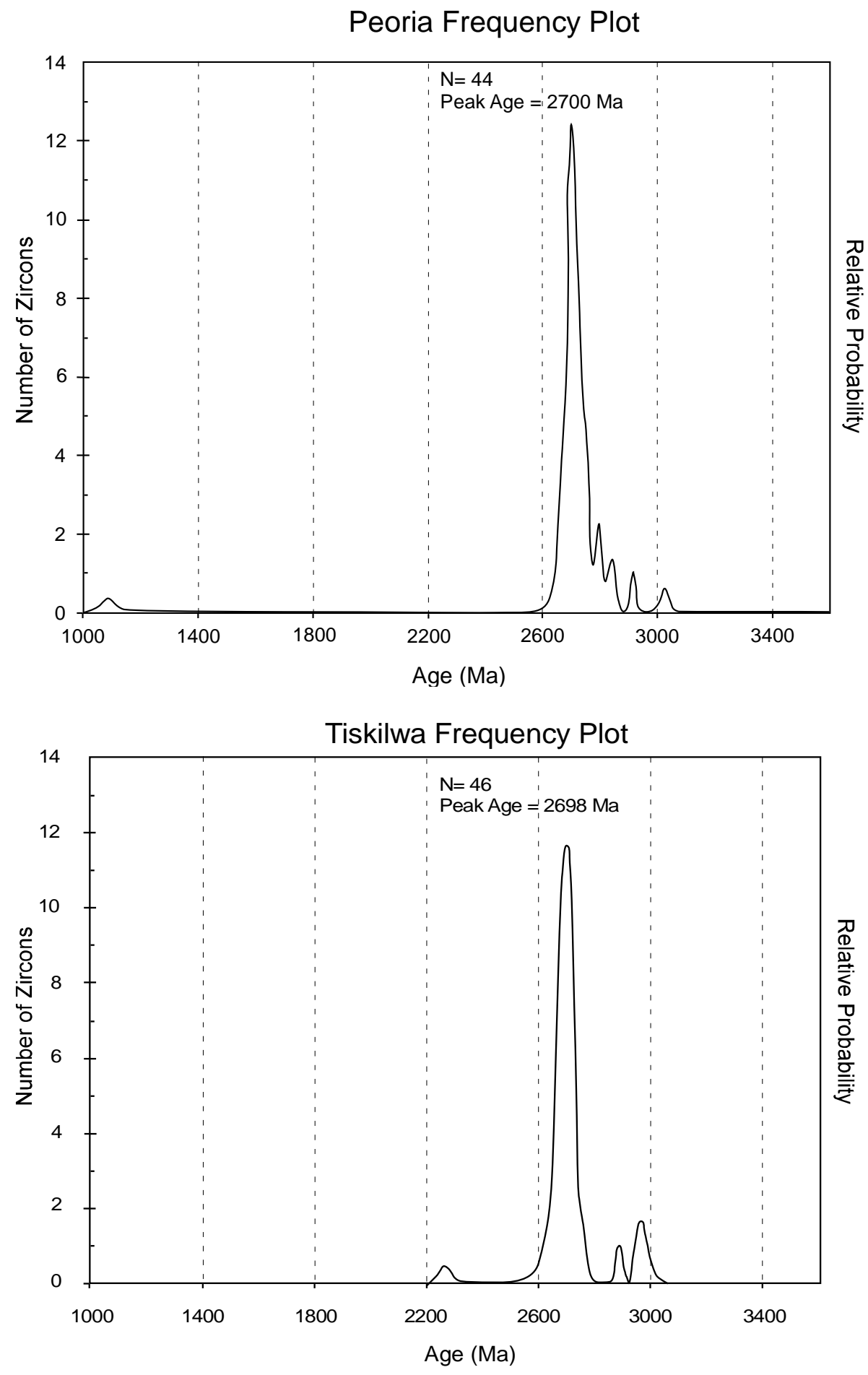

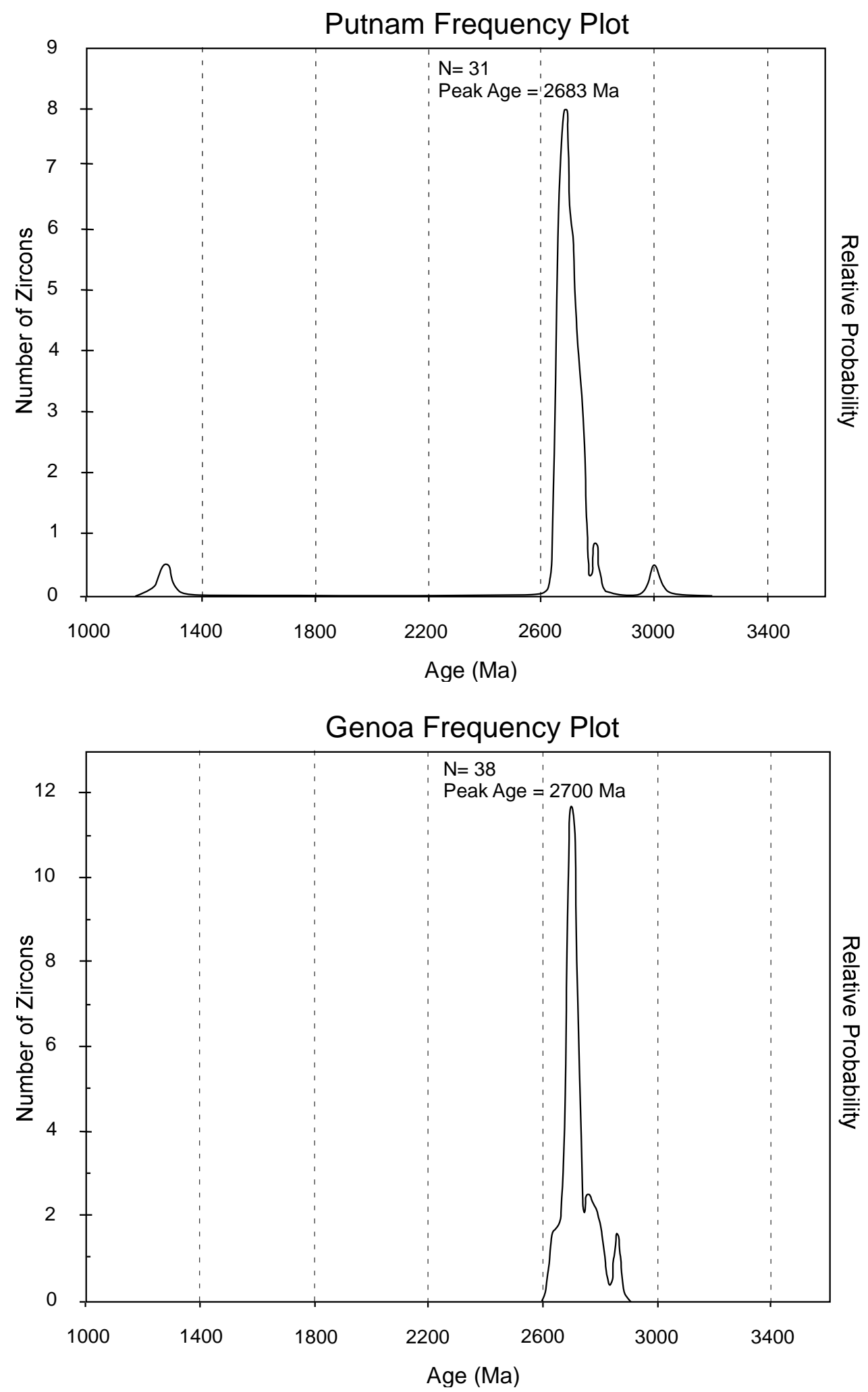

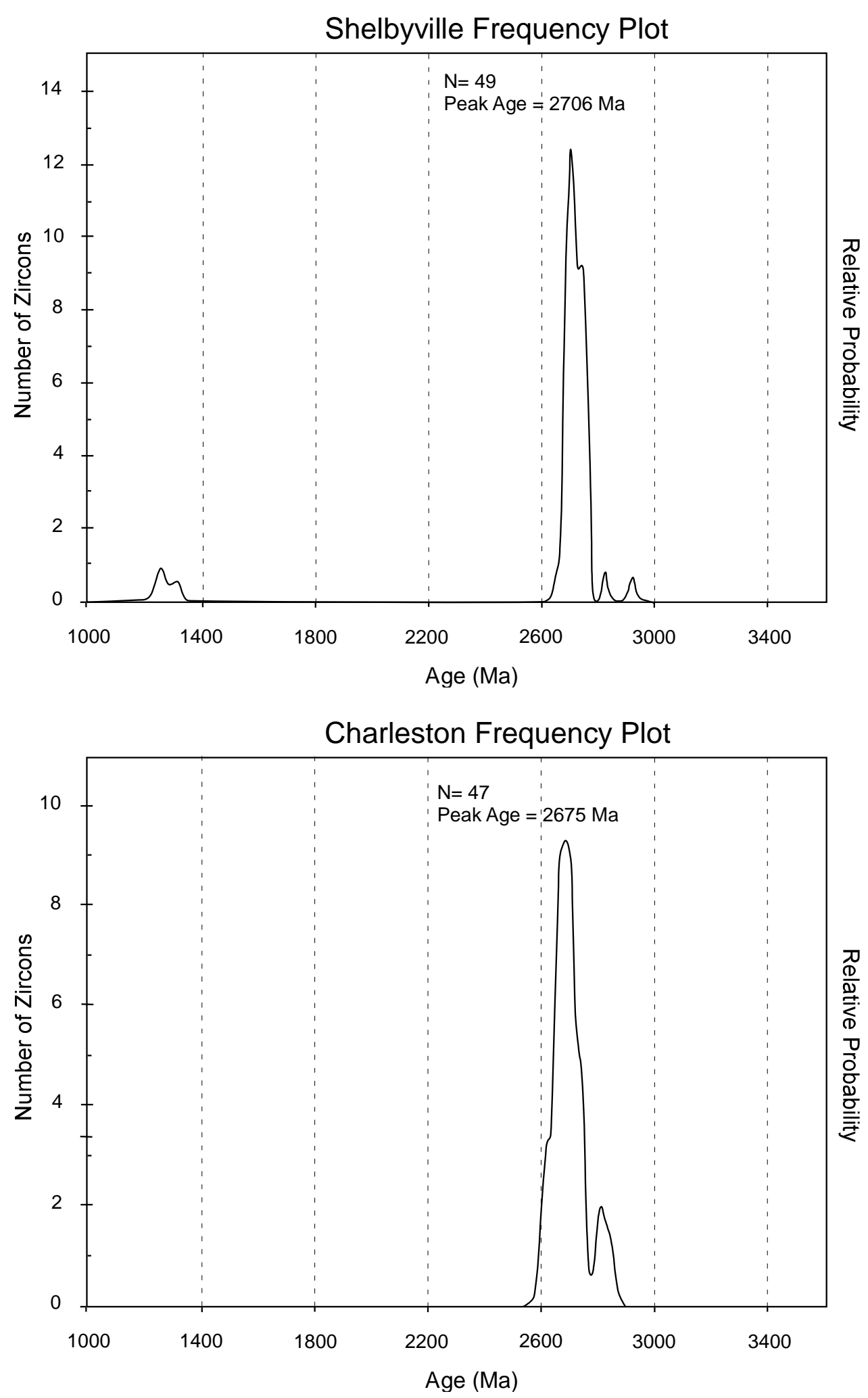


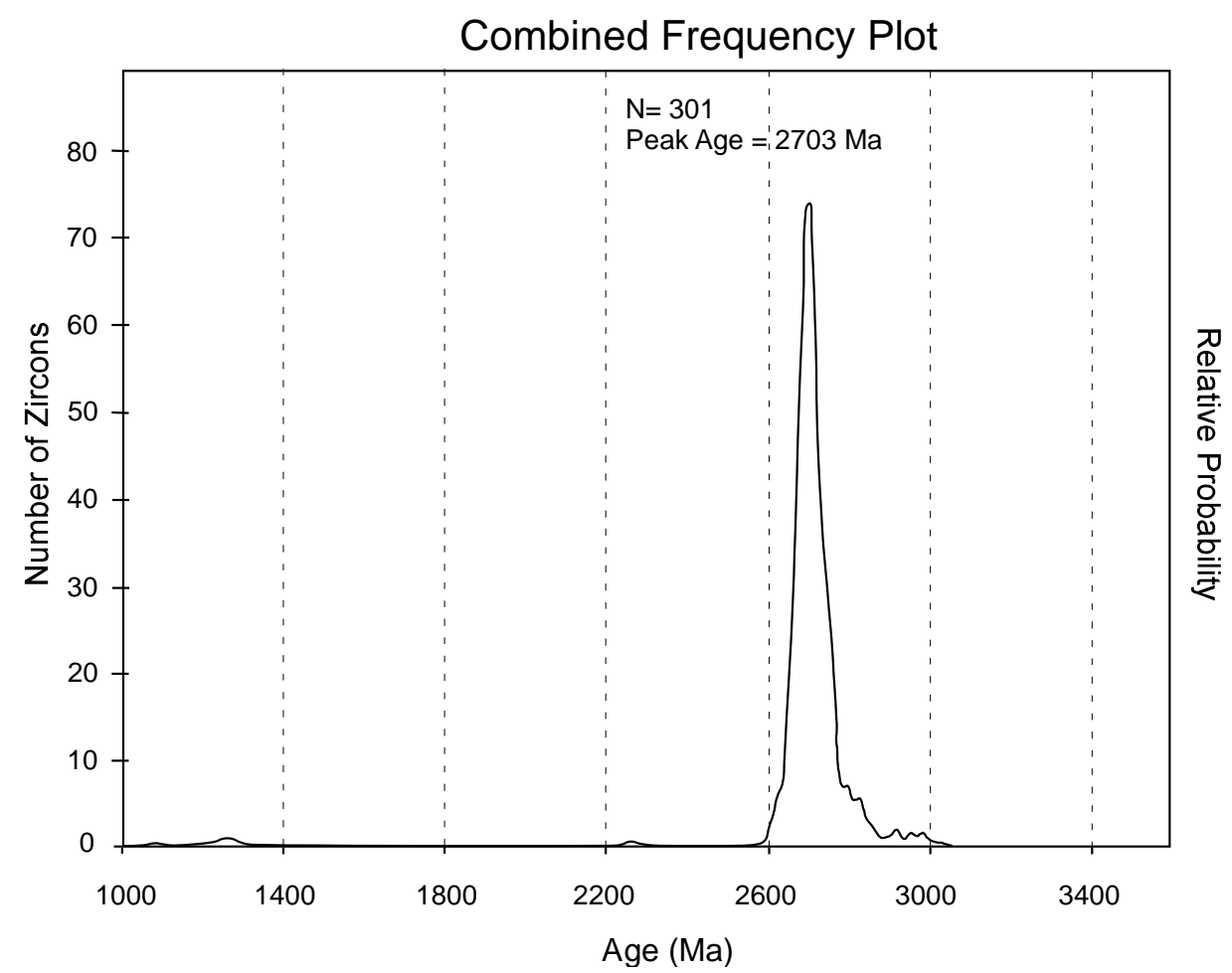


APPENDIX B

\section{CONCORDIA PLOTS FOR ALL SAMPLING LOCATIONS}

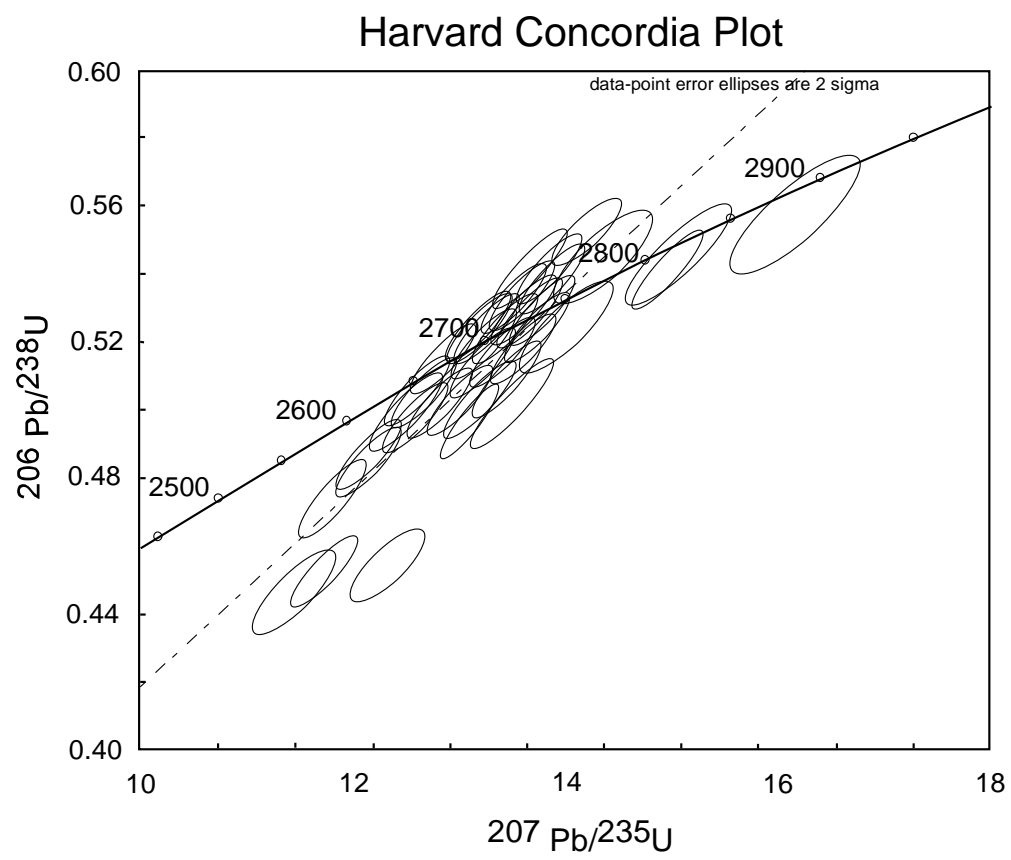



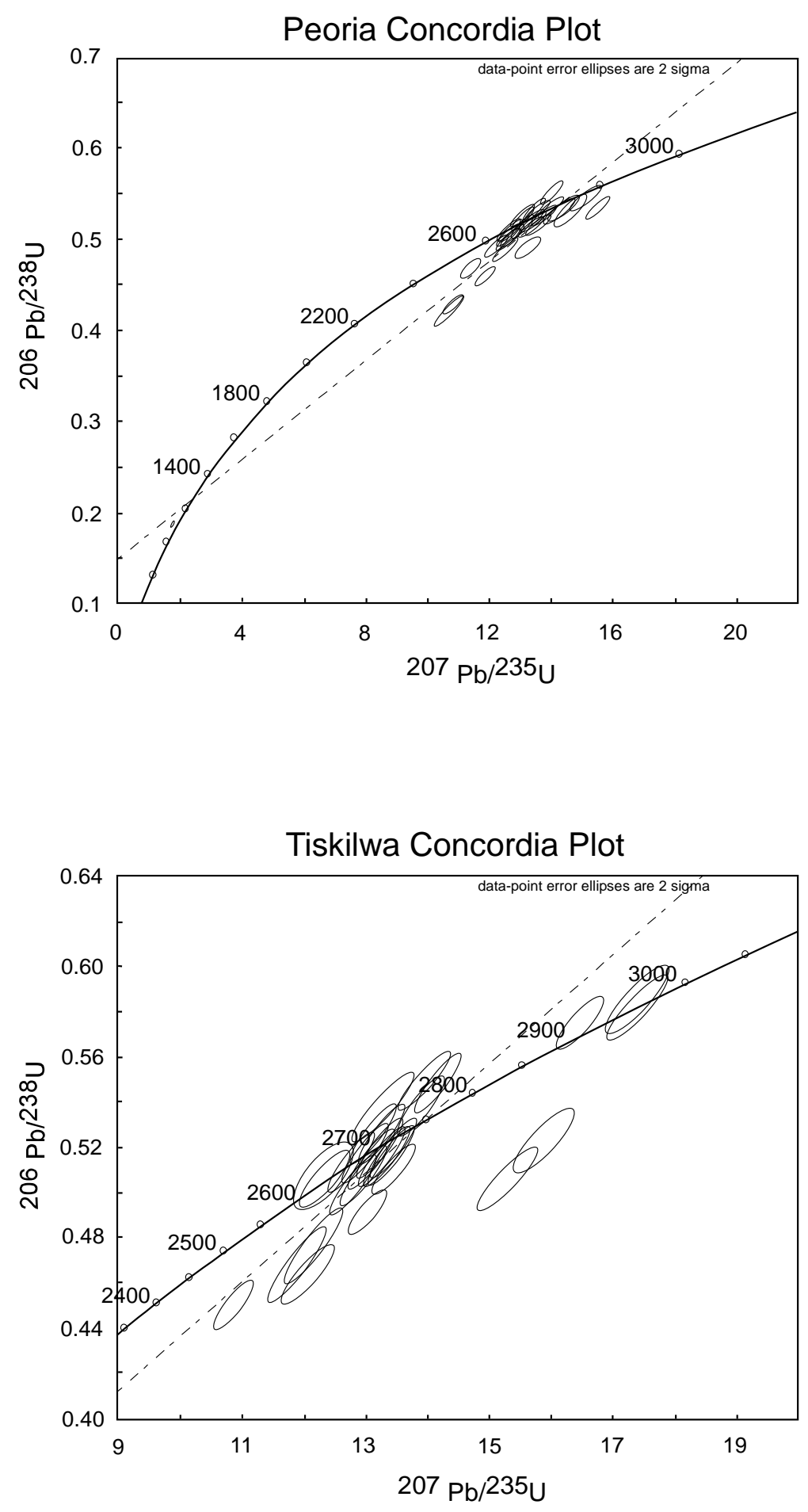

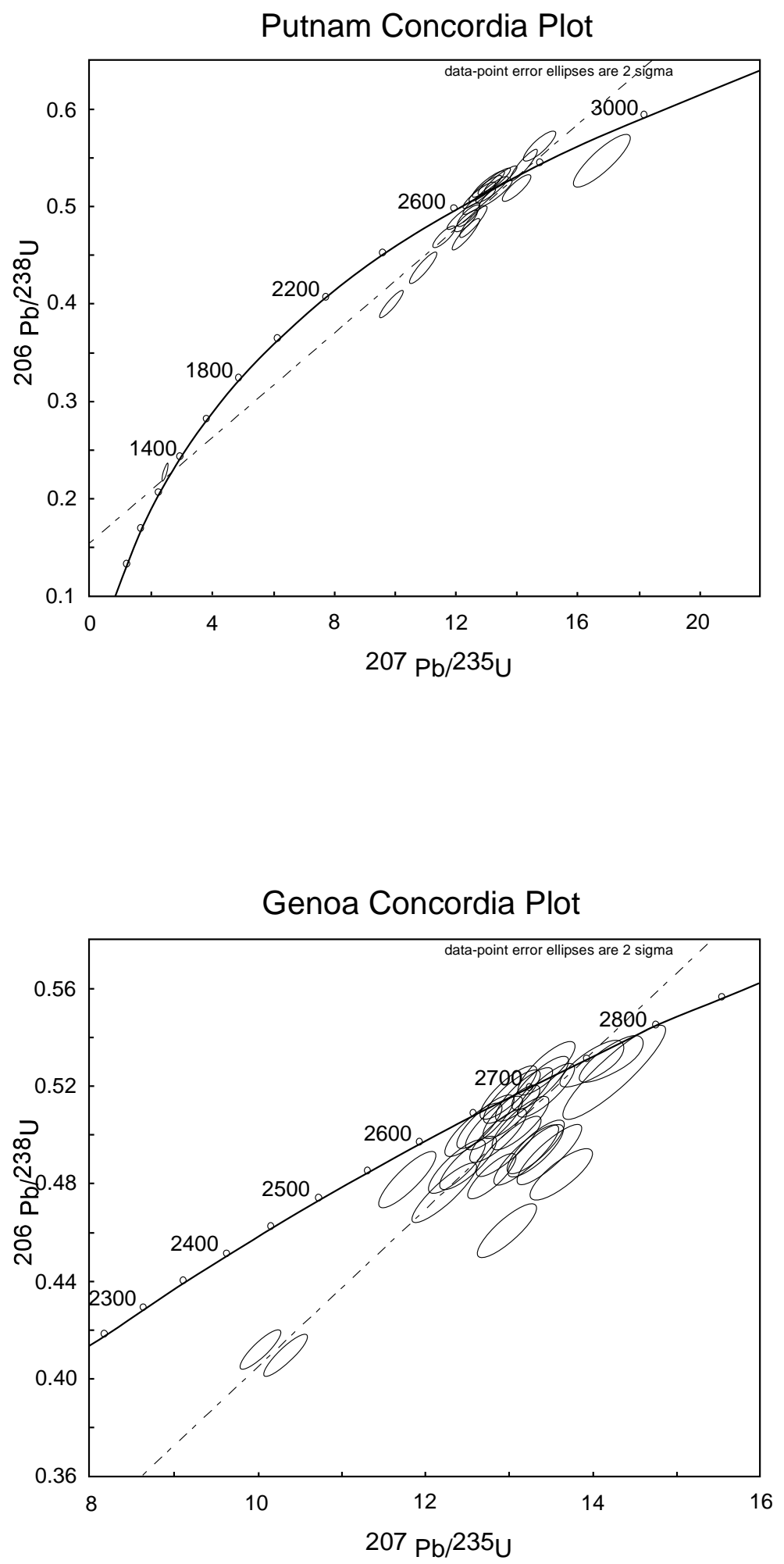

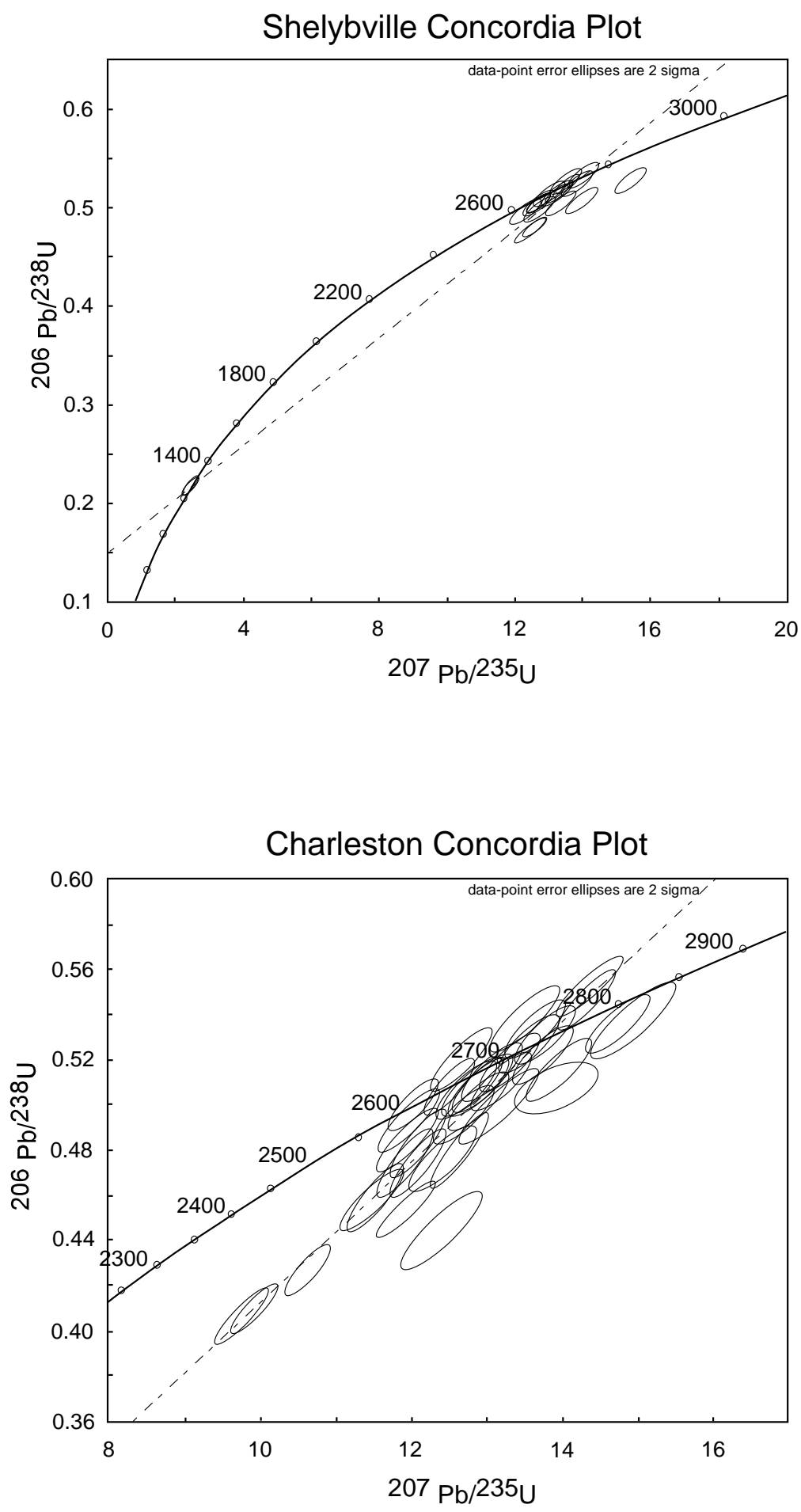


\section{APPENDIX C \\ COMPLETE DATA FOR ALL SAMPLING LOCATIONS}

1. 1. Analyses with $>10 \%$ uncertainty (1-sigma) in $206 \mathrm{~Pb} / 238 \mathrm{U}$ age are not included.

2. Analyses with $>10 \%$ uncertainty (1-sigma) in $206 \mathrm{~Pb} / 207 \mathrm{~Pb}$ age are not included, unless $206 \mathrm{~Pb} / 238 \mathrm{U}$ age is $<500 \mathrm{Ma}$.

3. Best age is determined from $206 \mathrm{~Pb} / 238 \mathrm{U}$ age for analyses with $206 \mathrm{~Pb} / 238 \mathrm{U}$ age $<1000 \mathrm{Ma}$ and from $206 \mathrm{~Pb} / 207 \mathrm{~Pb}$ age for analyses with $206 \mathrm{~Pb} / 238 \mathrm{Uage}>1000$ Ma.

4. Concordance is based on $206 \mathrm{~Pb} / 238 \mathrm{U}$ age $/ 206 \mathrm{~Pb} / 207 \mathrm{~Pb}$ age. Value is not reported for $206 \mathrm{~Pb} / 238 \mathrm{U}$ ages $<500 \mathrm{Ma}$ because of large uncertainty in $206 \mathrm{~Pb} / 207 \mathrm{~Pb}$ age.

5. Analyses with $206 \mathrm{~Pb} / 238 \mathrm{U}$ age $>500 \mathrm{Ma}$ and with $>20 \%$ discordance $(<80 \%$ concordance) are not included.

6. Analyses with $206 \mathrm{~Pb} / 238 \mathrm{U}$ age $>500 \mathrm{Ma}$ and with $>5 \%$ reverse discordance ( $<105 \%$ concordance) are not included.

7. All uncertainties are reported at the 1-sigma level, and include only measurement errors.

8. Systematic errors are as follows (at 2-sigma level): [sample 1: $2.5 \%$ (206Pb/238U) $\& 1.4 \%(206 \mathrm{~Pb} / 207 \mathrm{~Pb})]$ These values are reported on cells $\mathrm{U} 1$ and $\mathrm{W} 1$ of NUagecalc. 


\section{Peoria Analysis (sorted by best age)}

\begin{tabular}{|c|c|c|c|c|c|c|c|c|c|c|c|c|c|c|c|c|c|c|c|}
\hline \multirow[b]{2}{*}{ Analysis } & \multirow[b]{2}{*}{ r } & \multirow[b]{2}{*}{$206 \mathrm{~Pb}$} & \multirow[b]{2}{*}{$\mathrm{U} / \mathrm{Th}$} & \multirow[b]{2}{*}{$206 \mathrm{~Pb}^{*}$} & \multicolumn{3}{|c|}{ Isotope ratios } & \multirow[b]{2}{*}{$206 \mathrm{~Pb}^{*}$} & \multirow[b]{2}{*}{ \pm} & \multirow[b]{2}{*}{ error } & \multirow[b]{2}{*}{$206 \mathrm{~Pb}^{*}$} & \multirow[b]{2}{*}{ \pm} & \multicolumn{3}{|c|}{ Apparent ages (Ma) } & \multirow[b]{2}{*}{ \pm} & \multirow[b]{2}{*}{ Best age } & \multirow[b]{2}{*}{ \pm} & \\
\hline & & & & & \pm & $207 \mathrm{~Pb}^{*}$ & \pm & & & & & & $207 \mathrm{~Pb}^{*}$ & \pm & $06 \mathrm{~Pb}^{*}$ & & & & Conc \\
\hline & (ppm) & $204 \mathrm{~Pb}$ & & 207Pb* & $(\%)$ & $235 U^{*}$ & $(\%)$ & $238 \mathrm{U}$ & $(\%)$ & corr. & $238 U^{*}$ & (Ma) & $235 \mathrm{U}$ & (Ma) & 207Pb* & (Ma) & (Ma) & (Ma) & \\
\hline & & & & & & & & & & & & & & & & & & & \\
\hline 38 & 20 & 30010 & 0.6 & & 2.5 & & 3.0 & & 1.7 & 0.57 & & 17.1 &. .1 & $<0.1$ & 085.9 & & & 49.6 & 100.5 \\
\hline Spot 40 & 660 & 255966 & 1.5 & 5.5993 & 1.6 & 11.5068 & 2.5 & 0.4673 & 1.9 & 0.77 & 2471.7 & 39.1 & 2565.1 & 23.3 & 2639.8 & 26.6 & 639.8 & 26.6 & 93.6 \\
\hline Spot 25 & 205 & 61160 & 4.7 & 5.5315 & 1.1 & 2.6438 & 2.1 & .5072 & 1.8 & 0.85 & 2644.8 & 39.3 & 2653.5 & 20.0 & 2660.1 & 18.4 & 2660.1 & 18.4 & 99.4 \\
\hline Spot 26 & 542 & 80655 & 2.0 & 5.5158 & 1.1 & 2.2759 & 2.4 & 0.4911 & 2.1 & 0.88 & 2575.4 & \begin{tabular}{|l|}
44.8 \\
\end{tabular} & 2625.7 & 22.5 & 2664.8 & 18.9 & 2664.8 & 18.9 & 96.6 \\
\hline Spot 12 & 194 & 2556728 & 5.3 & 5.5058 & 1.2 & 3.1350 & 2.5 & 0.5245 & 2.2 & 0.88 & 2718.3 & 48.8 & 2689.4 & 23.5 & 2667.8 & 19.3 & 2667.8 & 19.3 & 101.9 \\
\hline Spot 1 & 148 & 77866 & 7.0 & 5.4643 & 1.4 & 3.1845 & 3.0 & .5225 & 2.6 & 0.87 & 2709.8 & 57.8 & 2692.9 & 28.2 & 2680.3 & 23.9 & 2680.3 & 23.9 & 101.1 \\
\hline Spot 7 & 78 & 143516 & 8.2 & 5.4581 & 1.3 & 2.8282 & 2.2 & .5078 & 1.7 & 0.81 & 2647.3 & 37.9 & 2667.1 & 20.4 & 2682.2 & 21.2 & 2682.2 & 21.2 & \\
\hline Spot 30 & 191 & 206574 & 3.6 & 5.4521 & 1.6 & 2.7439 & 2.7 & .5039 & 2.2 & 0.81 & 2630.6 & \begin{tabular}{|l|}
47.8 \\
\end{tabular} & 2660.9 & 25.7 & 2684.0 & 26.3 & 2684.0 & 26.3 & 8.0 \\
\hline Spot 11 & 153 & 185869 & 13.5 & 5.4253 & 0.9 & 2.8904 & 2.3 & .5072 & 2.1 & 0.91 & 2644.7 & \begin{tabular}{|l|}
45.2 \\
\end{tabular} & 2671.7 & 21.6 & 2692.1 & 15.7 & 2692.1 & 15.7 & 98.2 \\
\hline Spot 22 & 194 & 139978 & 5.3 & 5.4253 & 1.3 & 12.7050 & 2.6 & .4999 & 2.2 & 0.86 & 2613.4 & 47.0 & 2658.0 & 24.1 & 2692.1 & 21.8 & 2692.1 & 21.8 & 97.1 \\
\hline Spot 49 & 119 & 81073 & 1.9 & 5.4227 & 1.7 & 70 & 3.0 & 5151 & 2.5 & 0.83 & 2678.3 & 54.3 & 686.7 & 28.2 & 2692.9 & 27.5 & 2692.9 & 27.5 & 99.5 \\
\hline Spot 31 & 729 & 264963 & \begin{tabular}{|l|}
43.7 \\
\end{tabular} & 5.4192 & \begin{tabular}{|l}
1.0 \\
\end{tabular} & 2.8427 & 2.5 & 5048 & 2.3 & 0.92 & 2634.2 & \begin{tabular}{|l|}
50.2 \\
\end{tabular} & 2668.2 & 23.8 & 2694.0 & 16.6 & 2694.0 & 16.6 & 97.8 \\
\hline Spot 29 & 49 & 71239 & 1.7 & 5.4188 & 1.0 & 2.9542 & 2.2 & .5091 & 2.0 & 0.89 & 2652.8 & \begin{tabular}{|l|}
42.4 \\
\end{tabular} & 2676.3 & 20.6 & 2694.1 & 16.2 & 2694.1 & 16.2 & 98.5 \\
\hline Spot 28 & 270 & 3824 & 3.8 & 5.4142 & 1.3 & 31 & 2.5 & 5153 & 2.2 & 0.87 & 2679.2 & \begin{tabular}{|l|}
48.2 \\
\end{tabular} & 2688.5 & 24.0 & 2695.5 & 21.0 & 2695.5 & 21.0 & 9.4 \\
\hline Spot 17 & 64 & 199053 & 1.7 & 5.4090 & 1.5 & 60 & 2.5 & .5102 & 2.0 & 0.80 & 2657.6 & \begin{tabular}{|l|}
43.5 \\
\end{tabular} & 2680.1 & 23.4 & 2697.1 & 24.5 & 2697.1 & 24.5 & 98.5 \\
\hline Spot 3 & 96 & 48638 & 1.5 & 5.4038 & 1.4 & 3.2625 & 2.7 & .5198 & 2.3 & 0.86 & 2698.3 & \begin{tabular}{|l|}
51.4 \\
\end{tabular} & 2698.5 & 25.5 & 2698.7 & 22.6 & 2698.7 & 22.6 & 100.0 \\
\hline Spot 18 & 760 & 220984 & 0.6 & 5.3965 & 1.3 & 80 & 2.5 & 4277 & 2.1 & 0.85 & 2295.4 & \begin{tabular}{|l|}
41.0 \\
\end{tabular} & 2517.0 & 23.2 & 2700.9 & 21.7 & 2700.9 & 21.7 & 0 \\
\hline Spot 47 & 38 & 78288 & 0.6 & 5.3949 & 1.2 & 01 & 2.4 & 5333 & 2.0 & 0.85 & 2755.4 & \begin{tabular}{|l|}
45.1 \\
\end{tabular} & 2724.4 & 22.3 & 2701.4 & 20.3 & 2701.4 & 20.3 & 02.0 \\
\hline Spot 50 & 139 & 90603 & 3.4 & 5.3860 & 1.0 & 73 & 2.2 & .5507 & 2.0 & 0.89 & 2828.0 & 46.0 & 2756.3 & 21.3 & 2704.1 & 16.7 & 2704.1 & 16.7 & 104.6 \\
\hline Spot 32 & 4 & 7959 & 1.7 & .3815 & 1.2 & 34 & 2.7 & 5064 & \begin{tabular}{|l|}
2.4 \\
\end{tabular} & 0.90 & 2641.1 & \begin{tabular}{|l|}
52.2 \\
\end{tabular} & 2677.7 & 25.3 & 2705.5 & 19 & 2705.5 & 19.6 & 97.6 \\
\hline Spot 15 & 167 & 5558 & 1.4 & 5.3805 & 1.1 & 01 & 2.3 & 5034 & 2.1 & 0.89 & 2628.4 & \begin{tabular}{|l|}
44.3 \\
\end{tabular} & 2672.4 & 21.8 & 2705.8 & 17.7 & 2705.8 & 17.7 & 97.1 \\
\hline Spot 39 & 334 & 9224 & 35.1 & .3652 & 1.4 & 62 & 3.5 & 4197 & 3.2 & 0.92 & 2259.2 & \begin{tabular}{|l|}
60.7 \\
\end{tabular} & 2504.9 & 32.4 & 2710.5 & 23.1 & 2710.5 & 23.1 & 83.3 \\
\hline Spot 37 & & 75506 & 1.4 & 5.3426 & 1.2 & 71 & 2.4 & .4955 & 2.1 & 0.86 & 2594.3 & \begin{tabular}{|l}
44.2 \\
\end{tabular} & 2664.1 & 22.6 & 2717.5 & 20 & 2717.5 & 0 & 00.0 \\
\hline Spot 44 & 486 & 5745 & 1.3 & .3416 & 1.0 & 80 & 2.3 & 5043 & 2.1 & 0.90 & 2632.4 & 45.0 & 31.0 & 21.9 & 2717.8 & 17.1 & 2717.8 & 17.1 & 96.9 \\
\hline Spot 2 & 178 & 9133 & 1.6 & 3357 & 1.4 & 52 & 2.7 & .5099 & 2.3 & 0.86 & 2656.0 & \begin{tabular}{|l|}
49.7 \\
\end{tabular} & 2692.3 & 25.1 & 2719.6 & 22.5 & 2719.6 & 22.5 & 97.7 \\
\hline Spot 19 & 602 & 426 & 6.8 & 331 & 1.4 & & 2.6 & 5197 & 2.2 & 0.85 & 2698.1 & \begin{tabular}{|l|}
49.3 \\
\end{tabular} & 0.9 & 24.9 & 2720.4 & 23.0 & 2720.4 & 23.0 & \\
\hline Spot 4 & 116 & 617 & 1.6 & 00 & 1.5 & & 2.4 & 301 & 1.9 & 0.77 & 2741.8 & 41.5 & 0.1 & 22.9 & 2721.4 & 25.4 & 2721.4 & 25.4 & 100.7 \\
\hline Spot 36 & 549 & 8081 & 2.4 & 3267 & \begin{tabular}{|l|}
1.4 \\
\end{tabular} & 12.6573 & 2.8 & .4890 & 2.5 & 0.87 & 2566.3 & \begin{tabular}{|l|}
52.2 \\
\end{tabular} & 2654.5 & 26.5 & 2722.4 & 22.6 & 2722.4 & 22.6 & 94.3 \\
\hline Spot 13 & 565 & 32555 & 11.1 & 3108 & 1.3 & & 2.7 & .5162 & 2.4 & 0.88 & 2682.9 & 51.6 & 2708.3 & 25.4 & 2727.3 & 21.3 & 2727.3 & .3 & 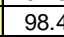 \\
\hline Spot 24 & 210 & 2022 & 2.4 & 2949 & 1.2 & & 2.3 & .5148 & 2.0 & 0.85 & 2677.0 & \begin{tabular}{|l}
43.0 \\
\end{tabular} & 2708.6 & 21.7 & 2732.2 & 19.8 & 2732.2 & 19.8 & 98.0 \\
\hline Spot 46 & 502 & 6185 & 1.9 & 5.2874 & 1.2 & 754 & 2.4 & 0.4592 & 2.0 & 0.86 & 2436.1 & \begin{tabular}{|l|}
41.1 \\
\end{tabular} & 2602.5 & 22.1 & 2734.6 & 19.8 & 2734.6 & 19.8 & 89.1 \\
\hline Spot 6 & 9 & 5399 & 4.4 & 5.2715 & 1.4 & 4818 & 2.9 & .5154 & 2.5 & 0.87 & 2679.8 & 55.5 & 2714.0 & 27.5 & 2739.5 & 23.4 & 2739.5 & 23.4 & 97.8 \\
\hline Spot 5 & & 3024 & 0.1 & .2614 & 1.1 & & 2.5 & .5303 & 2.3 & 0.90 & 2742.6 & 51.0 & 2742.7 & 24.2 & 2742.7 & 18.6 & 2742.7 & 18.6 & 100.0 \\
\hline Spot 34 & 456 & 7672 & 2.1 & 5.2231 & 1.1 & 345 & 2.3 & 0.5252 & 2.0 & 0.89 & 2721.2 & \begin{tabular}{|l|}
44.4 \\
\end{tabular} & 2740.5 & 21.4 & 2754.7 & 17.3 & 2754.7 & \begin{tabular}{|l|}
17.3 \\
\end{tabular} & 98.8 \\
\hline Spot 10 & 334 & 184220 & 2.3 & 5.2228 & 1.1 & 54 & 2.1 & .5343 & 1.8 & 0.85 & 2759.6 & \begin{tabular}{|l|}
40.7 \\
\end{tabular} & 2756.8 & 20.2 & 2754.8 & 18.5 & 754.8 & 18.5 & 100.2 \\
\hline Spot 8 & 0 & 3624 & 2.3 & 5.2143 & 1.4 & 10 & 2.5 & 0.5238 & 2.0 & 0.83 & 2715.3 & \begin{tabular}{|l|}
45.2 \\
\end{tabular} & 2739.6 & 23.3 & 2757.5 & 22.8 & 2757.5 & 22.8 & 98.5 \\
\hline Spot 20 & 315 & 77690 & 2.4 & 5.2040 & 1.1 & 13.5925 & 2.0 & 0.5130 & \begin{tabular}{|l|}
1.7 \\
\end{tabular} & 0.85 & 2669.5 & \begin{tabular}{|l|}
37.8 \\
\end{tabular} & 2721.7 & 19.3 & 2760.7 & 17.7 & 2760.7 & 17.7 & 96.7 \\
\hline Spot 9 & 188 & 187961 & 2.2 & .1096 & 1.3 & 4.3127 & 2.7 & .5304 & 2.3 & 0.87 & 2743.2 & 51.6 & 2770.7 & 25.2 & 2790.7 & 21.5 & 2790.7 & 21.5 & 98.3 \\
\hline Spot 21 & 7 & 56606 & 1.7 & 5.0999 & 1.3 & 14.4 & 2.6 & 0.5333 & 2.3 & 0.87 & 2755.2 & 51.1 & 2777.6 & 25.0 & 2793.8 & 21.5 & 2793.8 & 21.5 & 98.6 \\
\hline Spot 35 & 18 & 28670 & 0.5 & 5.0713 & 1.7 & 13.3342 & 2.7 & 0.4904 & 2.1 & 0.77 & 2572.6 & 44.8 & 2703.6 & 25.9 & 2803.1 & 28.5 & 2803.1 & 28.5 & 91.8 \\
\hline Spot 48 & 103 & 54478 & 1.5 & 4.9691 & 1.9 & 14.8613 & 4.0 & .5356 & 3.5 & 0.89 & 2765.0 & \begin{tabular}{|l|}
79.7 \\
\end{tabular} & 2806.4 & 38.1 & 2836.3 & 30.3 & 2836.3 & 30.3 & 97.5 \\
\hline Spot 42 & 52 & 247861 & 2.7 & 4.9506 & 1.5 & 15.1867 & 2.7 & 0.5453 & 2.2 & 0.83 & 2805.5 & \begin{tabular}{|l|}
50.2 \\
\end{tabular} & 2827.0 & 25.3 & 2842.4 & 24.2 & 2842.4 & 24.2 & 98.7 \\
\hline Spot 43 & & 206849 & 2.3 & 4.7300 & 1.0 & 15.5924 & 2.1 & 0.5349 & 1.8 & 0.88 & 2762.1 & \begin{tabular}{|l|}
41.0 \\
\end{tabular} & 2852.2 & 19.7 & 2916.4 & 15.7 & 2916.4 & 15.7 & 94.7 \\
\hline Spot 27 & 637 & 136036 & 2.1 & 4.4183 & 1.6 & 17.9996 & 2.9 & 0.5768 & 2.4 & 0.83 & 2935.6 & 56.8 & 2989.7 & 28.1 & 3026.3 & 26.4 & 3026.3 & 26.4 & 97.0 \\
\hline
\end{tabular}




\section{Harvard Analysis (sorted by best age)}

\begin{tabular}{|c|c|c|c|c|c|c|c|c|c|c|c|c|c|c|c|c|c|c|c|}
\hline & & & & & & \multicolumn{2}{|c|}{ Isotope ratios } & & & & & & \multicolumn{3}{|c|}{ Apparent ages (Ma) } & & & & \\
\hline Analysis & $\mathrm{U}$ & $206 \mathrm{~Pb}$ & $\mathrm{U} / \mathrm{Th}$ & $206 \mathrm{~Pb}^{*}$ & \pm & 207Pb* & \pm & $206 \mathrm{~Pb}^{*}$ & \pm & error & $206 \mathrm{~Pb}^{\star}$ & \pm & $207 \mathrm{~Pb}^{*}$ & \pm & $206 \mathrm{~Pb}^{*}$ & \pm & Best age & \pm & Conc \\
\hline & (ppm) & $204 \mathrm{~Pb}$ & & $207 \mathrm{~Pb}^{*}$ & $(\%)$ & $235 U^{*}$ & $(\%)$ & $238 \mathrm{U}$ & $(\%)$ & corr. & \begin{tabular}{|l|}
$238 U^{*}$ \\
\end{tabular} & (Ma) & $235 \mathrm{U}$ & (Ma) & $207 \mathrm{~Pb}^{\star}$ & $(\mathrm{Ma})$ & (Ma) & (Ma) & $(\%)$ \\
\hline & & & & & & & & & & & & & & & & & & & \\
\hline & & & & & & & & & & & & & & & & & & & \\
\hline Spot 29 & 797 & 124647 & 4.1 & 5.5092 & 1.2 & 11.9542 & 3.0 & 0.4776 & 2.8 & 0.92 & 2517.0 & 58.7 & 2600.8 & 28.5 & 2666.7 & 19.2 & 666.7 & 19.2 & 94.4 \\
\hline Spot 31 & 492 & 762073 & 1.4 & 5.5052 & 1.2 & \begin{tabular}{|l|}
12.6961 \\
\end{tabular} & 2.5 & 0.5069 & 2.2 & 0.87 & 2643.5 & 47.0 & 2657.4 & 23.5 & 2667.9 & 20.4 & 2667.9 & 20.4 & \\
\hline Spot 4 & 425 & 299464 & 6.0 & 5.4930 & 0.9 & \begin{tabular}{|l|}
12.3795 \\
\end{tabular} & 1.6 & 0.4932 & \begin{tabular}{|l|}
1.3 \\
\end{tabular} & 0.83 & 2584.5 & 27.3 & 2633.6 & 14.6 & 2671.6 & 14.5 & 2671.6 & 14.5 & 96.7 \\
\hline Spot 25 & 283 & 238927 & 14.6 & 5.4909 & 1.3 & \begin{tabular}{|l|}
12.2594 \\
\end{tabular} & 2.6 & 0.4882 & \begin{tabular}{|l|}
2.2 \\
\end{tabular} & 0.85 & 2563.0 & 46.4 & 2624.5 & 24.2 & \begin{tabular}{|l|}
2672.3 \\
\end{tabular} & 22.2 & 2672.3 & 22.2 & 95.9 \\
\hline Spot 22 & 214 & 68492 & 3.0 & 5.4882 & 1.3 & \begin{tabular}{|l|}
12.9109 \\
\end{tabular} & 2.5 & 0.5139 & \begin{tabular}{|l|}
2.2 \\
\end{tabular} & 0.86 & 2673.3 & 47.7 & 2673.2 & 23.9 & 2673.1 & 21.6 & 2673.1 & 21.6 & 100.0 \\
\hline Spot 50 & 474 & 91805 & 2.5 & 5.4862 & 1.1 & 12.1663 & 2.1 & 0.4841 & 1.8 & 0.85 & 2545.1 & 37.5 & 2617.3 & 19.6 & 2673.7 & 17.9 & 2673.7 & 17.9 & 95.2 \\
\hline Spot 12 & 66 & 158850 & 4.0 & 5.4834 & 1.4 & 12.5616 & 2.5 & 0.4996 & 2.1 & 0.84 & 2611.9 & 45.7 & 2647.3 & 23.7 & \begin{tabular}{|l|}
2674.5 \\
\end{tabular} & 22.5 & 2674.5 & 22.5 & 97.7 \\
\hline Spot 8 & 464 & 94372 & 2.0 & 5.4727 & 0.8 & \begin{tabular}{|l|}
13.0424 \\
\end{tabular} & 1.4 & \begin{tabular}{l|l}
0.5177 \\
\end{tabular} & \begin{tabular}{|l|}
1.2 \\
\end{tabular} & 0.83 & 2689.3 & 26.5 & 2682.7 & 13.7 & \begin{tabular}{|l|}
2677.8 \\
\end{tabular} & 13.3 & 2677.8 & 13.3 & 100.4 \\
\hline Spot 48 & 1112 & 150157 & 3.4 & 5.4471 & 1.8 & 12.9648 & 3.7 & \begin{tabular}{l|l}
0.5122 \\
\end{tabular} & 3.2 & 0.87 & 2666.0 & 69.9 & 2677.1 & 34.8 & 2685.5 & 30.6 & 35.5 & 30.6 & 99.3 \\
\hline Spot 17 & 132 & 411345 & 2.3 & 5.4428 & 1.5 & \begin{tabular}{|l|}
13.3057 \\
\end{tabular} & 2.6 & 0.5252 & \begin{tabular}{|l|}
2.1 \\
\end{tabular} & 0.82 & 2721.4 & 47.7 & 2701.6 & 24.7 & 2686.8 & 24.5 & 2686.8 & 24.5 & 101.3 \\
\hline Spot 35 & 781 & \begin{tabular}{|l|}
2373289 \\
\end{tabular} & 1.4 & 5.4399 & 1.1 & \begin{tabular}{|l|}
12.6365 \\
\end{tabular} & 2.2 & \begin{tabular}{l|l}
0.4986 \\
\end{tabular} & \begin{tabular}{|l|}
1.9 \\
\end{tabular} & 0.86 & 2607.6 & 40.3 & 2652.9 & 20.7 & \begin{tabular}{|l|}
2687.7 \\
\end{tabular} & 18.8 & 2687.7 & 18.8 & 97.0 \\
\hline Spot 33 & 173 & 100882 & 1.2 & 5.4373 & 1.2 & 12.9033 & 2.4 & 0.5088 & 2.1 & 0.87 & 2651.7 & 45.1 & 2672.6 & 22.5 & 2688.5 & 19.6 & 38.5 & 19.6 & 98.6 \\
\hline Spot 10 & 498 & 491547 & 35.1 & 5.4300 & 1.4 & \begin{tabular}{|l|}
12.9089 \\
\end{tabular} & 2.4 & 0.5084 & 1.9 & 0.80 & 2649.7 & 40.7 & 2673.0 & 22.2 & \begin{tabular}{|l|}
2690.7 \\
\end{tabular} & 23.6 & 90.7 & 23.6 & 98.5 \\
\hline Spot 44 & 999 & 637407 & 4.6 & 5.4251 & 1.4 & \begin{tabular}{|l|}
13.6858 \\
\end{tabular} & 2.6 & 0.5385 & \begin{tabular}{|l|}
2.2 \\
\end{tabular} & 0.85 & 2777.1 & 50.6 & 2728.2 & 25.0 & \begin{tabular}{|l|}
2692.2 \\
\end{tabular} & 23.0 & 2692.2 & 23.0 & 103.2 \\
\hline Spot 42 & 441 & 211186 & 1.8 & 5.4225 & 1.3 & \begin{tabular}{|l|}
13.0601 \\
\end{tabular} & 2.6 & 0.5136 & \begin{tabular}{|l|}
2.3 \\
\end{tabular} & 0.87 & 2672.1 & 49.4 & 2684.0 & 24.4 & \begin{tabular}{|l|}
2693.0 \\
\end{tabular} & 20.9 & 93.0 & 20.9 & 99.2 \\
\hline Spot 46 & 211 & 277095 & 2.1 & 5.4202 & 1.4 & \begin{tabular}{|l|}
13.0577 \\
\end{tabular} & 2.8 & \begin{tabular}{l|l}
0.5133 \\
\end{tabular} & \begin{tabular}{|l|}
2.5 \\
\end{tabular} & 0.87 & 2670.7 & 53.9 & 2683.8 & 26.6 & \begin{tabular}{|l|}
2693.7 \\
\end{tabular} & 22.5 & 93.7 & 22.5 & 99.1 \\
\hline Spot 21 & 79 & 58307 & 1.8 & 5.4150 & 1.2 & 13.2343 & 2.1 & \begin{tabular}{l|l}
0.5198 \\
\end{tabular} & 1.7 & 0.82 & 2698.1 & 38.4 & 2696.5 & 20.1 & 2695.3 & 20.3 & 2695.3 & 20.3 & 100.1 \\
\hline Spot 11 & 203 & 84803 & 1.5 & 5.4135 & 1.2 & \begin{tabular}{|l|}
12.9140 \\
\end{tabular} & 1.9 & 0.5070 & 1.5 & 0.79 & 2644.0 & 33.4 & 2673.4 & 18.3 & \begin{tabular}{|l|}
2695.7 \\
\end{tabular} & 19.6 & 2695.7 & 19.6 & 98.1 \\
\hline Spot 47 & 101 & 153882 & 1.7 & 5.4115 & 1.4 & 13.5142 & 2.6 & 0.5304 & 2.2 & 0.84 & 2743.2 & 48.6 & 2716.3 & 24.4 & 2696.3 & 22.9 & 6.3 & 22.9 & 101.7 \\
\hline Spot 1 & 445 & 77566 & 0.8 & 5.3931 & 1.1 & 12.9712 & 2.0 & 0.5074 & 1.6 & 0.82 & 2645.3 & 34.9 & 2677.6 & 18.5 & 2702.0 & 18.6 & 2702.0 & 18.6 & 97.9 \\
\hline Spot 15 & 262 & 77739 & 10.0 & 5.3923 & 1.1 & \begin{tabular}{|l|}
12.8330 \\
\end{tabular} & 1.9 & \begin{tabular}{l|l|}
0.5019 \\
\end{tabular} & \begin{tabular}{|l|}
1.6 \\
\end{tabular} & 0.84 & 2621.9 & 34.9 & 2667.5 & 18.3 & \begin{tabular}{|l|}
2702.2 \\
\end{tabular} & 17.6 & 2702.2 & 17.6 & 97.0 \\
\hline Spot 5 & 171 & 98907 & 7.5 & 5.3851 & 1.0 & 13.4095 & 2.1 & 237 & 1.9 & 0.88 & 2715.0 & 41.6 & 2708.9 & 20.2 & 2704.4 & 16.9 & 4.4 & 16.9 & 100.4 \\
\hline Spot 32 & 127 & 67331 & 1.0 & 5.3788 & 1.5 & \begin{tabular}{|l|}
13.4232 \\
\end{tabular} & 3.0 & \begin{tabular}{l|}
0.5237 \\
\end{tabular} & 2.6 & 0.87 & 2714.7 & 58.0 & 2709.9 & 28.4 & 2706.3 & 24.4 & 2706.3 & 24.4 & 100.3 \\
\hline Spot 45 & 301 & 71822 & 25.2 & 5.3780 & 1.0 & \begin{tabular}{|l|}
13.8315 \\
\end{tabular} & 2.0 & 395 & \begin{tabular}{|l|}
1.7 \\
\end{tabular} & 0.85 & 2781.3 & 38.8 & 2738.2 & 19.0 & 2706.6 & 17.3 & 2706.6 & 17.3 & 102.8 \\
\hline Spot 49 & 34 & 137381 & 2.1 & 5.3631 & 1.6 & \begin{tabular}{|l|}
13.7090 \\
\end{tabular} & 2.6 & 332 & \begin{tabular}{|l|}
2.1 \\
\end{tabular} & \begin{tabular}{|l|}
0.80 \\
\end{tabular} & 2755.1 & \begin{tabular}{|l|}
46.1 \\
\end{tabular} & 2729.8 & 24.4 & 2711.2 & 25.6 & 1.2 & 25.6 & 101.6 \\
\hline Spot 18 & 77 & 131397 & 2.6 & 5.3571 & 1.4 & \begin{tabular}{|l|}
13.9507 \\
\end{tabular} & 2.5 & \begin{tabular}{l|l}
0.5420 \\
\end{tabular} & \begin{tabular}{|l|}
2.0 \\
\end{tabular} & 0.83 & 2791.9 & 46.4 & 2746.4 & 23.3 & 2713.0 & 22.5 & 2713.0 & 22.5 & 102.9 \\
\hline Spot 6 & 280 & 168556 & 1.2 & 5.3568 & 0.9 & \begin{tabular}{|l|}
13.2607 \\
\end{tabular} & 1.8 & 0.5152 & \begin{tabular}{|l|}
1.6 \\
\end{tabular} & 0.86 & 2678.8 & 34.4 & 2698.4 & 17.2 & \begin{tabular}{|l|}
2713.1 \\
\end{tabular} & 15.1 & 2713.1 & \begin{tabular}{|l|}
15.1 \\
\end{tabular} & 98.7 \\
\hline Spot 34 & 62 & 65206 & 3.0 & 5.3545 & 1.3 & \begin{tabular}{|l|}
14.1061 \\
\end{tabular} & 2.5 & \begin{tabular}{l|l}
0.5478 \\
\end{tabular} & \begin{tabular}{|l|}
2.2 \\
\end{tabular} & 0.86 & 2816.0 & 49.9 & 2756.9 & 24.0 & 2713.8 & 21.0 & 2713.8 & 21.0 & 103.8 \\
\hline Spot 19 & 2154 & 76236 & 2.3 & 5.3504 & 1.7 & \begin{tabular}{|l|}
11.4826 \\
\end{tabular} & 2.9 & \begin{tabular}{l|l}
0.4456 \\
\end{tabular} & 2.3 & 0.82 & 2375.6 & 46.4 & 2563.2 & 26.7 & 2715.1 & 27.3 & 2715.1 & 27.3 & 87.5 \\
\hline Spot 16 & 121 & 726743 & 1.2 & 5.3487 & \begin{tabular}{|l|}
1.0 \\
\end{tabular} & \begin{tabular}{|l|}
13.7681 \\
\end{tabular} & 2.5 & 0.5341 & 2.3 & 0.91 & 2758.7 & 50.9 & 2733.9 & 23.7 & 2715.6 & 17.3 & 2715.6 & 17.3 & 101.6 \\
\hline Spot 28 & 157 & 112745 & 3.5 & 5.3457 & 1.4 & \begin{tabular}{|l|}
13.5619 \\
\end{tabular} & 2.5 & 0.5258 & \begin{tabular}{|l|l|}
2.1 \\
\end{tabular} & 0.84 & 2723.8 & \begin{tabular}{|l|}
47.4 \\
\end{tabular} & 2719.6 & 24.0 & \begin{tabular}{|l|}
2716.5 \\
\end{tabular} & 22.6 & 2716.5 & 22.6 & 100.3 \\
\hline Spot 9 & 303 & 96942 & 4.4 & 5.3189 & 1.2 & \begin{tabular}{|l|}
13.0638 \\
\end{tabular} & 2.2 & 0.5040 & \begin{tabular}{|l|}
1.9 \\
\end{tabular} & 0.84 & 2630.8 & 40.8 & 2684.3 & 21.2 & 2724.8 & 20.0 & 2724.8 & 20.0 & 96.5 \\
\hline Spot 3 & 2663 & 94780 & 2.6 & 5.2978 & 1.1 & \begin{tabular}{|l|}
11.7574 \\
\end{tabular} & 2.2 & \begin{tabular}{l|l}
0.4518 \\
\end{tabular} & \begin{tabular}{|l|}
1.9 \\
\end{tabular} & 0.87 & 2403.1 & 38.8 & 2585.3 & 20.8 & 2731.4 & 17.9 & 2731.4 & 17.9 & 88.0 \\
\hline Spot 30 & 69 & 147398 & 1.1 & 5.2860 & 1.6 & \begin{tabular}{|l|}
13.7369 \\
\end{tabular} & 2.6 & 0.5266 & 2.1 & 0.80 & 2727.3 & 46.5 & 2731.7 & 24.6 & 2735.0 & 25.6 & 2735.0 & 25.6 & 99.7 \\
\hline Spot 13 & 354 & \begin{tabular}{|l|}
5132161 \\
\end{tabular} & 1.5 & 5.2802 & 1.5 & \begin{tabular}{|l|}
13.5066 \\
\end{tabular} & 2.4 & 0.5172 & \begin{tabular}{|l|}
1.9 \\
\end{tabular} & \begin{tabular}{|l|}
0.79 \\
\end{tabular} & 2687.5 & \begin{tabular}{|l|}
41.7 \\
\end{tabular} & 2715.7 & 22.6 & 2736.8 & 23.9 & 2736.8 & 23.9 & 98.2 \\
\hline Spot 20 & 172 & 80043 & 4.5 & 5.2759 & 1.1 & \begin{tabular}{|l|}
13.8409 \\
\end{tabular} & 2.2 & 0.5296 & \begin{tabular}{|l|}
2.0 \\
\end{tabular} & \begin{tabular}{|l|}
0.88 \\
\end{tabular} & 2739.8 & 44.3 & 2738.9 & 21.3 & \begin{tabular}{|l|}
2738.2 \\
\end{tabular} & 17.4 & 2738.2 & 17.4 & 100.1 \\
\hline Spot 43 & 270 & 120346 & 0.7 & 5.2443 & \begin{tabular}{|l|}
1.1 \\
\end{tabular} & \begin{tabular}{|l|}
13.2927 \\
\end{tabular} & 2.6 & 0.5056 & \begin{tabular}{|l|}
2.4 \\
\end{tabular} & \begin{tabular}{|l|}
0.90 \\
\end{tabular} & 2637.8 & 51.4 & 2700.7 & 24.8 & \begin{tabular}{|l|}
2748.0 \\
\end{tabular} & 18.5 & 2748.0 & 18.5 & 96.0 \\
\hline Spot 41 & 877 & 38487 & 5.0 & 5.2368 & 1.2 & \begin{tabular}{|l|}
13.7591 \\
\end{tabular} & 2.8 & 0.5226 & 2.6 & 0.91 & 2710.1 & 56.8 & 2733.3 & 26.7 & 2750.4 & 19.1 & 2750.4 & \begin{tabular}{|l|}
19.1 \\
\end{tabular} & 98.5 \\
\hline Spot 36 & 130 & \begin{tabular}{|l|}
5100997 \\
\end{tabular} & 1.0 & 5.2290 & 1.6 & \begin{tabular}{|l|}
14.3577 \\
\end{tabular} & 2.7 & 0.5445 & \begin{tabular}{|l|}
2.2 \\
\end{tabular} & \begin{tabular}{|l|}
0.81 \\
\end{tabular} & 2802.3 & 49.9 & 2773.6 & 25.6 & 2752.9 & 25.8 & 2752.9 & 25.8 & 101.8 \\
\hline Spot 24 & 1082 & 170413 & 16.0 & 5.1875 & 1.3 & 13.5651 & 2.6 & 0.5104 & \begin{tabular}{|l|}
2.2 \\
\end{tabular} & 0.87 & 2658.2 & 48.7 & 2719.8 & 24.4 & \begin{tabular}{|l|}
2765.9 \\
\end{tabular} & 21.3 & 2765.9 & 21.3 & 96.1 \\
\hline Spot 27 & 104 & 85344 & 1.6 & 5.1531 & 1.5 & \begin{tabular}{|l|}
14.0141 \\
\end{tabular} & 2.6 & 0.5238 & 2.1 & 0.83 & 2715.1 & 47.5 & 2750.7 & 24.6 & \begin{tabular}{|l|}
2776.9 \\
\end{tabular} & 23.8 & 2776.9 & 23.8 & 97.8 \\
\hline Spot 2 & 50 & 40815 & 0.4 & 5.1204 & 1.0 & 13.5061 & 2.4 & 0.5016 & 2.1 & 0.91 & 2620.5 & 46.3 & 2715.7 & 22.4 & 2787.3 & 16.5 & 2787.3 & 16.5 & 94.0 \\
\hline Spot 39 & 344 & 29337 & 3.9 & 5.0596 & 1.5 & \begin{tabular}{|l|}
12.3557 \\
\end{tabular} & 2.4 & 0.4534 & \begin{tabular}{|l|}
1.9 \\
\end{tabular} & \begin{tabular}{|l|}
0.78 \\
\end{tabular} & 2410.4 & 38.0 & 2631.8 & 22.6 & 2806.8 & 24.4 & 2806.8 & 24.4 & 85.9 \\
\hline Spot 40 & 689 & 266079 & 1.9 & 5.0012 & 1.3 & \begin{tabular}{|l|}
15.0550 \\
\end{tabular} & 2.7 & \begin{tabular}{l|}
0.5461 \\
\end{tabular} & \begin{tabular}{|l|}
2.3 \\
\end{tabular} & \begin{tabular}{|l|}
0.86 \\
\end{tabular} & 2808.8 & \begin{tabular}{|l|}
52.7 \\
\end{tabular} & 2818.7 & 25.5 & \begin{tabular}{|l|}
2825.8 \\
\end{tabular} & 22.0 & 2825.8 & 22.0 & 99.4 \\
\hline Spot 14 & 672 & 98875 & 5.5 & 4.9883 & 0.9 & \begin{tabular}{|l|}
14.9612 \\
\end{tabular} & 2.0 & 0.5413 & \begin{tabular}{|l|}
1.8 \\
\end{tabular} & 0.90 & 2788.8 & 39.7 & 2812.8 & 18.6 & 2830.0 & 13.9 & 2830.0 & 13.9 & 98.5 \\
\hline Spot 38 & 329 & 92106 & 5.2 & \begin{tabular}{|l|}
4.7549 \\
\end{tabular} & 1.7 & \begin{tabular}{|l|}
16.1603 \\
\end{tabular} & 3.1 & 0.5573 & 2.6 & 0.84 & 2855.4 & 60.3 & 2886.3 & 29.8 & 2907.9 & 27.4 & 2907.9 & \begin{tabular}{|l|}
27.4 \\
\end{tabular} & 98.2 \\
\hline
\end{tabular}




\section{Tiskilwa Analysis (sorted by best age)}

\begin{tabular}{|c|c|c|c|c|c|c|c|c|c|c|c|c|c|c|c|c|c|c|c|}
\hline & & & & & & \multicolumn{2}{|c|}{ Isotope ratios } & & & & & & \multicolumn{3}{|c|}{ Apparent ages (Ma) } & & & & \\
\hline Analysis & $\bar{U}$ & $206 \mathrm{~Pb}$ & $\mathrm{U} / \mathrm{Th}$ & $206 \mathrm{~Pb}^{*}$ & \pm & $207 \mathrm{~Pb}^{*}$ & \pm & $206 \mathrm{~Pb}^{*}$ & \pm & error & $206 \mathrm{~Pb}^{*}$ & \pm & 207Pb* & \pm & 206Pb* & \pm & Bes & \pm & Conc \\
\hline & (ppm) & $204 \mathrm{~Pb}$ & & 207 $\mathrm{Pb}^{*}$ & $(\%)$ & $235 U^{*}$ & $(\%)$ & $238 \mathrm{U}$ & $(\%)$ & corr. & $238 U^{*}$ & (Ma) & $235 \mathrm{U}$ & $(\mathrm{Ma})$ & $207 \mathrm{~Pb}^{*}$ & (Ma) & (Ma) & $(\mathrm{Ma})$ & $(\%)$ \\
\hline & & & & & & & & & & & & & & & & & & & \\
\hline Spot 47 & 259 & 7604 & 129 & 9959 & 20 & 5782 & 38 & 03338 & 3 ? & 085 & 3566 & 523 & 256.4 & 337 & 2631 & 351 & & & \\
\hline Spot 28 & 224 & 91615 & 7.2 & 5.6745 & 1.3 & \begin{tabular}{|l|}
10.9166 \\
\end{tabular} & 2.4 & 0.4493 & 2.0 & 0.83 & 2392.0 & 39.7 & 2516.1 & 22.2 & 2617.7 & 22.1 & 2617.7 & 22.1 & 91.4 \\
\hline Spot 15 & 303 & 34103 & 1.4 & 5.6536 & 2.5 & 12.3640 & 3.5 & 0.5070 & 2.4 & 0.70 & 2643.7 & 52.2 & 2632.4 & $\begin{array}{l}2 L .4 \\
32.4\end{array}$ & \begin{tabular}{|l|}
2623.8 \\
\end{tabular} & \begin{tabular}{|l|}
41.2 \\
\end{tabular} & 2623.8 & 41.2 & \begin{tabular}{|l|l|}
01.7 \\
100.8
\end{tabular} \\
\hline Spot 4 & 23 & 38017 & 2.8 & \begin{tabular}{|l|}
5.6185 \\
\end{tabular} & 1.5 & \begin{tabular}{|l|}
12.3875 \\
\end{tabular} & 2.6 & 0.5048 & 2.1 & 0.81 & 2634.3 & 45.9 & 2634.2 & 24.6 & 2634.2 & 25.5 & 2634.2 & 25.5 & 100.0 \\
\hline Spot 29 & 317 & 219963 & 1.9 & 5.5700 & 1.2 & \begin{tabular}{|l|}
13.2312 \\
\end{tabular} & 2.5 & 0.5345 & 2.2 & 0.88 & 2760.4 & 48.7 & 2696.3 & 23.3 & 2648.5 & \begin{tabular}{|l|}
19.4 \\
\end{tabular} & 2648.5 & 19.4 & 104.2 \\
\hline Spot 16 & 22 & 61278 & 3.6 & 5.5360 & 1.5 & 13.4077 & 2.7 & 0.5383 & 2.2 & 0.82 & 2776.5 & 49.5 & 2708.8 & 25.4 & 2658.7 & 25.6 & 2658.7 & 25.6 & 104.4 \\
\hline Spot 25 & 60 & 187378 & 1.3 & 5.5150 & 1.1 & \begin{tabular}{|l|}
13.1443 \\
\end{tabular} & 2.1 & 0.5257 & 1.7 & 0.83 & 2723.5 & 37.9 & 2690.1 & \begin{tabular}{|l|}
19.4 \\
\end{tabular} & 2665.0 & 18.8 & 2665.0 & 18.8 & 102.2 \\
\hline Spot 50 & 172 & 133689 & 3.1 & 5.5047 & 1.5 & 13.1655 & 2.4 & 0.5256 & 1.9 & 0.79 & 2722.9 & 42.5 & 2691.6 & 22.8 & 2668.1 & \begin{tabular}{|l|}
24.4 \\
\end{tabular} & 2668.1 & 24.4 & 102.1 \\
\hline Spot 17 & 252 & 63878 & 2.4 & 5.5038 & 1.2 & 13.0062 & 2.0 & 0.5192 & 1.6 & 0.80 & 2695.7 & 35.7 & 2680.1 & 19.1 & \begin{tabular}{|l|}
2668.4 \\
\end{tabular} & 20.1 & 2668.4 & 20.1 & 101.0 \\
\hline Spot 10 & 183 & 246104 & 2.1 & 5.5023 & \begin{tabular}{|l|}
1.4 \\
\end{tabular} & \begin{tabular}{|l|}
12.8416 \\
\end{tabular} & 2.5 & 0.5125 & 2.1 & 0.83 & 2667.1 & 46.1 & 2668.1 & 23.9 & \begin{tabular}{|l|}
2668.8 \\
\end{tabular} & 23.5 & 2668.8 & 23.5 & 99.9 \\
\hline Spot 45 & 428 & 8209787 & 5.0 & 5.4900 & 1.0 & 13.2369 & 2.1 & 0.5271 & 1.9 & 0.89 & 2729.0 & 42.7 & 2696.7 & 20.3 & 2672.5 & \begin{tabular}{|l|}
16.0 \\
\end{tabular} & 2672.5 & 16.0 & 102.1 \\
\hline Spot 44 & 393 & 97774 & 6.6 & 5.4790 & 1.0 & \begin{tabular}{|l|}
13.0450 \\
\end{tabular} & 2.5 & 0.5184 & 2.3 & 0.91 & 2692.3 & \begin{tabular}{|l|}
49.7 \\
\end{tabular} & 2682.9 & 23.3 & 2675.8 & \begin{tabular}{|l|}
16.8 \\
\end{tabular} & 2675.8 & 16.8 & 100.6 \\
\hline Spot 37 & 114 & 81772 & 5.8 & 5.4687 & 1.4 & 13.2322 & 2.7 & 0.5248 & 2.3 & 0.86 & 2719.6 & 51.0 & 2696.4 & 25.3 & 2679.0 & \begin{tabular}{|l|}
22.8 \\
\end{tabular} & 2679.0 & 22.8 & 101.5 \\
\hline Spot 26 & 634 & 169520 & 4.3 & \begin{tabular}{|l|}
5.4642 \\
\end{tabular} & \begin{tabular}{|l|}
1.1 \\
\end{tabular} & \begin{tabular}{|l|}
12.9843 \\
\end{tabular} & 1.9 & 0.5146 & 1.5 & 0.81 & 2676.1 & 33.0 & 2678.5 & 17.6 & 2680.3 & \begin{tabular}{|l|}
18.3 \\
\end{tabular} & 2680.3 & 18.3 & 99.8 \\
\hline Spot 30 & 28 & 25868 & 3.7 & 5.4610 & 1.5 & 13.3142 & 2.5 & 0.5273 & 2.0 & 0.81 & 2730.2 & \begin{tabular}{|l|}
45.6 \\
\end{tabular} & 2702.2 & 23.8 & \begin{tabular}{|l|}
2681.3 \\
\end{tabular} & \begin{tabular}{|l|}
24.1 \\
\end{tabular} & 2681.3 & 24.1 & 101.8 \\
\hline Spot 46 & 300 & 149582 & 2.9 & 5.4512 & 1.0 & 13.2222 & 1.9 & 0.5227 & 1.6 & 0.85 & 2710.8 & 35.6 & 2695.6 & 17.9 & \begin{tabular}{|l|}
2684.3 \\
\end{tabular} & 16.5 & 2684.3 & 16.5 & 101.0 \\
\hline Spot 20 & 489 & 401566 & 5.6 & 5.4504 & 1.2 & 13.2822 & 2.3 & 0.5250 & 2.0 & 0.85 & 2720.6 & \begin{tabular}{|l|}
43.3 \\
\end{tabular} & 2699.9 & 21.6 & 2684.5 & \begin{tabular}{|l|}
19.8 \\
\end{tabular} & 2684.5 & 19.8 & 101.3 \\
\hline Spot 49 & 286 & 254757 & 0.6 & 5.4355 & 1.2 & 13.4880 & 2.1 & 0.5317 & 1.8 & 0.83 & 2748.7 & 39.4 & 2714.4 & 20.0 & 2689.0 & \begin{tabular}{|l|}
19.5 \\
\end{tabular} & 2689.0 & 19.5 & 102.2 \\
\hline Spot 19 & 560 & 607871 & 5.3 & 5.4327 & 0.9 & 13.1147 & 2.1 & 0.5167 & 1.9 & 0.90 & 2685.3 & \begin{tabular}{|l|}
41.9 \\
\end{tabular} & 2687.9 & 20.1 & \begin{tabular}{|l|}
2689.9 \\
\end{tabular} & \begin{tabular}{|l|}
15.7 \\
\end{tabular} & 2689.9 & \begin{tabular}{|l|}
15.7 \\
\end{tabular} & 99.8 \\
\hline Spot 34 & 445 & 175288 & 4.4 & 5.4289 & 0.9 & 13.1434 & 2.1 & 0.5175 & 1.9 & 0.90 & 2688.6 & 41.2 & 2690.0 & 19.6 & \begin{tabular}{|l|}
2691.0 \\
\end{tabular} & \begin{tabular}{|l|}
15.0 \\
\end{tabular} & 2691.0 & 15.0 & 99.9 \\
\hline Spot 3 & 991 & 27879 & 1.4 & 5.4161 & 1.0 & 11.8055 & 2.5 & 0.4637 & 2.3 & 0.91 & 2456.0 & 46.4 & 2589.1 & 23.4 & 2694.9 & 17.3 & 2694.9 & 17.3 & 91.1 \\
\hline Spot 31 & 73 & 66920 & 4.0 & 5.4160 & 0.9 & 13.8361 & 2.0 & 0.5435 & 1.8 & 0.90 & 2798.0 & 41.1 & 2738.6 & 19.0 & 2695.0 & \begin{tabular}{|l|}
14.4 \\
\end{tabular} & 2695.0 & 14.4 & 103.8 \\
\hline Spot 35 & 384 & 54966 & 6.8 & \begin{tabular}{|l|}
5.4025 \\
\end{tabular} & 1.5 & \begin{tabular}{|l|}
12.9159 \\
\end{tabular} & 3.1 & 0.5061 & \begin{tabular}{|l|}
2.7 \\
\end{tabular} & 0.88 & 2639.9 & 59.0 & 2673.5 & 29.3 & \begin{tabular}{|l|}
2699.1 \\
\end{tabular} & \begin{tabular}{|l|}
24.9 \\
\end{tabular} & 2699.1 & 24.9 & \begin{tabular}{|l}
07.8 \\
97.8
\end{tabular} \\
\hline Spot 12 & 106 & 52315 & 1.2 & 5.4007 & 1.4 & \begin{tabular}{|l|}
13.9572 \\
\end{tabular} & 2.7 & 0.5467 & 2.4 & 0.86 & 2811.4 & 53.6 & 2746.8 & 25.9 & 2699.6 & 23.1 & 2699.6 & 23.1 & 104.1 \\
\hline Spot 9 & 309 & 107030 & 2.1 & 5.3972 & 1.1 & 13.1354 & 1.8 & 0.5142 & 1.4 & 0.79 & 2674.4 & 30.8 & 2689.4 & 16.8 & \begin{tabular}{|l|}
2700.7 \\
\end{tabular} & \begin{tabular}{|l|}
18.1 \\
\end{tabular} & 2700.7 & 18.1 & 99.0 \\
\hline Spot 7 & 493 & 207324 & 4.4 & \begin{tabular}{|l|}
5.3922 \\
\end{tabular} & 1.1 & 13.6864 & 2.2 & 0.5352 & 1.9 & 0.86 & 2763.5 & 41.8 & 2728.3 & 20.6 & \begin{tabular}{|l|}
2702.2 \\
\end{tabular} & 18.5 & 2702.2 & 18.5 & 102.3 \\
\hline Spot 14 & 257 & 56489 & 3.7 & 5.3790 & 0.9 & 13.3752 & 2.3 & 0.5218 & 2.1 & 0.91 & 2706.8 & 46.3 & 2706.5 & 21.7 & 2706.3 & \begin{tabular}{|l|}
15.3 \\
\end{tabular} & 2706.3 & 15.3 & 100.0 \\
\hline Spot 6 & 810 & 67520 & 14.0 & \begin{tabular}{|l|}
5.3789 \\
\end{tabular} & 1.0 & 13.4488 & 2.0 & 0.5247 & 1.7 & 0.87 & 2718.9 & 38.3 & 2711.7 & 18.9 & \begin{tabular}{|l|}
2706.3 \\
\end{tabular} & \begin{tabular}{|l|}
16.5 \\
\end{tabular} & 2706.3 & 16.5 & 100.5 \\
\hline Spot 11 & 600 & 70298 & 4.0 & \begin{tabular}{|l|}
5.3758 \\
\end{tabular} & 1.4 & 12.1873 & 3.2 & 0.4752 & 2.9 & 0.89 & 2506.2 & 59.5 & 2618.9 & 30.1 & \begin{tabular}{|l|}
2707.3 \\
\end{tabular} & \begin{tabular}{|l|}
23.8 \\
\end{tabular} & 2707.3 & 23.8 & 92.6 \\
\hline Spot 41 & 527 & 213852 & 3.5 & 5.3711 & 1.2 & \begin{tabular}{|l|}
13.3172 \\
\end{tabular} & 2.8 & 0.5188 & 2.5 & 0.90 & 2694.0 & 55.0 & 2702.4 & 26.1 & \begin{tabular}{|l|}
2708.7 \\
\end{tabular} & \begin{tabular}{|l|}
19.5 \\
\end{tabular} & 2708.7 & 19.5 & 99.5 \\
\hline Spot 21 & 138 & 119846 & 13.0 & 5.3660 & 1.3 & 13.0529 & 2.8 & 0.5080 & 2.4 & 0.88 & 2648.1 & 52.9 & 2683.5 & 26.2 & 2710.3 & 21.9 & 2710.3 & 21.9 & 97.7 \\
\hline Spot 24 & 1090 & 99967 & 2.9 & 5.3545 & 0.9 & \begin{tabular}{|l|}
13.2181 \\
\end{tabular} & 2.0 & 0.5133 & 1.7 & 0.89 & 2670.8 & 38.2 & 2695.4 & 18.5 & \begin{tabular}{|l|}
2713.8 \\
\end{tabular} & \begin{tabular}{|l|}
14.6 \\
\end{tabular} & 2713.8 & 14.6 & 98.4 \\
\hline Spot 36 & 217 & 62743 & 3.7 & 5.3461 & 1.1 & 14.0673 & 2.2 & 0.5454 & 1.9 & 0.86 & 2806.2 & \begin{tabular}{|l|}
42.3 \\
\end{tabular} & 2754.3 & 20.5 & \begin{tabular}{|l|}
2716.4 \\
\end{tabular} & \begin{tabular}{|l|}
18.1 \\
\end{tabular} & 2716.4 & 18.1 & 103.3 \\
\hline Spot 27 & 704 & 555479 & 1.0 & 5.3451 & 1.1 & 13.5123 & 2.1 & 0.5238 & 1.8 & 0.85 & 2715.4 & 39.9 & 2716.1 & 20.1 & \begin{tabular}{|l|}
2716.7 \\
\end{tabular} & \begin{tabular}{|l|}
18.5 \\
\end{tabular} & 2716.7 & 18.5 & 99.9 \\
\hline Spot 8 & 40 & 42489 & 0.9 & 5.3288 & 0.9 & 14.1643 & 2.3 & 0.5474 & 2.1 & 0.91 & 2814.4 & 48.0 & 2760.8 & 21.9 & \begin{tabular}{|l|}
2721.8 \\
\end{tabular} & \begin{tabular}{|l|}
15.5 \\
\end{tabular} & 2721.8 & 15.5 & 103.4 \\
\hline Spot 42 & 199 & 68151 & 10.5 & 5.3268 & 1.3 & 13.8950 & 2.5 & 0.5368 & 2.2 & 0.86 & 2770.1 & 48.9 & 2742.6 & 23.8 & \begin{tabular}{|l|}
2722.4 \\
\end{tabular} & 21.0 & 2722.4 & 21.0 & 101.8 \\
\hline Spot 43 & 733 & 219391 & 51.0 & 5.3086 & 1.2 & \begin{tabular}{|l|}
13.4248 \\
\end{tabular} & 2.7 & 0.5169 & 2.4 & 0.89 & 2685.9 & 53.4 & 2710.0 & 25.8 & 2728.0 & 20.3 & 2728.0 & 20.3 & 98.5 \\
\hline Spot 32 & 325 & 1258224 & 3.6 & 5.2864 & 1.2 & 13.4567 & 2.5 & 0.5159 & 2.2 & 0.87 & 2681.9 & 47.2 & 2712.3 & 23.3 & 2734.9 & \begin{tabular}{|l|}
19.7 \\
\end{tabular} & 2734.9 & 19.7 & 98.1 \\
\hline Spot 1 & 70 & 87600 & 2.7 & 5.2739 & 1.5 & 12.1098 & 2.8 & 0.4632 & 2.4 & 0.85 & 2453.7 & 48.5 & 2612.9 & 26.3 & 2738.8 & 24.5 & 2738.8 & 24.5 & 89.6 \\
\hline Spot 23 & 381 & 85081 & 1.3 & 5.2036 & 0.9 & \begin{tabular}{|l|}
13.4757 \\
\end{tabular} & 2.1 & 0.5086 & 1.9 & 0.91 & 2650.6 & 42.1 & 2713.6 & 20.2 & 2760.8 & 14.9 & 2760.8 & 14.9 & 96.0 \\
\hline Spot 48 & 1046 & 395097 & 1.5 & 5.1868 & 1.1 & 13.0495 & 2.0 & 0.4909 & 1.7 & 0.83 & 2574.6 & 35.3 & 2683.2 & 18.8 & \begin{tabular}{|l|}
2766.1 \\
\end{tabular} & \begin{tabular}{|l|}
18.1 \\
\end{tabular} & 2766.1 & 18.1 & 93.1 \\
\hline Spot 39 & 103 & 240648 & 2.2 & 4.8084 & 1.1 & 16.4924 & 2.0 & 0.5752 & 1.7 & 0.85 & 2928.9 & \begin{tabular}{|l|}
40.3 \\
\end{tabular} & 2905.8 & 19.3 & 2889.8 & \begin{tabular}{|l|}
17.2 \\
\end{tabular} & 2889.8 & 17.2 & 101.4 \\
\hline Spot 13 & 642 & 435699 & 3.3 & 4.6347 & 1.3 & 17.4127 & 2.5 & 0.5853 & 2.1 & 0.85 & 2970.4 & 51.1 & 2957.9 & 24.3 & 2949.3 & 21.8 & 2949.3 & 21.8 & 100.7 \\
\hline Spot 2 & 620 & 214768 & 2.3 & 4.6162 & 1.1 & \begin{tabular}{|l|}
17.3981 \\
\end{tabular} & 2.4 & 0.5825 & 2.1 & 0.88 & 2958.9 & 50.2 & 2957.0 & 23.0 & 2955.8 & \begin{tabular}{|l|}
18.2 \\
\end{tabular} & 2955.8 & 18.2 & 100.1 \\
\hline Spot 38 & 889 & 188810 & 8.2 & 4.5530 & 1.1 & 15.2679 & 2.4 & 0.5042 & 2.1 & 0.88 & 2631.7 & 45.1 & 2832.1 & 22.5 & 2978.0 & \begin{tabular}{|l|}
17.9 \\
\end{tabular} & 2978.0 & 17.9 & 88.4 \\
\hline Spot 40 & 613 & 54951 & 1.5 & 4.5292 & 1.5 & \begin{tabular}{|l|}
15.9057 \\
\end{tabular} & 2.7 & 0.5225 & 2.2 & 0.84 & 2709.7 & 49.2 & 2871.1 & 25.4 & \begin{tabular}{|l|}
2986.5 \\
\end{tabular} & 23.5 & 2986.5 & 23.5 & 90.7 \\
\hline
\end{tabular}




\section{Putnam Analysis (sorted by best age)}

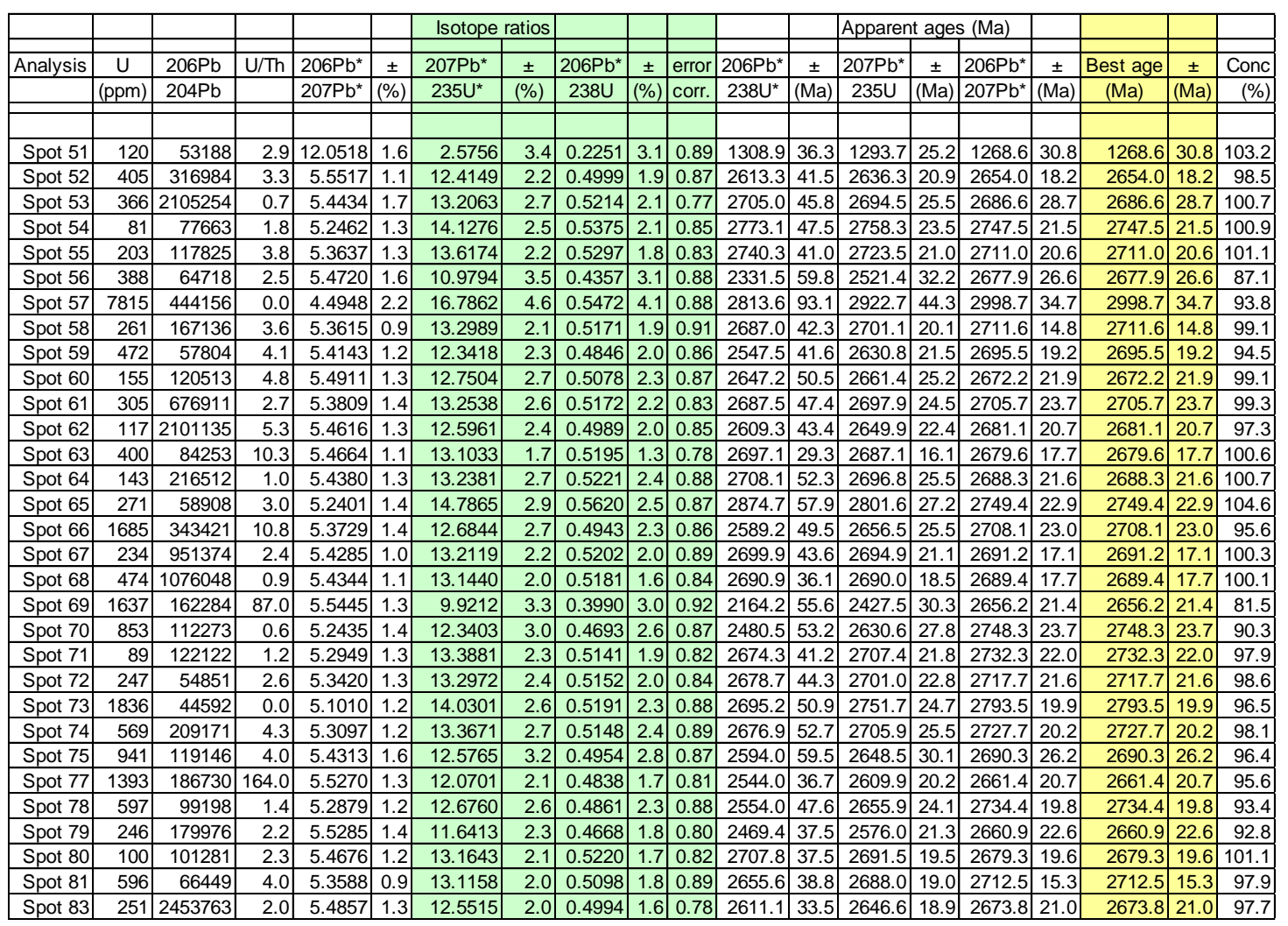




\section{Genoa Analysis (sorted by best age)}

\begin{tabular}{|c|c|c|c|c|c|c|c|c|c|c|c|c|c|c|c|c|c|c|c|}
\hline & & & & & & \multicolumn{2}{|c|}{ Isotope ratios } & & & & & & \multicolumn{3}{|c|}{ Apparent ages (Ma) } & & & & \\
\hline is & U & $6 \mathrm{~Pb}$ & Th & $206 \mathrm{~Pb}^{*}$ & \pm & $77 \mathrm{~Pb}^{*}$ & \pm & $06 \mathrm{~Pb}^{\star}$ & \pm & error & $206 \mathrm{~Pb}^{*}$ & \pm & $207 \mathrm{~Pb}^{*}$ & \pm & $\overline{06 \mathrm{~Pb}^{\star}}$ & \pm & ge & \pm & Conc \\
\hline & (ppm) & $4 \mathrm{~Pb}$ & & $207 \mathrm{~Pb}^{\star}$ & $(\%)$ & $235 \mathrm{U}^{*}$ & $(\%)$ & $238 U$ & $(\%)$ & corr. & $238 U^{*}$ & (Ma) & $235 \mathrm{U}$ & (Ma) & $207 \mathrm{~Pb}^{\star}$ & $(\mathrm{Ma})$ & 4 & (Ma) & \\
\hline & & & & & & & & & & & & & & & & & & & \\
\hline & & & & & & & & & & & & & & & & & & & \\
\hline Spot 13 & 275 & 1075 & .8 & 6346 & 1.1 & & 0 & & 7 & 0.83 & & 31.3 & 2439.8 & 8.6 & & 18.8 & & 18.8 & \\
\hline Spot 45 & 708 & 1435 & 4.7 & 5.6248 & 1.3 & 1.7917 & 2.3 & 4810 & \begin{tabular}{|l|}
1.9 \\
\end{tabular} & 0.84 & 531.8 & 40.3 & 2588.0 & 21.5 & 2632.3 & 20.9 & 332.3 & 20.9 & 0.5 \\
\hline Spot 27 & 310 & 3000 & 1.1 & 5.5217 & 1.0 & 12.5192 & 1.9 & 5014 & 1.6 & 0.85 & 619.6 & 33.8 & 2644.2 & 17.4 & 2663.0 & 16.4 & 363.0 & 16.4 & 8.4 \\
\hline Spot 32 & 141 & 183196 & 1.5 & 5.4677 & 1.2 & 12.5951 & 2.4 & .4995 & 2.1 & 0.87 & 611.5 & 45.5 & 2649.9 & 22.9 & 2679.3 & 19.8 & & \begin{tabular}{|c|}
19.8 \\
\end{tabular} & 7.5 \\
\hline Spot 31 & 112 & 102020 & 1.3 & \begin{tabular}{|l|}
5.4646 \\
\end{tabular} & 1.4 & 12.9962 & 2.6 & .5151 & 2.2 & 0.85 & 678.3 & 49.0 & 2679.4 & 24.9 & 2680.2 & 23.4 & 80.2 & 23.4 & 99.9 \\
\hline Spot 17 & 122 & 211497 & 4.5 & 5.4486 & 1.3 & 13.0511 & 2.6 & .5157 & 2.3 & 0.87 & 681.1 & 49.6 & 2683.4 & 24.4 & 2685.1 & 20.9 & & 20.9 & 99.9 \\
\hline Spot 43 & 414 & 76907 & 0.6 & 5.4423 & 1.5 & 12.7840 & 2.5 & 5046 & 2.0 & 0.80 & 633.5 & 42.5 & 2663.9 & 23.2 & 2687.0 & 24.5 & & 24.5 & \\
\hline Spot 23 & 1131 & 2423 & 0.4 & 5.4420 & 1.0 & & 21 & & 1.8 & 0.87 & & & 466.6 & 19.2 & 2687.0 & 16.8 & & 16.8 & \\
\hline Spot 19 & 962 & 399420 & 0.4 & 29 & 1.0 & & 2.0 & & & 0.89 & 6 & 42.7 & 4.7 & 21.2 & 2689.8 & 0. & & 16.7 & \\
\hline Spot 7 & 202 & 5182 & 2.4 & 4282 & 1.0 & & 8 & & 0 & 0.85 & 698.2 & 34. & 94.2 & 17.4 & 2691.2 & 5.8 & & 15.8 & \\
\hline Spot 1 & 97 & 548 & 1.2 & .4278 & 1.1 & & 2.1 & & \begin{tabular}{|l|}
1.8 \\
\end{tabular} & 0.85 & 7.0 & 38 & 9.1 & 19.7 & 2691.4 & 8.1 & & \begin{tabular}{|l|}
18.1 \\
\end{tabular} & 07 \\
\hline Spot 9 & 180 & 4374 & 3.5 & 5.4268 & 1.2 & & 2.3 & & 2.0 & 0.87 & 2631.9 & 43. & 2665.8 & 22.1 & 2691.7 & 19.2 & & \begin{tabular}{|l|}
19.2 \\
\end{tabular} & JI. \\
\hline Spot 29 & 242 & 9562 & 4.0 & \begin{tabular}{|l|}
5.4189 \\
\end{tabular} & \begin{tabular}{|l|}
1.3 \\
\end{tabular} & 91 & 2.2 & 50 & \begin{tabular}{|l|}
1.8 \\
\end{tabular} & \begin{tabular}{|l|}
0.81 \\
\end{tabular} & \begin{tabular}{|l|}
2635.2 \\
\end{tabular} & 38.4 & 2668.7 & 20.7 & \begin{tabular}{|l|}
2694.1 \\
\end{tabular} & \begin{tabular}{|l|}
21.4 \\
\end{tabular} & 4.1 & \begin{tabular}{|l|}
21.4 \\
\end{tabular} & 97.8 \\
\hline Spot 40 & 206 & 2672 & 3.5 & 5.4050 & 1.2 & 62 & 2.4 & 251 & 2.1 & 0.87 & \begin{tabular}{|l|}
2720.9 \\
\end{tabular} & 45.7 & 2708.0 & 22.3 & 2698.3 & 19.0 & 8.3 & \begin{tabular}{|l|}
19.0 \\
\end{tabular} & 100.8 \\
\hline Spot 39 & 228 & 5109 & 1.4 & 5.3941 & \begin{tabular}{|l|}
1.1 \\
\end{tabular} & 12.3732 & 2.4 & .4841 & 2.2 & 0.90 & 544.9 & 46.0 & 2633.1 & 22.8 & 2701.7 & 17.5 & & 17.5 & 94.2 \\
\hline Spot 26 & 140 & 0727 & 1.2 & 5.3928 & 0.8 & & 1.7 & 5080 & 1.5 & 0.87 & 648.1 & 32.4 & 678.8 & 16.1 & \begin{tabular}{|l|}
2702.1 \\
\end{tabular} & 13. & & \begin{tabular}{|l|}
13.7 \\
\end{tabular} & 98 \\
\hline Spot 2 & 155 & 918 & 1.2 & 5.3877 & 1.2 & & 2.1 & & \begin{tabular}{|l|}
1.7 \\
\end{tabular} & 0.83 & 26 & 37.3 & 2.5 & 19.5 & 2703.6 & 19. & & \begin{tabular}{|l|}
19.2 \\
\end{tabular} & \\
\hline Spot 3 & & & 2.6 & 3762 & 1.4 & & 2.4 & & 10 & & & & & 22.5 & 2707.1 & 23.7 & & 23.7 & \\
\hline Spot 10 & 88 & & 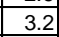 & & 1.1 & & 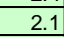 & & & & & & & 20.0 & & 17.8 & & \begin{tabular}{|l|}
17.8 \\
\end{tabular} & \\
\hline Spo & 149 & & 3.6 & 5.3744 & 1.1 & & 1.9 & & 1.5 & 0.81 & & 33 & & 17.7 & \begin{tabular}{|l|}
2707.7 \\
\end{tabular} & 18.1 & & \begin{tabular}{|l|}
18.1 \\
\end{tabular} & 100 \\
\hline Spot 38 & 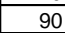 & 037 & 0 & \begin{tabular}{|l|}
5.3728 \\
\end{tabular} & 1.4 & & 2.7 & & \begin{tabular}{|l|}
2.4 \\
\end{tabular} & 0.86 & 2662.9 & 51. & 38.7 & 25.9 & \begin{tabular}{|l|}
2708.2 \\
\end{tabular} & 22.8 & & \begin{tabular}{|l|}
22.8 \\
\end{tabular} & \\
\hline Spot 28 & 257 & 623 & 3.0 & 5.3680 & 1.4 & 74 & 2.2 & 89 & 1.8 & 0.79 & 2565.9 & 37.2 & 2647.0 & 20.9 & \begin{tabular}{|l|}
2709.7 \\
\end{tabular} & 22.4 & & \begin{tabular}{|l|}
22.4 \\
\end{tabular} & 94.7 \\
\hline Spot 20 & 296 & 154 & 1.1 & 5.3606 & 1.1 & & 3.0 & & 2.8 & 0.93 & \begin{tabular}{|l|}
2521.7 \\
\end{tabular} & 57.5 & 2628.6 & 28.0 & 2711.9 & 18.6 & & \begin{tabular}{|l|}
18.6 \\
\end{tabular} & 93.0 \\
\hline Spot 18 & 100 & 9102 & 1.2 & \begin{tabular}{|l|}
5.3390 \\
\end{tabular} & 1.2 & 12.8965 & 2.2 & 4994 & 1.8 & 0.83 & 2611.1 & 38.7 & 672.1 & 20.4 & 2718.6 & 19.8 & & 19.8 & 96 \\
\hline Spot 6 & 195 & 1445 & 1.8 & 5.3283 & 1.4 & 12.8720 & 2.2 & 4974 & 1.7 & 0.76 & 2602.7 & 35. & 2670.3 & 20.7 & 2721.9 & 23.5 & & 23.5 & \\
\hline Spot 24 & 359 & 513 & 1.0 & 5.3236 & 1.0 & 13.3574 & 2.1 & 157 & 1.8 & 0.87 & 2681.1 & 40.0 & 2705.3 & 19.8 & 2723.3 & 16.9 & & 16.9 & 98. \\
\hline Spot 37 & 273 & 371 & 0 & 5.3210 & 1.2 & & 2.7 & & 2.5 & 0.90 & 2673.4 & 53. & 2702.4 & 25.8 & 2724.2 & 19.4 & & \begin{tabular}{|l|}
19.4 \\
\end{tabular} & \\
\hline Spot 33 & & & 3 & 5.2969 & 1.2 & & 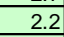 & & 1.8 & 0.82 & 26 & 3 & 2689.5 & 20.4 & 27 & 20.1 & & 20.1 & \\
\hline Spot 42 & 00 & 965 & .1 & 5.2435 & 1.3 & & 2.7 & & 2.3 & 0.87 & 2584.6 & 49. & 2677.4 & 25.5 & 2748.3 & 22.2 & & 22.2 & \\
\hline Spot 4 & 330 & 286137 & 1.4 & 5.2258 & 1.2 & & 1.9 & & 1. & 0.75 & 2733.6 & 31. & 2745.3 & 17.6 & 2753.9 & 20.2 & & 20.2 & 9 \\
\hline Spot 14 & 1025 & 1382 & 4.4 & 5.1958 & 1.1 & 12.8 & 1.9 & 825 & 1.5 & 0.81 & 2538.4 & 32. & 2665.4 & 17.7 & 2763.3 & 18.0 & & 18.0 & 1 \\
\hline Spot 12 & 693 & 4083 & 1.2 & 5.1695 & 1.1 & 14.1466 & 1.8 & & 1.4 & 0.78 & 2743.1 & 30.6 & 2759.6 & 16.6 & 2771.7 & 18.0 & 2771.7 & 18.0 & 99. \\
\hline Spot 35 & 1078 & 194712 & 1.4 & \begin{tabular}{|l|}
5.1279 \\
\end{tabular} & 1.1 & 13.2342 & 2.6 & 4922 & 2.3 & 0.90 & 2580.2 & 49.3 & 2696.5 & 24.4 & 2784.9 & 18.8 & & 18.8 & 92.6 \\
\hline Spot 15 & 359 & 47897 & 20.7 & \begin{tabular}{|l|}
5.0964 \\
\end{tabular} & 1.2 & 13.3247 & 2.0 & 0.4925 & 1.7 & 0.82 & 2581.6 & 35.6 & 2702.9 & 19.4 & 2795.0 & 19.3 & 5.0 & \begin{tabular}{|l|}
19.3 \\
\end{tabular} & 92.4 \\
\hline Spot 34 & 1564 & 671769 & 6.4 & 5.0793 & 1.6 & 14.2524 & 3.5 & 0.5250 & 3.1 & 0.89 & 2720.5 & 69.2 & 2766.6 & 33.2 & 2800.5 & 26.0 & 2800.5 & 26.0 & 97 \\
\hline Spot 47 & 37 & 29025 & 0.2 & 5.0245 & 1.3 & 13.4839 & 2.5 & 0.4914 & 2.1 & 0.84 & 2576.6 & 44.3 & 2714.2 & 23.5 & 2818.2 & 21.9 & & 21.9 & 91. \\
\hline Spot 46 & 27 & 926 & 0.5 & \begin{tabular}{|l|}
4.8884 \\
\end{tabular} & 1.4 & 13.6248 & 2.3 & & 1.9 & 0.80 & 2540.6 & 39.1 & 2724.0 & 22.1 & 2863.0 & 23.0 & & 23.0 & 88. \\
\hline Spot 22 & 166 & 4842 & 1.2 & \begin{tabular}{|l|}
4.8883 \\
\end{tabular} & 1.2 & 12.9817 & 2.3 & 0.4602 & 2.0 & 0.86 & \begin{tabular}{|l|}
2440.7 \\
\end{tabular} & 41.0 & 2678.3 & 22.1 & 2863.0 & 19.6 & 2863.0 & 19.6 & 85. \\
\hline
\end{tabular}




\section{Shelbyville Analysis (sorted by best age)}

\begin{tabular}{|c|c|c|c|c|c|c|c|c|c|c|c|c|c|c|c|c|c|c|c|}
\hline & & & & & \multicolumn{3}{|c|}{ Isotope ratios } & & & & & & \multicolumn{3}{|c|}{ Apparent ages (Ma) } & & & & \\
\hline & U & $06 \mathrm{~Pb}$ & & & \pm & & \pm & 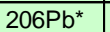 & \pm & ror & & \pm & & $I$ & & $I$ & e & I & CUIC \\
\hline & (ppm) & $204 \mathrm{~Pb}$ & & $207 \mathrm{~Pb}^{*}$ & $(\%)$ & $235 U^{*}$ & $(\%)$ & $238 \mathrm{U}$ & (\%) & \begin{tabular}{|l|} 
corr. \\
\end{tabular} & $238 U^{*}$ & $(\mathrm{Ma})$ & & (Ma) & $207 \mathrm{~Pb}^{*}$ & (Ma) & (Ma) & (Ma) & $(\%)$ \\
\hline Spot 93 & 138 & 94995 & 1.2 & 12.2433 & 1.4 & 2.3364 & 2.7 & 0.2075 & 2.3 & 0.85 & 1215.3 & 25.5 & 1223.4 & 19.2 & 1237.8 & 27.8 & 37.8 & 27.8 & 8.2 \\
\hline Spot 78 & 106 & 42778 & 1.6 & 12.1154 & 1.7 & 2.4331 & 3.0 & 2138 & 2.5 & 0.83 & 1249.0 & 28.4 & 1252.4 & 21.6 & 1258.4 & 32.7 & & 32.7 & 99.3 \\
\hline Spot 58 & 160 & 65090 & 2.0 & 11.8440 & 1.7 & 2.5655 & 3.0 & 2204 & 2.5 & 0.83 & 1283.9 & 29.4 & 1290.9 & 22.2 & 1302.5 & 32.6 & & 32.6 & 98.6 \\
\hline Spot 59 & 47 & 128901 & 2.3 & 5.5600 & 1.3 & 12.2326 & 2.2 & & 1.8 & 0.80 & 2584.8 & 38.4 & 2622.4 & 21.1 & 2651.5 & 22.2 & & 22.2 & 97.5 \\
\hline Spot 89 & 229 & 39460 & 15.5 & 5.4564 & 1.1 & 12.8314 & 2.4 & 078 & 2.2 & 0.90 & 2647.2 & 47.5 & 2667.3 & 22.9 & 2682.7 & 17.7 & 32.7 & 17.7 & 98.7 \\
\hline Spot 60 & 41 & 43550 & 2.5 & 5.4524 & 1.5 & 12.8182 & 2.5 & 069 & 2.0 & 0.80 & 2643.4 & 43.0 & 2666.4 & 23.3 & 2683.9 & 24.4 & 33.9 & 24.4 & 98.5 \\
\hline Spot 54 & 94 & 143329 & 1.8 & .4511 & 1.4 & 12.8727 & 2.7 & 89 & 2.3 & \begin{tabular}{|l|}
0.85 \\
\end{tabular} & 2652.0 & 49.4 & 2670.4 & 25.2 & 2684.3 & 23.4 & & 23.4 & 8.8 \\
\hline Spot 91 & 399 & 6971 & 4.8 & 5.4470 & 1.5 & 13.0 & 2.4 & & 1.9 & 78 & 268 & 41.5 & 2684.7 & 22.8 & 2685.5 & 24.8 & & 24.8 & 9.9 \\
\hline $\mathrm{Spc}$ & 284 & 802015 & 2.2 & 91 & 1.2 & 12.5 & 2.0 & 66 & 1.6 & 80 & $25 \mathrm{C}$ & 35.0 & 2649.4 & 19.3 & 2687.9 & 20.4 & & 20.4 & 96.7 \\
\hline $\mathrm{Spc}$ & 60 & & 3.1 & & 1.4 & 12. & 2.7 & & 2.4 & & & & & 25.8 & & 22.9 & & 22.9 & 9.1 \\
\hline Spot 70 & 225 & 27 & 1.0 & 12 & 1.2 & 13.1 & 2.3 & 59 & 1.9 & 85 & 268 & 42.6 & 2688.4 & 21.5 & 3.4 & 19.6 & 3.4 & 19.6 & 99.6 \\
\hline & 133 & & 4.0 & & 1.5 & 12.8 & 2.5 & & 2.0 & & & & & 23.6 & & 24.2 & & 24.2 & 7.7 \\
\hline Spc & 194 & 248684 & 1.7 & 83 & 1.2 & 12.9206 & 2.4 & 077 & 2.1 & 88 & 2647.0 & 46.7 & 2673.9 & 23.1 & 2694.3 & 19.3 & 4.3 & 19.3 & 98.2 \\
\hline & 107 & & & & 1.3 & & & & 1.7 & & & & & 20.7 & & 22.3 & & 22.3 & 3.4 \\
\hline Spot 79 & 421 & 48292 & 0.8 & 20 & 1.3 & 13.2 & 2.3 & 200 & 1.9 & \begin{tabular}{|l|}
0.83 \\
\end{tabular} & 269 & 41.8 & 2699.1 & 21.7 & 2699.2 & 21.3 & 9.2 & 21.3 & 100.0 \\
\hline 51 & 150 & & 2.0 & & 1.2 & 12.6 & 2.6 & & 2.3 & 89 & & 49.5 & & 24.6 & & 20.0 & & 20.0 & 96.4 \\
\hline $\mathrm{Spc}$ & 33 & 81 & 3.2 & & 1.3 & 13.1 & 2.3 & & 1.9 & \begin{tabular}{|l|}
0.82 \\
\end{tabular} & 266 & 41.7 & 2687.0 & 22.0 & .6 & 22.3 & & 22.3 & 98.8 \\
\hline 66 & 94 & & 3.9 & & 1.3 & 8 & 2.8 & & 2.5 & & & 54.6 & & 26.3 & & 20.7 & & 20.7 & 9.4 \\
\hline $\mathrm{Spc}$ & 230 & 65 & 1.4 & & 1.3 & 13.1 & 2.3 & & 1.9 & 0.83 & 267 & 41.4 & 1.5 & 21.6 & 4.1 & 21.3 & & 21.3 & 98.9 \\
\hline 57 & 87 & & 3.4 & & 1.6 & 13.3 & 2.6 & & 2.1 & 0 & & 46.4 & & 25.0 & & 26.4 & & 26.4 & 99.7 \\
\hline Spot 56 & 161 & 19 & 1.5 & & 1.3 & 13.4 & 2.8 & & 2.5 & \begin{tabular}{|l|}
0.88 \\
\end{tabular} & 271 & 54.6 & & 26.3 & & 21.4 & & 21.4 & 100.4 \\
\hline $\mathrm{Spc}$ & 88 & & 4.1 & & 1.2 & 13. & 2.4 & & 2.0 & 86 & 26 & 44.3 & & 22.2 & & 19.7 & & 19.7 & 98.7 \\
\hline $\mathrm{Spc}$ & 367 & & 1.8 & & 0.9 & 13.6 & 1.9 & & 1.6 & 7 & 27 & 36.0 & & 17.5 & & 15.1 & & 15.1 & 101.1 \\
\hline $\mathrm{Spc}$ & 103 & & 3.8 & & 1.5 & 13.0 & 2.5 & & 2.1 & 81 & 26 & 44.7 & & 23.8 & & 24.2 & & 24.2 & 97.6 \\
\hline & 88 & & 2.8 & & 1.3 & 8 & 2.4 & & 2.0 & & 272 & & & 22.7 & & 21.9 & & 9 & .5 \\
\hline 72 & 89 & & 3.5 & & 1.3 & 30 & 2.2 & & 1.8 & 31 & 26 & 8 & & 21.3 & & 22.0 & & 22.0 & 8.9 \\
\hline 76 & 224 & & 1.4 & & 1.3 & 13.6 & 2.3 & & 1.9 & 2 & 27 & 42.6 & & 22.1 & & 22.2 & & 22.2 & 100.5 \\
\hline 71 & 247 & & 5 & & 1.2 & 13.4 & 2.2 & & 1.8 & 3 & & 39.9 & & 20.6 & & 19.9 & & 19.9 & 99.1 \\
\hline & & & & & 1.7 & & & & 2.4 & & & & & 27.7 & & 6 & & 6 & .7 \\
\hline $\mathrm{Spc}$ & 712 & & 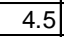 & & 1.5 & 4 & 2.7 & & 2.2 & & & & & 25.1 & & 25.1 & & 25.1 & 5.8 \\
\hline & 6 & & & & 1.4 & & 2 & & 2.4 & & & & & 26.5 & & 23.6 & & 23.6 & 3 \\
\hline Spot 99 & 461 & & & & 2.0 & 13.3 & 4.3 & & 3.8 & 9 & 26 & & & 40.7 & & 32.8 & & 32.8 & 8.0 \\
\hline Spot 85 & 971 & 80 & 7 & & 1.1 & 13.4 & 2.2 & & 1.9 & 36 & 0 & 41.7 & .9 & 20.9 & 5.2 & 18.5 & .2 & 18.5 & 7.8 \\
\hline $\mathrm{Spc}$ & 139 & & 2.4 & & 1.7 & 13.6 & 3.2 & & 2.7 & 4 & 27 & 58.9 & 9.0 & 29.8 & .2 & 27.9 & & 27.9 & 9.4 \\
\hline Spot 100 & 499 & 92 & 8.0 & 96 & 1.2 & 12.5 & 3.3 & 06 & 3.1 & \begin{tabular}{|l|}
0.94 \\
\end{tabular} & 2529.9 & 64.5 & 6.6 & 31.0 & 7.0 & 19.0 & 7.0 & 19.0 & 2.4 \\
\hline Spot 75 & 660 & & & & 1.3 & 12.6 & 2.3 & & 2.0 & \begin{tabular}{|l|}
0.84 \\
\end{tabular} & & & & 22.0 & & 20.9 & & 20.9 & 22.6 \\
\hline Spot 98 & 228 & 31 & 2.3 & 48 & 1.4 & 13.2 & 2.2 & & 1.7 & \begin{tabular}{|l|}
0.76 \\
\end{tabular} & 263 & 36.3 & 5.7 & 20.9 & 4.8 & 23.7 & 4.8 & 23.7 & 95.8 \\
\hline Spot 74 & 287 & & & & 1.3 & 13.2 & 2.5 & & 2.2 & & & & & 24.0 & & 21.1 & & 21.1 & 5.9 \\
\hline Spot 90 & 67 & 99 & 2.1 & & 1.7 & 13.7 & 2.4 & 36 & 1.7 & \begin{tabular}{|l|}
0.71 \\
\end{tabular} & 2714.4 & 38.3 & 3.3 & 23.1 & 2747.2 & 28.4 & 7.2 & 28.4 & 98.8 \\
\hline Spot 92 & 466 & 7877 & 5.6 & & 1.5 & 13.3075 & 2.8 & & 2.4 & \begin{tabular}{|l|}
0.85 \\
\end{tabular} & 26 & 51.9 & 2701.7 & 26.6 & 2748.8 & 24.3 & 8.8 & 24.3 & 96.0 \\
\hline Spot 63 & 116 & 241164 & 1.4 & 301 & 1.1 & 13.6086 & 2.0 & & 1.7 & \begin{tabular}{|l|}
0.83 \\
\end{tabular} & 2683.1 & 36.6 & 2722.9 & 19.1 & 2752.5 & 18.7 & 2.5 & 18.7 & 97.5 \\
\hline Spot 62 & 241 & 936 & 2.6 & & 1.4 & 13.6918 & 2.6 & & 2.2 & \begin{tabular}{|l|}
0.85 \\
\end{tabular} & 265 & 49.5 & 2728.6 & 25.1 & 3.1 & 23.1 & 3.1 & 23.1 & 97.9 \\
\hline Spot 80 & 219 & 355549 & 2.1 & & 1.3 & 14.0 & 2.7 & & 2.3 & \begin{tabular}{|l|}
0.87 \\
\end{tabular} & 2746.1 & 51.4 & 2750.5 & 25.1 & 2753.7 & 21.7 & 3.7 & 21.7 & 99.7 \\
\hline Spot 73 & 250 & & 2.1 & & 1.4 & 13.9139 & 2.5 & 61 & 2.1 & \begin{tabular}{|l|}
0.83 \\
\end{tabular} & 2725.0 & 46.7 & 2743.9 & 23.9 & 2757.8 & 22.8 & 7.8 & 22.8 & 98.8 \\
\hline Spot 69 & 228 & 114565 & 2.0 & & 1.0 & 13.6904 & 1.9 & & 1.6 & \begin{tabular}{|l|}
0.84 \\
\end{tabular} & 2688.3 & 34.8 & 2728.5 & 17.8 & 2758.4 & 16.8 & 58.4 & 16.8 & 97.5 \\
\hline Spot 95 & 514 & 77215 & 5.3 & & 1.1 & 13.4337 & 2.7 & & 2.4 & \begin{tabular}{|l|}
0.91 \\
\end{tabular} & 2646.5 & 52.4 & & 25.2 & & 18.5 & & 18.5 & 95.9 \\
\hline Spot 83 & 586 & 186875 & 19.8 & & 1.1 & 14.0036 & 2.3 & 274 & 2.0 & \begin{tabular}{|l|}
0.88 \\
\end{tabular} & 2730.3 & 44.9 & 2750.0 & 21.7 & 2764.4 & 17.6 & 4.4 & 17.6 & 98.8 \\
\hline & 639 & & 5.5 & & 1.2 & 14.0224 & 2.6 & 084 & 2.3 & \begin{tabular}{|l|}
0.89 \\
\end{tabular} & 2649.8 & 50.9 & 2751.2 & 25.0 & 2826.5 & 19.7 & 2826.5 & 19.7 & 93.7 \\
\hline Spot 77 & 153 & 21555 & 4.1 & 4.7129 & 1.4 & 15.4446 & 2.4 & 0.5279 & 2.0 & \begin{tabular}{|l|}
0.81 \\
\end{tabular} & 2732.7 & 43.9 & 2843.1 & 23.2 & 2922.3 & 23.1 & 2922.3 & 23.1 & 93.5 \\
\hline
\end{tabular}




\section{Charleston Analysis (sorted by best age)}

\begin{tabular}{|c|c|c|c|c|c|c|c|c|c|c|c|c|c|c|c|c|c|c|c|}
\hline & & & & & & Isotope ra & atios & & & & & & Apparen & t age & $\mathrm{S}(\mathrm{Ma})$ & & & & \\
\hline \begin{tabular}{|l|} 
Analysis \\
\end{tabular} & $\bar{U}$ & $206 \mathrm{~Pb}$ & Th & $6 \mathrm{~Pb}^{*}$ & \pm & 207Pb* & \pm & $06 \mathrm{~Pb}^{*}$ & \pm & enror & $6 \mathrm{~Pb}^{*}$ & \pm & $07 \mathrm{~Pb}^{*}$ & \pm & $06 \mathrm{~Pb}^{*}$ & \pm & ge & $t$ & Conc \\
\hline & (ppm) & $204 \mathrm{~Pb}$ & & $207 \mathrm{~Pb}^{\star}$ & $(\%)$ & $235 \mathrm{U}^{*}$ & (\%) & $238 \mathrm{U}$ & (\%) & corr. & $238 U^{*}$ & (Ma) & $235 \mathrm{U}$ & (Ma) & $207 \mathrm{~Pb}^{\star}$ & (Ma) & (Ma) & (Ma) & (\%) \\
\hline & & & & & & & & & & & & & & & & & & & \\
\hline Spot & 981 & 10804 & 2.2 & 5.7320 & 1.4 & 7530 & 3.0 & 4055 & 2.6 & 88 & 194.3 & 3.7 & 1.8 & 7.4 & 00. & 3.7 & 9 & 3.7 & 4.4 \\
\hline Spot 51 & 906 & 100344 & 0.7 & 1115 & 1.5 & & 25 & 4991 & 2.0 & 79 & 2609.8 & 42.3 & 08.1 & 20 & & 25.0 & & 5.0 & 00.1 \\
\hline Spot 75 & 4927 & 94250 & 53.8 & 5.6642 & 1.2 & 9.9592 & 25 & 409 & 2.2 & 0.89 & 2210. & \begin{tabular}{|l|l}
41.7 \\
\end{tabular} & 24310 & 232 & & 19.2 & & 19.2 & 84.4 \\
\hline Spot 74 & 111 & 149300 & 0.4 & 5.6587 & 1.5 & 11.9472 & 26 & \begin{tabular}{|l|}
0.4903 \\
\end{tabular} & 2.1 & 0.83 & 2572.1 & 45.4 & 2600.3 & 24.2 & 522.3 & 24.2 & 622.3 & 24.2 & 98.1 \\
\hline Spot 99 & 724 & 8223519 & 3.6 & 5.6497 & 1.3 & 12.6172 & 3.0 & \begin{tabular}{|l|}
0.5170 \\
\end{tabular} & 2.7 & 0.90 & 2686.4 & 58.4 & 2651.5 & 27.9 & & 21.8 & & 21.8 & 102.3 \\
\hline Spot 52 & 682 & 221282 & 6.2 & 5.5896 & 1.2 & & 26 & \begin{tabular}{|l|}
0.4830 \\
\end{tabular} & 2.3 & 0.89 & 2540. & 49.0 & 2597.8 & 24.6 & 42.7 & 20.0 & 42.7 & 00 & nct \\
\hline Spot 80 & 128 & 79885 & 0.8 & 5.5773 & 1.5 & 12.5223 & 26 & 0.5065 & 2.2 & 0.83 & 641.8 & \begin{tabular}{|l|}
47.7 \\
\end{tabular} & 2644.4 & 24.9 & 2646.4 & 24.3 & 646.4 & 24.3 & 99.8 \\
\hline Spot 97 & 375 & 174065 & 3.1 & 5.5656 & 0.9 & 12.2288 & 2.2 & \begin{tabular}{|l|}
0.4936 \\
\end{tabular} & 2.1 & 0.92 & 2586.3 & 43.8 & 2622.1 & 20.9 & 2649.9 & 14.3 & 9.9 & 14.3 & 97.6 \\
\hline Spot 90 & 63 & 65622 & 1.4 & 5.5484 & 1.4 & & 2.4 & & 2.0 & 0.82 & ת & 42.1 & & 22.4 & & 22.7 & & 22.7 & \\
\hline Spot 93 & 101 & 45279 & 1.3 & 5.5299 & 1.9 & 12.6294 & 3.0 & \begin{tabular}{|c|}
0.5065 \\
\end{tabular} & 2.4 & 0.78 & 2641.8 & 51.0 & 2652.4 & 28.3 & 2660.5 & 31.1 & 60.5 & 31.1 & 99.3 \\
\hline Spot 53 & 1761 & 74602 & 1.2 & 5.5195 & 1.2 & 10.6477 & 24 & \begin{tabular}{|l|}
0.4262 \\
\end{tabular} & 2.1 & 0.87 & 2288.7 & \begin{tabular}{|l|}
40.4 \\
\end{tabular} & 2492.9 & 22.3 & 3.7 & 19.4 & 3.7 & 19.4 & 85.9 \\
\hline Spot 62 & 200 & 3636 & 1.5 & 5164 & 1.3 & & 2.3 & 5051 & 1.9 & 0.82 & 2635.7 & \begin{tabular}{|l|}
40.7 \\
\end{tabular} & 2652.1 & 21.5 & & 21.5 & & 1.5 & 10.5 \\
\hline Spot 60 & 147 & 8003 & 0.8 & 5.5059 & 1.6 & 12.4238 & 2.4 & 4961 & 1.8 & \begin{tabular}{|l|}
0.74 \\
\end{tabular} & 2597. & 37.5 & 2637.0 & 22.1 & 2667.7 & 26.0 & 87.7 & 26.0 & 97.4 \\
\hline Spot 57 & 318 & 171725 & 0.7 & 5.4990 & 1.4 & 12 & 23 & \begin{tabular}{|l|}
0.5076 \\
\end{tabular} & 1.8 & 0.81 & 2646.3 & 40.0 & 2659.6 & 21.5 & 2669.8 & 22.4 & 9.8 & 22.4 & 99.1 \\
\hline Spot 84 & 78 & 2429 & 12.0 & 5.4927 & 1.5 & & 25 & 47 & 2.0 & 0.81 & 2416.3 & \begin{tabular}{|l|}
40.9 \\
\end{tabular} & 5557.6 & 23.4 & 1.7 & 24.2 & & 24.2 & 90.4 \\
\hline Spot 96 & 22 & 50886 & \begin{tabular}{|l|}
47.1 \\
\end{tabular} & 5.4798 & 1.5 & & 3.3 & 0.0 & 2.9 & 0.89 & 2756.7 & \begin{tabular}{|l|l|}
64.7 \\
\end{tabular} & 770.1 & 30.8 & & 25.0 & & 25.0 & 03.0 \\
\hline Spot 68 & 133 & 160390 & 0.9 & 5.4756 & 1.5 & & 3.3 & 5097 & 2.9 & 0.89 & 2655.2 & 63.5 & 2667.6 & \begin{tabular}{|l|}
30.8 \\
\end{tabular} & 76.9 & 24.3 & 6.9 & 24.3 & 99.2 \\
\hline Spot 58 & 521 & 2251 & 1.3 & 5.4730 & 1.1 & & 2.2 & 4844 & 1.9 & 0.86 & 546 & 40.2 & 20.2 & 20.8 & 7.6 & 18.6 & 7.6 & 18.6 & 95.1 \\
\hline Spot 98 & 190 & 6755 & 1.2 & 5.4651 & 1.4 & & 2.7 & 4735 & 2.3 & 0.86 & 498.9 & \begin{tabular}{|l|}
48.1 \\
\end{tabular} & 2600.2 & 25.3 & 2680.1 & 22.9 & 80.1 & 22.9 & 93.2 \\
\hline Spot 91 & 192 & 5846 & 1.5 & 5.4631 & 1.4 & 80 & 26 & 5075 & 2.2 & 0.85 & 645.9 & \begin{tabular}{|l|}
48.3 \\
\end{tabular} & 2665.6 & 24.8 & 2680.6 & 23.2 & 80.6 & 23.2 & 98.7 \\
\hline Spot 61 & 620 & 63 & 19.3 & 5.4 & .5 & & 4.0 & 0 & 3.6 & \begin{tabular}{|l|}
0.92 \\
\end{tabular} & 24 & $\begin{array}{ll}74.3 \\
\end{array}$ & 2582.3 & 37.0 & 29 & 25.6 & & 25.6 & 91.5 \\
\hline Spot 70 & 70 & 356 & $\overline{1.4}$ & 5 & .7 & & 3.0 & 5 & 2.5 & (2) & 533 & 21 & & 28. & & 27.8 & & 27. & $\overline{94.4}$ \\
\hline Spot 55 & 1209 & 5663 & 2.8 & 5.4504 & 1.2 & & 29 & 5101 & 2.6 & 0.91 & 000 & 56.9 & 672.7 & 7.2 & 4.5 & 20.3 & 4.5 & 20.3 & 99.0 \\
\hline Spot 81 & 101 & 121398 & 2.5 & 5.4190 & 1.5 & & 28 & & 2.3 & 0.85 & 2656.8 & 50.8 & 2678.0 & 26.0 & & 24.3 & & 24.3 & 98.6 \\
\hline Spot 94 & 81 & 9953 & 2.1 & 540 & .5 & & 3.3 & & 2.9 & (2) & 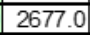 & 63.9 & 80 & 0.8 & & 24.1 & & 24.1 & 99.2 \\
\hline Spot 82 & 135 & 1236256 & 3.0 & 3890 & 1.2 & & 2.2 & 5339 & 1.9 & 0.84 & 2757.8 & \begin{tabular}{|l|l|}
41.7 \\
\end{tabular} & 726.4 & 21.0 & B.2 & 20.1 & 3.2 & 20.1 & 102.0 \\
\hline Spot 63 & 50 & 292035 & 3.3 & 3868 & 1.3 & & 26 & & 2.3 & 0.88 & 2718 & \begin{tabular}{|l|}
50.7 \\
\end{tabular} & & \begin{tabular}{|l|}
24.7 \\
\end{tabular} & & 20.9 & & 20.9 & 00.5 \\
\hline Spot 100 & 37 & 2739 & 0.2 & 38 & 1.3 & & 3.1 & 4808 & 2.8 & 0.90 & .9 & 57.7 & 8.5 & 8.8 & & 22.1 & & 22.1 & 93.6 \\
\hline Spot 85 & 851 & 380378 & 5.5 & 3813 & 1.5 & 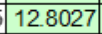 & 3.3 & 4997 & 3.0 & 0.90 & 612. & \begin{tabular}{|l|l|}
63.7 \\
\end{tabular} & 665.2 & 31.2 & 5.6 & 24.4 & 5.6 & 24.4 & 96.6 \\
\hline Spot 65 & & & 8 & 85 & 1.2 & & 25 & & 2.1 & 0 & & \begin{tabular}{|l|} 
\\
\end{tabular} & & 23.3 & & 20.5 & & 20.5 & 99.5 \\
\hline 56 & & 747 & 2.8 & 50 & 1.0 & & 2.2 & 5003 & 1.9 & D & 261 & 40.9 & 7.5 & 20.5 & & 17.3 & & 17.3 & 966 \\
\hline Spot 66 & 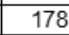 & 013 & 1.5 & 3691 & 1.5 & & 2.9 & 29 & 2.5 & 0.86 & 49 & 51.6 & 5.6 & 27.1 & & 24. & & 24.1 & 92.1 \\
\hline Spot 64 & 9 & 660 & 1.7 & 3664 & 1.3 & & 2.2 & 77 & 1.8 & 0 & 251 & 37.0 & 625.5 & 20.4 & & 20.7 & & 20.7 & 92.9 \\
\hline Spot 86 & & 54 & 2 & & 12 & & 2.1 & & 1.7 & & 26 & & & 198 & & 19.3 & & 19.3 & 07 \\
\hline Spot 87 & 4 & 5788 & 8 & 3248 & .2 & & 23 & 5317 & 2.0 & 0.86 & 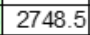 & 43.9 & 2733.8 & \begin{tabular}{|l|l|}
21.7 \\
\end{tabular} & 3.0 & 19.5 & & 19.5 & 00. \\
\hline Spot 73 & 140 & 841 & .0 & 5.2907 & 1.3 & 1 & 25 & 0.5511 & 2.2 & 0.86 & 82 & 50.1 & 2773.9 & 24.1 & 3.6 & 21.4 & 3.6 & 21.4 & 103.5 \\
\hline Spot 69 & & & & & 1.0 & & 2.5 & & 2.3 & 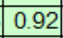 & & 9.8 & & 3.4 & & 6.1 & & 16.1 & 070 \\
\hline Spot 88 & & 49 & 8 & 2654 & 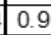 & & 2.3 & 5456 & 2.1 & 32 & 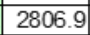 & 3.7 & 9.0 & 22.0 & & 14.8 & & \begin{tabular}{|l|l|}
14.8 \\
\end{tabular} & 102.4 \\
\hline Spot 83 & 754 & 751 & 5.7 & 5.2576 & 1.8 & 36 & 3.4 & \begin{tabular}{|l|}
0.4764 \\
\end{tabular} & 2.8 & 0.84 & 2511.6 & 59.0 & 2642.2 & 31.6 & 2743.9 & 29.6 & 43.9 & 29.6 & 91.5 \\
\hline Spot 79 & 862 & & 10.5 & & 1.1 & & 26 & & 2.4 & 0.90 & 24 & 47.5 & 2598.8 & 24.5 & & 18.6 & & 18.6 & 87.7 \\
\hline Spot 95 & 71 & & 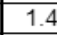 & 50 & & & 25 & & 200 & \begin{tabular}{|l|}
084 \\
\end{tabular} & & 45.3 & & & & 22.1 & & 22.1 & \\
\hline Spot 77 & 188 & 3757 & 0.4 & 5.2327 & 1.6 & 01 & 3.2 & 0.4991 & 2.8 & 0.87 & 2609.8 & 60.9 & 2690.5 & \begin{tabular}{|l|}
30.7 \\
\end{tabular} & 2751.7 & 26.0 & 51.7 & 26.0 & 94.8 \\
\hline Spot 71 & 222 & 192798 & 1.5 & 5.0883 & 1.5 & & 2.4 & 0.5165 & 1.9 & 0.78 & \begin{tabular}{|l|}
2684.3 \\
\end{tabular} & 40.9 & \begin{tabular}{|l|l}
2749.4 \\
\end{tabular} & 22.5 & & 24.2 & & 24.2 & 96. \\
\hline & & & & & & & 2.0 & & 1.7 & & & 38.8 & 92.1 & $F_{2}$ & & \begin{tabular}{|l|l} 
& 15.9 \\
\end{tabular} & & 1 & \\
\hline Spot 54 & 116 & 1965 & 0.9 & 5.0266 & 27 & 13.9152 & 3.3 & \begin{tabular}{|l|}
0.5073 \\
\end{tabular} & 1.8 & 0.56 & \begin{tabular}{|l|}
2645.1 \\
\end{tabular} & 39.9 & 2744.0 & 30.9 & 2817.5 & \begin{tabular}{|l|l}
44.0 \\
\end{tabular} & 817.5 & 44.0 & 93.9 \\
\hline Spot 89 & 660 & 111798 & 1.0 & 4.9578 & 1.5 & 14.9336 & 3.1 & 0.5370 & 2.7 & 0.87 & \begin{tabular}{|l|}
2770.8 \\
\end{tabular} & 60.1 & 2811.0 & 29.3 & 2840.0 & 25.1 & 840.0 & 25.1 & 97.6 \\
\hline Spot 59 & 194 & 386 & & 346 & 2.0 & & 3.7 & 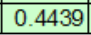 & 3. & 0.84 & & 62.2 & 5.4 & 0 & & 32 & 847.7 & 32. & 83. \\
\hline
\end{tabular}

